\title{
Het autonome zenuwstelsel bij borderline hypertensie : speelt het autonome zenuwstelsel een rol in de genese van essentiele hypertensie? : een vergelijkend onderzoek bij borderline hypertensieve en normotensieve controle personen van gelijke leeftijd
}

Citation for published version (APA):

Henquet, J-W. (1980). Het autonome zenuwstelsel bij borderline hypertensie : speelt het autonome zenuwstelsel een rol in de genese van essentiele hypertensie? : een vergelijkend onderzoek bij borderline hypertensieve en normotensieve controle personen van gelijke leeftijd. [Doctoral Thesis, Maastricht University]. Rijksuniversiteit Limburg. https://doi.org/10.26481/dis.19801121jh

Document status and date:

Published: 01/01/1980

DOI:

10.26481/dis.19801121jh

Document Version:

Publisher's PDF, also known as Version of record

Please check the document version of this publication:

- A submitted manuscript is the version of the article upon submission and before peer-review. There can be important differences between the submitted version and the official published version of record. People interested in the research are advised to contact the author for the final version of the publication, or visit the DOI to the publisher's website.

- The final author version and the galley proof are versions of the publication after peer review.

- The final published version features the final layout of the paper including the volume, issue and page numbers.

Link to publication

\footnotetext{
General rights rights.

- You may freely distribute the URL identifying the publication in the public portal. please follow below link for the End User Agreement:

www.umlib.nl/taverne-license

Take down policy

If you believe that this document breaches copyright please contact us at:

repository@maastrichtuniversity.nl

providing details and we will investigate your claim.
}

Copyright and moral rights for the publications made accessible in the public portal are retained by the authors and/or other copyright owners and it is a condition of accessing publications that users recognise and abide by the legal requirements associated with these

- Users may download and print one copy of any publication from the public portal for the purpose of private study or research.

- You may not further distribute the material or use it for any profit-making activity or commercial gain

If the publication is distributed under the terms of Article $25 \mathrm{fa}$ of the Dutch Copyright Act, indicated by the "Taverne" license above,

Download date: 26 Apr. 2023 


\section{Het autonome zenuwstelsel bij borderline hypertensie}

Speelt het autonome zenuwstelsel een rol in de genese van essentiële hypertensie? Een vergelijkend onderzoek bij borderline

hypertensieve en normotensieve controle personen van gelijke leeftijd.

(with a summary in English)

J.W. Henquet 


\section{Het autonome zenuwstelsel bij borderline hypertensie}

Speelt het autonome zenuwstelsel een rol in de genese van essentiële hypertensie? Een vergelijkend onderzoek bij borderline hypertensieve en normotensieve controle personen van gelijke leeftijd.

\section{PROEFSCHRIFT}

ter verkrigging van de graad van doctor in de geneeskunde aan de Rijksuniversiteit Limburg te Maastricht, op gezag van de rector magnificus Prof. Dr.

W.H.F.W. Wijnen, hoogleraar in de faculteit der geneeskunde, volgens besluit van het college van dekanem in het openbaar te verdedigen in de aula van de universiteit op vrijdag 21 november 1980 des namiddags te vieruur.

\section{door}

Jan-Willem Henquet

geboren te Maastricht 
Promotor: Prof. Dr. K.H. Rahn

Referenten: Prof. Dr. R.A.P. Koene

Prof. Dr. H.A.J. Struyker Boudier 
Dit proefschrift werd bewerkt in de capaciteitsgroep farmacologie van de Rijksuniversiteit Limburg te Maastricht en op de Interne Afdeling van het Ziekenhuis St. -Annadal te Maastricht.

De uitgave van dit proefschrift is mogelijk gemaakt door medewerking van Smith Kline \& French B.V. 

Voor Godelieve,

Thomas,

Cecile en Lukas 


\section{Inhoudsopgave}

Hoofdstuk I.

blz.

Inleiding en doelstelling

- Literatuur

\section{Hoofdstuk II.}

'Hypertensie als menselijk fenomeen' onschuld of ernst?

- Korte geschiedenis van de bloeddrukmeting

- Definitie van het begrip hypertensie

- Incidentie van hypertensie

- Causale factoren in de genese van hypertensie

- Kwalificatie van hypertensie naar etiologie

- Incidentie van essentiële hypertensie versus secundaire hypertensie

- Kwalificatie van hypertensie naar ernst

- Hypertensie als risicofactor

- Verbetert behandeling de prognose?

- Borderline hypertensie en haar betekenis 25

- Literatuur

Hoofdstuk III.

\section{Hypertensie en het autonome zenuwstelsel}

- De bloeddrukregulatie met speciale aandacht voor de autonome zenuwreflexen

- De fysiologische anatomie van het efferente deel van het autonome zenuwstelsel, voor zover van belang voor de circulatie

- De neurotransmitters van het autonome zenuwstelsel en hun metabolisme

- Effecten van het autonome zenuwstelsel op de circulatie

- Langs welke wegen zou een stoornis van het autonome zenuwstelsel een hypertensie kunnen veroorzaken? 


\section{Hoofdstuk IV.}

Vergelljkende onderzoeken betreffende het autonome zenuwstelsel en de bloeddrukregulatie bij borderline hypertensieve en normotensieve controle personen.

- Inleiding

- Literatuur

1. Vergelijkend onderzoek naar de activiteit van het sympathische zenuwstelsel en het renine systeem bij borderline hypertensieve en normatensieve controle personen

- Inleiding en probleemstelling

- Proefpersonen en methoden

- Resultaten

- Discussie

- Literatuur

2. Vergelijkend onderzoek naar de verandering in hartfrequentie tijdens intraveneuze toediening van isoproterenol bij borderline hypertensieve en normotensieve controle personen

- Inleiding en probleemstelling

- Proefpersonen en methoden

- Resultaten

- Discussie

- Literatuur

3. Vergelijkend onderzoek naar de verandering in bloeddruk tijdens intraveneuze toediening van noradrenaline bif borderline hypertensieve en normotensieve controle personen

- Inleiding en probleemstelling

- Proefpersonen en methoden

- Resultaten

- Discussie

- Literatuur

4. Vergelljkend onderzoek naar de activitelt van het parasympathische zenuwstelsel bij borderline hypertensieve en normotensieve controle personen

- Inleiding en probleemstelling

- Proefpersonen en methoden

- Resultaten

- Discussie

- Literatuur

Samenvatting en slotbeschouwing

Summary and conclusive remarks 


\section{Hoofdstuk I. Inleiding en doelstelling}

Hel lijden aan hypertensie heeft belangrijke consequenties voor de persoon in kwestie. Hypertensie is immers én van de belangrijkste risicofactoren in de mortaliteit en morbiditeit van het hart-vaatlijden. Met de tegenwoordig beschikbare antihypertensiva is het mogelijk het allergrootste deel van de patiënten met hypertensie op een adequate wijze te behandelen. Aangetoond kon worden dat behandeling van hypertensie zinvol is doordat er door behandeling een verbetering van de prognose tot stand komt. Een beschrijving van de betekenis van hypertensie als menselijk fenomeen is de doelstelling van hoofdstuk II. Naar ons idee zal een dergelijke beschrijving de relevantie van een onderzoek naar de genese van essentiële hypertensie ondersteunen.

Hoewel er de laatste decennia op grote schaal onderzoek is gedaan naar de genese van essentiële hypertensie is het nog steeds niet duidelijk wat de oorzaak van dit ziektebeeld is. Het lijkt mogelijk dat inzicht in de pathofysiologie van essentiële hypertensie mogelijkheden zal bieden om te komen tot een rationele behandeling van deze aandoening.

Onderzoek naar de genese van essentiële hypertensie deed het inzicht in het complexe mechanisme van de bloeddrukregulatie groeien. Duidelijk werd dat het autonome zenuwstelsel op vele manieren invloed kan uitoefenen op deze bloeddrukregulatie. Tevens werd het duidelijk dat het autonome zenuwstelsel bij iedere bekende vorm van experimentele hypertensie opgewekt bij proefdieren, participeert bij het tot stand komen van de bloeddrukverhoging. Dit laatste zal in het hierna volgende, zonder te streven naar een volledig overzicht over de rol die het autonome zenuwstelsel speelt bij allerlei vormen van experimentele hypertensie, nader toegelicht worden

Bij dieren kan hypertensie op een aantal experimentele manieren opgewekt worden. Het is evident dat bij een aantal van deze manieren zoals. conditioneringsmethoden (Bykov, 1947; Myasnikov, 1961; Herd et al., 1969; Benson el al., 1970; Forsyth en Harris, 1970; Brady et al., 1972), stimulatie (Folkow en Rubinstein, 1966) en destructie van bepaalde delen van de hersenen (Doba en Reis, 1973, 1974) het autonome zenuwstelsel een rol speelt bij het ontstaan van de bloeddrukverhoging

Experimentele hypertensie kan tevens opgewekt worden door middel van een aantal andere technieken waarbij het autonome zenuwstelsel geen rol lijkt te spelen. Maar zoals hier beschreven zal worden heeft ook bij deze vormen van experimentele hypertensie het autonome zenuwstelsel grole betekenis. In dit verband noemen we de experimentele hypertensie veroorzaakt door ratten te behandelen mel desoxycorticosteron - acetaat (DOCA) en zout (Grollman et al., 1940; Knowlton et al., 1947), de hypertensie die ontstaat nadat er bij dieren een constrictie van de nierarterie is aangebracht 
(Goldblatt. 1947) en de genetisch bepaalde hypertensie die tot stand komt door ratten met bepaalde erfelijke eigenschappen met elkaar te kruisen. Voorbeelden van dergelijke genetisch hypertensieve ratten, die in de loop van hun leven hypertensie ontwikkelen, zijn de zogenoemde zout-gevoelige ratten (Dahl et al., 1962) en de spontaan hypertensieve ratten (Okamoto en Aaki, 1963).

Ratten met een DOCA hypertensie worden onder meer gekenmerkt door veranderingen van het autonome zenuwstelsel zoals een toegenomen perilere sympathische neuronale activiteit en een toegenomen aanmaak van catecholaminen in het bijniermerg (De Champlain, 1972; De Champlain en van Ameringen, 1973). DOCA hypertensie is te voorkomen door de dieren voor te behandelen met intra-ventrikulair toegediende 6-hydroxydopamine waardoor de catecholaminerge neuronen van de hersenstam ver woest worden (Finch et al., 1972). Is er evenwel eenmaal een DOCA hypertensie tot stand gekomen dan kan intra-ventrikulaire injectie van 6-hydroxydopamine de hypertensie niet meer ongedaan maken (Finch et al. 1972; Haeusler et al., 1972). Kennelijk spelen de neuronen van de hersenstam een rol in de ontwikkeling van DOCA hypertensie. Deze neuronen spelen ook een rol in de ontwikkeling van experimentele hypertensie die ontstaat nadat een constrictie van de nierarterie is aangebracht. Bij deze vorm van experimentele hypertensie kan intra-ventrikulaire toediening van 6-hydroxydopamine de hypertensie wel voorkomen maar niet ongedaan maken nadat een dergelike hypertensie eenmaal tot stand gekomen is (Chalmers, 1975).

Nog op een andere wijze participeert hel autonome zenuwstelsel in de ontwikkeling van hypertensie die ontstaat nadat er een constrictie van de nierarterie is aangebracht. De toegenomen renine afgifte aan de circulatie veroorzaakt een stijging van de angiotensine II produktie. Onder meer heeft angiotensine II een bloeddruk verhogende werking doordat angiotensine II de area postrema binnendringt (Joy en Lowe, 1970; Lewis et al., 1973). Het hierna optredende bloeddruk verhogende effect komt tot stand via catecholaminerge neuronen gelegen in de hersenstam, die aanleiding geven tot een toename van perifere sympathische zenuwactiviteit (Sweet en Brody., 1970; Gildenberg, 1971; Sweet en Brody, 1971: Fukyama, 1973). De effecten die ontstaan nadat angiotensine 11 de area postrema is binnengedrongen kunnen voorkomen worden door een catacholaminen-depletie van de hersenen op te roepen met behulp van reserpine (Sweet en Brody. 1971).

Ook in de ontwikkeling van genetische hypertensie speelt het autonome zenuwstelsel een rol, daar 6-hydroxydopamine intra-ventrikulair toegediend bij dieren jonger dan 10 weken de ontwikkeling van de bloeddrukverhoging voorkomt (Finch et al., 1972). Is de hypertensie bij spontaan hypertensieve dieren evenwel na 12 weken eenmaal tot stand gekomen dan kan 6-hydroxydopamine de bloeddrukverhoging niet meer ongedaan maken (Haeusler el al., 1972).

Uit deze reeks van waarnemingen blijkt dat bij alle vormen van experimentele hypertensie het autonome zenuwstelsel een rol in de genese van de bloeddrukverhoging speelt. Het lijkt waarschijnlijk dat ook in de genese van essentiele hypertensie bij de mens het autonome zenuwstelsel partici- 
peert in de ontwikkeling van die hypertensie. Het lijkt daarom interessant aspecten van hel autonome zenuwstelsel van mensen met een hypertensie te vergelijken met die van normotensieve personen. Daar een verhoogde bloeddruk, zeker als zij langer bestaat en ernstiger is, aanleiding geeft tot secundaire veranderingen, waardoor de kans om de primaire oorzaak van de hypertensie te ontdekken zal afnemen, kozen wij als proefpersonen mensen met een borderline hypertensie waarbij immers de bloeddrukverhoging nog niel erg uitgesproken is waardoor er waarschijnlijk nog geen belangrijke secundaire veranderingen tot stand zijn gekomen.

Hoe de bloeddrukregulatie tot stand komt en meer in het bijzonder op welke manieren het autonome zenuwstelsel een rol kan spelen in dit regulatie-mechanisme zal beschreven worden in hoofdstuk III. Hoe stoornissen van het autonome zenuwstelsel aanleiding zouden kunnen geven tot het ontstaan van een hypertensie zal aan het einde van datzelfde hoofdstuk beschreven worden.

In hoofdstuk IV zal het vergelijkende onderzoek betreffende hel autonome zenuwstelsel bij borderline hypertensieve en normotensieve controle personen beschreven worden. Dit hoofdstuk bestaat uit een aantal onderdelen waarin de afzonderlike aspecten van het autonome zenuwstelsel bestudeerd worden. De onderlinge relatie en de betekenis van de afzonderlijke onderzoeken zullen beschreven worden in de inleiding van hoofdstuk IV.

Aan het einde van dit proefschrift zal een samenvatting en slotbeschouwing gegeven worden. 


\section{Literatuur}

1. Benson, H. Herd, J.A., Morse, W.H., and Kelleker, R.T.

Behaviorally induced hypertension in the squirrel monkey.

Circ. Res. 26-27 (suppl. 1.) : 21, 1970

2. Brady, J.V., Anderson, D.E. and Harris, A.H.

Behavior and the cardiovascular system in experimental animals, in neural and psychologicial mechanisms in cardiovascular disease. edited by

A. Zanchetti, II Ponte, Milan, 1972. p. 47.

3. Bykov, K.M., :

The cerebral contex and the internal organs.

Moscow, Medgiz, 1947.

4. Chalmers, J.P.:

Brain amines and models of experimental hypertension.

Circ Res. 36: 469, 1975.

5. Dahl, L.K., Heine, M., Tassinari, L. :

Role of genetic factors in susceptibility to experimental hypertension due to chronic excess salt ingestion.

Nature (London) 194:480, 1962.

6. De Champlain, d.:

Hypertension and the sympathetic nervous system, in Perspectives in neuropharmacology (edited by S. Snyer).

Oxford, Oxford University Press, 1972.

7. De Champlain, J., van Ameringen, M.R.

Role of sympathetic fibres and of adrenal medulla in the maintenance of cardiovascular homeostasis in mormotensive and hypertensive rats, in Frontiers in catecholamine research (edited by $E$. Usdin and $S$. Snyer).

Oxford, Pergamon Press, 1973.

8. Doba, N., Reis, D.J.:

Acute fulminating neurogenic hypertension produced by brainstem lesions in the rat.

Circ. Res. $32: 584,1973$.

9. Doba, N., Reís, D.J.:

Role of central and peripheral adrenergic mechanisms in neurogenic hypertension produced by brainstem lesions in rats.

Circ. Res. $34: 293,1974$

10. Finch, L., Haeusler, G., Thoenen, H.:

Failure to induce experimental hypertension in rats after intraventricular injection of 6-hydroxydopamine.

Bi. J. Pharmacol. $44: 356,1972$.

11. Folkow, B., Rubinstein, E.H. :

Cardiovascular effects of acute and chronic stimulations of the hypothalamic defence area in the rat.

Acta Physiol. Scand. $68: 48,1966$ 
12. Forsyth, R.P., and Harris, R.E.

Circulatory changes during stressful stimuli in thesus monkeys.

Circ. Res. 26-27 (suppl. 1): 13, 1970.

13. Fukyama, K. :

Central modulation of baroreceptor reflex by angiotensin. Jap. Heart J. 14: 135, 1973.

14. Gildenberg, P.L.

Site of angiotensin vasopressor activity in the brainstem.

Fed. Proc. 30: 432, 1971.

15. Goldblatt, $\mathrm{H}$.

Renal origin of hypertension.

Physiol. Rev. $27: 120,1947$.

16. Grollman, A. Harrison, T.R., Willams, Jr. J.R.

The effect of various steroid derivates on the blood pressure of the rat.

J. Pharmacol. Exp. Ther. 69: 149, 1940.

17. Haeusler, G., Finch, L., Thoenen, H.:

Central adrenergic neurons and the initiation and development of experimental hypertension.

Experientia, 28: 1200, 1972.

18. Herd, J.A., Morse, W.H., Kelleker, R.T., and Jones, L.G. :

Arterial hypertension in the squirrel monkey during behavioral experiments.

Am. J. Physiol. 217: 24, 1969

19. Joy, M.D. Lowe, R.D. :

The site of cardiovascular action of angiotensin 11 in the brain.

Clin. Sci $39: 327,1970$.

20. Knowlton, A.J., Loeb, E.N., Stoerk, H.C., Seegal, B.C :

Desoxycorticosteron acetate. The potentation of its activity by sodium chloride.

J. Exp. Med. $85: 187,1947$.

21. Lewis, P.J., Reid, J.L., Chalmers, J.P., Dollery, C.T. :

Importance of central catecholaminergic neurons in the development of renal hypertension.

Clin. Sci. 45: 115, 1973

22. Myasnikov, A.L. :

The significance of disturbances of higher nervous activity in the pathogenesis of hypertensive disease, in The pathogenesis of essential hypertension, edited by J.H. Cort, V. Fencl, Z. Hejl, and J. Jirka. State medical Publishing house, Prague, 1961, p. 153.

23. Okamoto, $\mathrm{K}$, Aoki, $\mathrm{K}$.:

Development of a strain of spontaneously hypertensive rats. Jap. Circ. J. $27: 282,1963$.

24. Sweet, C.S., Brody, M.J.:

Central inhibition of reflex vasodilatation by angiotensin and reduced renal pressure.

Am. J. Physiol 219:1751, 1970.

25. Sweet, C.S., Brody, M.J.:

Arterial hypertension elecited by prolonged intravertebral infusion of angiotensin in the conscious dog.

Fed. Proc. $30: 432,1971$ 


\section{Hoofdstuk II. 'Hypertensie als menselijk fenomeen' onschuld of ernst?}

\section{- Korte geschiedenis van de bloeddrukmeting}

In 1827 beschreef Richard Bright (Bright, 1827) het samengaan van linkerkamemypertrofie met schrompelnieren. De etiologie van dit ziektebeeld was niet duidelijk. De sphygmomanometrische bloeddrukmeting was in die jaren nog niet bekend. In de loop van de $19 e$ eeuw ontwikkelden fysiologen methoden om bloedig en onbloedig de bloeddruk bij dieren te bepalen, maar slechts zeer sporadisch werd er een poging gedaan bij de mens de arteriële druk te meten. De apparatuur was nog weinig geschikt en onnauwkeurig zodat er nergens routinematig bloeddrukmetingen werden gedaan (Major, 1930). Ook de door Slegfried Karl Ritter von Basch (1881) in de jaren rond 1880 ontwikkelde bloeddrukmeter vond geen ingang in de kliniek.

Een Engeise arts, Frederick Mohamed (1849-1884) was waarschijnlijk de eerste die bloeddrukmetingen als routine-onderzoek in de kliniek trachtte te introduceren. Zijn eerste resultaten van onderzoek publiceerde hij in 1874 onder de titel 'The Etiology of Bright's Disease and the Prealbuminuric Stage' (Mohamed, 1874). Riva-Roccl slaagde er in 1906 in een apparaat te ontwikkelen dat zo goed bruikbaar was dat het spoedig overal in de klinieken werd gebruikt. Voor de gezondheidszorg werd de bloeddrukmeter spoedig een onmisbaar instrument.

\section{- Definitie van het begrip hypertensie}

Naarmate de klinische betekenis van 'verhoogde bloeddruk' groter werd en er alom onderzoek werd gedaan op het gebled van de hypertensie. ontstond behoefte aan een werkzame definitie van het begrip 'hypertensie'.

In 1962 adviseerde een commissie van de World Health Organization te spreken over hypertensie als de systolische bloeddruk hoger is dan $160 \mathrm{~mm}$ $\mathrm{Hg}$ en/of de diastolische bloeddruk hoger is dan $95 \mathrm{~mm} \mathrm{Hg}$ (WHO, 1958). Bloeddrukwaarden kleiner dan of gelijk aan $140 / 90 \mathrm{~mm} \mathrm{Hg}$ worden als normale waarden gezien.

Bloeddrukken met waarden gelegen tussen beide grenzen, dus lager dan of gelijk aan $160 / 95 \mathrm{~mm} \mathrm{Hg}$ maar hoger dan $140 / 90 \mathrm{~mm} \mathrm{Hg}$, worden vaak aangeduid als 'borderline hypertensie: Aan dit begrip zal aan het einde van dit hoofdstuk een aparte paragraaf gewijd worden. 


\section{- Incidentie van hypertensie}

Hypertensie is een wereldwijd gezondheidszorgprobleem. Door de United States Health Service werd tussen 1960 en 1962 een bevolkingsonderzoek in de Verenigde Staten van Amerika verricht waarbij geschat werd dat 17 miljoen mensen aan hypertensie leden (Gordon en Devine, 1966).

Wilhelmsen et al. (1973) onderzochten 2180 willekeurig gekozen mannen uit de stad Göteborg in de leeftijd van 43 tot 46 jaar en vonden dat $55 \%$ van die mannen een systolische bloeddruk had van $160 \mathrm{~mm} \mathrm{Hg}$ of hoger en/of een diastolische bloeddruk van $95 \mathrm{~mm} \mathrm{Hg}$ of hoger. In datzelfde jaar publiceerden Prineas et al. (1973) de resultaten van een studie die gedaan werd in Albury, Australië. Zij onderzochten mannen en vrouwen van 50 tot 59 jaar en vonden dat $12,7 \%$ van deze personen een diastolische bloeddruk had van $110 \mathrm{~mm} \mathrm{Hg}$ of hoger.

Van de populatie tussen 30 en 62 jaar, die participeerde in het Framingham onderzoek, bleken $18 \%$ van de mannen en $16 \%$ van de vrouwen hypertensief te zijn op het moment dat zij werden opgenomen in de studie. De deelnemers werden als hypertensief beschouwd als er bij twee metingen bloeddrukken werden gevonden van systolisch hoger dan of gelijk aan $160 \mathrm{~mm} \mathrm{Hg}$ en/of diastolisch hoger dan of gelijk aan $95 \mathrm{~mm} \mathrm{Hg}$. Deze percentages waren zelfs respectievelijk 40 en 48 indien borderline waarden (140 tot $159 \mathrm{~mm} \mathrm{Hg}$ systolisch en 90 tot $95 \mathrm{~mm} \mathrm{Hg}$ diastolisch) werden meegerekend (Frohlich et al., 1971).

Het allergrootste deel van de mensen met een hypertensie lijdt aan een essentiële hypertensie. Dit is een vorm van hypertensie waarvan bil de huidige stand van zaken de oorzaak niet bekend is. Dit in tegenstelling to de situatie waar sprake is van een secundaire hypertensie, een vorm van hypertensie waar het met de momenteel ter beschikking staande diagnostische methoden wel mogelijk is een oorzaak van de hypertensie aan te geven.

Indien er verder in dit proefschrift gesproken wordt over hypertensie, wordt steeds de essentiële vorm bedoeld, tenzij uitdrukkelijk anders vermeld wordt.

\section{- Causale factoren in de genese van hypertensie}

Hoewel, zoals hierboven reeds gesteld, de oorzaak van hypertensie niet bekend is, kan men zich toch afvragen onder invloed van welke factoren de ene mens een hypertensie ontwikkelt en de ander dit niet doet. Een opvallende bevinding is bijv. dat hypertensie in bepaalde families meer voorkomt dan in andere. Mede onder invloed van soortgelijke waarnemingen ontstond de discussie in hoeverre hypertensie een erfelijke aandoening is. Algemeen wordt nu aangenomen dat de hoogte van de bloeddruk van een bepaald individu word bepaald door een groot aantal factoren, waarbij onder meer erfelike eigenschappen een rol spelen. Hoe groot die rol exact is, is nog niet duidelijk. Het lijkt zeer wel mogelijk dat bepaalde exogene omstandigheden mede bepalen of aangeboren eigenschappen manifest worden of niet. Zo zullen bepaalde vormen van genetisch bepaalde hyper- 
lensie alleen dan aanleiding geven tot een kinisch manifeste hypertensie indien de dragers van die eigenschappen blool gesteld worden aan bepaaide simuli. Een fraai voorbeeld van een dergelike situatie zijn de ratten die Dahl et al. (1962) bestudeerden. Deze dieren waren te verdelen in 'salt-sensitive' en 'insensitive'; de eerste groep ratten ontwikkelde een hypertensie naarmate zij meer zout consumeerden, lerwijl dieren in de tweede groep ondanks een grotere zoutconsumptie normotensief bleven Een vergelijkbare situalie werd beschreven in bepaalde tamilies waar dochters van hypertensieve ouders alleen dan een hypertensie ontwikkelden indien ze zwanger werden (Brown en Dodds, 1939; Brown en Shemack, 1956).

Rasgebonden invloeden lijken een rol te spelen in het voorkomen van hypertensie. Zo is bijv. de incidentie in sommige groepen van de plattelandsbevolking in Afrka hoog. Dat ook hier bijkomende factoren een niet onbelangrijke rol spelen, lijkt waarschijnlijk, daar de incidentie verder toeneemt bij de bewoners die verhuisden van het platteland naar de grote steden (Shaper, 1969).

Dat genetische invloeden een zeer sterke invloed kunnen hebben op het krijgen van een hypertensie werd gedemonstreerd in de beschrijving van de zlektegeschiedenis van identieke tweelingen, die, hoewel in sommige gevallen levend op andere delen van de wereld, op ongeveer dezelfde leeftijd een hypertensie ontwikkelden (Platt, 1963).

Epidemiologische studies demonstreerden verscheidene malen het samengaan van overgewicht en hypertensie, hoewel de causale relatie niet duidelik is. Heyden et al. (1969) bestudeerden gedurende 7 jaar adolescenten en waren in staat een duidelijke correlatie aan te geven tussen lichaamsgewicht en bloeddruk. Kannel et al. (1967) toonden met materiaal van de Framingham-studie aan dat personen met een overgewicht van $20 \%$ of meer, 10 maal zo vaak hypertensie ontwikkelen als mensen met een normaal lichaamsgewicht.

Of voedingsgewoonten met betrekking tot de dagelijkse zoutopname een rol spelen in de genese van hypertensie is nog steeds omstreden. Hypertensie zou vrijwel niet voorkomen bil bepaalde bevolkingsgroepen op Nieuw-Guinea en de Salomonseilanden waar de bevolking slechts zeer weinig zout gebruikt (Prior en Evans, 1969). Aldus lijkt het suggestief te veronderstellen dat een lage zoutbehoefte op de éen of andere wijze zou samengaan met een normale bloeddruk. Evenwel, bij een smaakexperiment waarbil de proefpersonen de mogelijkheid werd geboden te kiezen uit $3 \mathrm{kommen}$ met soep, die in opklimmende mate gezouten was, werd er een omgekeerde correlatie gevonden tussen de hoogte van de bloeddruk en de voorkeur voor zout (Paul en Ostfelt, 1965). In de Framingham-studie (Dawber et al. 1967) kon er geen correlatie gevonden worden tussen de hoogte van de bloeddruk en de dagelijkse zoutconsumptie. In een editorial van de Lancet werd hel zoutprobleem als volgt samengevat: "To put it al its simplest, we still do not know what role abnormalities of sodium intake or metabolism play in the genesis of essential hypertension' (Lancet, 1975).

Mogelijk zal epldemiologisch onderzoek er in de toekomst toe bijdragen dat een beter inzicht wordt verkregen in de factoren die een rol spelen bij de genese van hypertensie. 


\section{- Kwalificatie van hypertensie naar etiologie}

In het in deze paragraaf weergegeven overzicht worden de verschillende vormen van hypertensie vermeld (Julius, 1977). Later in dit hoofdstuk wordt ingegaan op de incidentie van essentiële hypertensie versus secundaire hypertensie.

A: Essentiële hypertensie. B $t / m H$ : vormen van secundaire hypertensie.

A. Essentiële hypertensie

B. Renaal

1. parenchymateus - acute glomerulonefritis

- glomerulonefritis; pyelonefritis; hereditaire nefritis; bestralingsnefritis; lupus erythematodes nefritis

- cyste nieren

- hydronefrose

- renine producerende tumor

- diabetische nefropathie (Kimmelstiel-Wilson)

2. renovasculair - fibromusculaire stenose

- atherosclerotische stenose

- nierinfarct

- polyarteritis

3. trauma

- perirenaal haematoom

- nierarterie thrombose

- aneurysma van nierarterie

C. Endocrien

Bijnier

- pheochromocytoom

- primair aldosteronisme; adenoom; hyperplasie; met glucocorticoïden te onderdrukken hyperaldosteronisme

- congenitale bijnierhyperplasie; 11-hydroxylase deficientie: 17 -hydroxylase deficiëntie

- Cushing

D. Neurogeen

- respiratoire acidose

- hersentumor

- encephalitis

- bulbaire poliomyelitis

- familiaire dysautonomie

- acute porphyrie

- extra-adrenale chromatophine tumoren

E. Mechanische stoornissen

- coarcatio-aortae

- atherosclerotische systolische hypertensie 
1. - vergiftigingen: Iood; thallium

2. - medicatie: sympathomimetica; MAO-remmers in combinatie met ephedrine of tyramine (tyramine-rijk voedsel, kaas, rode wijn); orale anticonceptiva; glucocorticoiden in hoge dosering

3. - overmatig dropgebruik

4. - jatrogeen; overhydratie bij beperkte nierfunctie.

G. Zwangerschapstoxicose

H. Andere situaties - polycythaemie

- verbrandingen

- carcinoid syndroom

In het kader van dit proefschrift, waarin een onderzoek naar de genese van hypertensie beschreven wordt, zal niet verder ingegaan worden op de vormen van secundaire hypertensie. Voor de volledigheid zij verwezen naar handboeken en reviews aangaande de genese van secundaire hypertensie.

\section{- Incidentie van essentiële versus secundaire hypertensie}

Tot voor kort werd aangenomen dat 80 tot $90 \%$ van de patiènten met een hypertensie zouden lijden aan een essentiële hypertensie. Op grond van recente onderzoeken moet evenwel aangenomen worden dat dit percentage nog groter is. Bij een onderzoek in Zweden (Berglund et al., 1976), waarbij hypertensieve mannen van middelbare leeftijd waren betrokken, werd ad random iedere derde patiënt uitvoerig onderzocht, waarbij getracht werd de oorzaak van de bestaande hypertensie op te sporen. Slechts bij $5,8 \%$ van de mannen was er sprake van een secundaire hypertensie, hetgeen betekent dat er in $94,2 \%$ sprake was van een essentiële hypertensie. Deze bevindingen stemmen overeen met die van een Zwitsers onderzoek (Greminger et al., 1977), waarbij alle nieuwe patiënten, die in het jaar 1975 voor de eerste maal de hypertensiepolikliniek van het universiteitsziekenhuis van Zürich bezochten, uitvoerig onderzocht werden. Slechts bij $7,1 \%$ van deze hypertensieve populatie was het mogelijk de oorzaak van hun hypertensie aan te geven, hetgeen betekent dat $92,9 \%$ van de patiënten een essentiële hypertensie hadden.

\section{- Kwalificatie van hypertensie naar ernst}

De kwalificatie van hypertensie naar ernst is eigenlijk een klinische classificatie; naast de hoogte van de bloeddruk spelen klinische parameters een rol. Naargelang de hypertensie langer bestaat en/of gekenmerkt wordt door hogere bloeddrukwaarden zullen er bij de patiënt tekenen 
gevonden worden van cardiovasculaire hypertrofie en/of orgaanbeschadiging. Voor de kwalificatie van hypertensie naar ernst zijn de belangrijkste parameters: de fundus oculi, het ECG, de bevindingen bij het urine-onderzoek, de nierfunctie, en de eventueel aanwezige encephalopathie. De oogfundus kan normaal zijn of afwijkingen tonen die geclassificeerd worden volgens Keith, Wagener en Barger en van toenemende ernst in een schaal opklimmend van $1 \mathrm{t} / \mathrm{m} 4$. Het ECG kan het beeld laten zien van linkerkamerhypertrofie $(\mathrm{LVH})$, in de urine kan eiwit gevonden worden terwijl de nierfunctie normaal of verminderd kan zijn. In tabel 1 wordt de klinische classificatie van hypertensie weergegeven (Julius, 1977). De 3 principes van deze classificatie zijn:

1. Zelfs in het geval dat er sprake is van hoge bloeddrukwaarden behoeven er niet noodzakelijk laboratoriumafwijkingen aanwezig te zijn. In dergelijke situaties is de ernst van de hypertensie direct gerelateerd aan de hoogte van de bloeddruk.

2. Indien er bij een bepaalde hoogte van de bloeddruk tevens laboratoriumafwijkingen aantoonbaar zijn, dan is de hypertensie ernstiger en valt in een hogere categorie.

3. De aanwezigheid van fundusafwijkingen betekent dat er sprake is van vaatbeschadiging. Deze afwijkingen zijn dan bepalend voor de ernst van de hypertensie. Bij retinopathie graad 3 en 4 is er zeker sprake van ernstige hypertensie, ongeacht de hoogte van de op dat moment gemeten bloeddruk.

Indien men borderline hypertensie ook bij deze classificatie wil betrekken, hetgeen vanuit klinisch oogpunt wel zinvol is, kunnen we met behulp van deze indeling 5 categorieën onderscheiden, t.w. : borderline hypertensie, milde hypertensie, matige hypertensie, ernstige hypertensie, en maligne hypertensie. 
Tabel 1

Klinische classificatie van hypertensie

\begin{tabular}{|c|c|c|c|c|c|}
\hline Categorie & Bloeddruk & Fundus & $E C G$ & Urine & Nierrunctie \\
\hline $\begin{array}{l}\text { borderline } \\
\text { hypertensie }\end{array}$ & borderline & normaal & normaal & normaal & normaal \\
\hline \multirow[t]{2}{*}{$\begin{array}{l}\text { milde } \\
\text { hypertensie }\end{array}$} & borderline & $\begin{array}{l}\text { graad } 1 \\
\text { of } 2+\end{array}$ & $\mathrm{LVH}+$ & normaal & normaal \\
\hline & $\begin{array}{l}161 / 101 \\
180 / 120\end{array}$ & $\begin{array}{l}\text { normaal of } \\
\text { graad } 1-2\end{array}$ & normaal & normaal & normaal \\
\hline \multirow[t]{2}{*}{$\begin{array}{l}\text { matige } \\
\text { hypertensie }\end{array}$} & $\begin{array}{l}161 / 101 \\
180 / 120\end{array}$ & $\begin{array}{l}\text { normaal of } \\
\text { graad } 1-2\end{array}$ & $\mathrm{LVH}+$ & eiwit & $\begin{array}{l}\text { verminderd } \\
+\end{array}$ \\
\hline & $\begin{array}{l}181 / 121 \\
190 / 130\end{array}$ & $\begin{array}{l}\text { normaal of } \\
\text { graad } 1-2\end{array}$ & $\neq$ & + & $\neq$ \\
\hline \multirow[t]{2}{*}{$\begin{array}{l}\text { ernstige } \\
\text { hypertensie }\end{array}$} & hypertensie & $\begin{array}{l}\text { bloedingen } \\
\text { en exudaten } \\
\text { graad } 3\end{array}$ & \multirow{2}{*}{ \pm} & \multirow{2}{*}{+} & \multirow{2}{*}{7} \\
\hline & $>191 / 131$ & graad 2 & & & \\
\hline $\begin{array}{l}\text { maligne } \\
\text { hypertensie }\end{array}$ & hypertensie & $\begin{array}{l}\text { papiloedeem } \\
\text { (graad } 4 \text { ) }\end{array}$ & 乎 & f & + \\
\hline
\end{tabular}

+ Indien een van deze tekenen aanwezig is.

* Deze laboratoriumgegevens hoeven niet afwikkend te zijn.

In dit schema van de klinische classificatie van hypertensie is te zien hoe bij een bepaalde patiënt gevonden veranderingen in de fundus oculi, het ECG, de urine of de nierfunctie aanteiding geven tot kwalificatie van zijn hypertensie in een hogere categorie. Zo zal bij een patiënt met bloeddrukwaarden gelegen tussen $161 / 101$ en $180 / 120 \mathrm{~mm} \mathrm{Hg}$ zonder LVH, zonder proteinurie en zonder een verminderde nierfunctie sprake zijn van een milde hypertensie. Een patient met dezelfde bloeddrukwaarden maar mel of tekenen van LVH of proteinurie of verminderde nierfunctie, zal een hypertensie hebben die geclassificeerd wordt als zijnde: matig ernstig. Een hypertensieve patiênt, die tengevolge van zijn hypertensie papiloedeem ontwikkeld heeft, heeft volgens deze classificatie steeds een maligne hypertensie ongeacht de bloeddrukwaarden die op dat moment gemeten worden.

Op ieder niveau van ernst kan de hypertensie al dan niet gecompliceerd zijn. Er is sprake van een gecompliceerde hypertensie als er tengevolge van de te hoge bloeddruk complicaties zijn ontstaan, zoals: angina pectoris, 
decompensatio cordis, ritmestoornissen, myocardinfarct, cerebrovasculaire accidenten, en aneurysmata.

\section{- Hypertensie als risicofactor}

In 1939 wezen Keith, Wagener en Barker (Keith et al., 1939) erop hoe de prognose van een hypertensieve patiènt slechter wordt naarmate er bij zijn hypertensie ernstiger funduscopische afwijkingen bestaan, geclassificeerd volgens de schaal voorgesteld door genoemde auteurs.

Uit een later onderzoek (Sarre en Lindner, 1948) bleek dat de overlevingskansen van niet behandelde hypertensieve patiënten omgekeerd evenredig waren met de hoogte van hun bloeddruk. De grote levensverzekeringsmaatschappijen (Metropolitan Life Insurance Company, 1961) beschouwden reeds spoedig hypertensie als één van de belangrijkste prognostische parameters bij het vaststellen van hun premies.

In een 20 jaar durende vervolgstudie (Breslin et al., 1966) werd aangetoond dat de mortaliteit van patiënten met fundusafwijkingen volgens K.W.B.-graad 1 en 2 weliswaar lager is dan van patienten met meer uitgesproken fundusafwijkingen, maar dat deze mortaliteit na 5 - 15 jaar duidelijk groter was dan bij mensen zonder hypertensie. Opgemerkt dient nog te worden dat deze oversterfte weliswaar procentueel niet zo groot was, evenwel gezien het zeer grote aantal patiènten lijdend aan hypertensie gaat het absoluut gezien om een groot aantal patiënten.

Sedert de jaren zestig volgde er een stroom van publicaties waaruit geconcludeerd moest worden dat hypertensie een belangrijke rol speelt in de genese van cardiovasculaire morbiditeit en mortaliteit (Sokolow en Perloff, 1961 ; Lew, 1967 ; Mathisen et al., 1969 ; Kannel en Dawber, 1974 ; Paul, 1971, 1974). Kannel et al. $(1970,1971,1972)$ bestudeerden veel van het materiaal dat de Framingham-studie opleverde. De Framingham-studie werd gestart in 1949 met als doel een onderzoek te doen naar de epidemiologie van cardiovasculair lijden, waarbij een steekproef bij 5302 mannen en vrouwen tussen de 30 en 62 jaar van jaar tot jaar gevolgd werd (Dawber et al., 1963; Gordon en Kannel, 1971; Shurtleff, 1974). Uit deze studies blijkt op zeer indrukwekkende wijze welk een belangrijke rol hypertensie speelt in de genese van cardiovasculaire morbiditeit en mor taliteit. Vergeleken met normatensieven ontwikkelen patiënten met hypertensie veel frequenter cardiovasculaire ziektebeelden. In de leeftijdsgroep van 45 tot 74 jaar werd er in de hypertensieve populatie tweemaal zoveel ernstig perifeer vaatlijden gezien als in de normotensieve groep. In de hypertensieve groep ontstond driemaal zoveel coronair vaatlijden, vijfmaal zoveel decompensatio cordis en achtmaal zoveel cerebrovasculair lijden als in de normotensieve groep.

Ook uit het bevolkingsonderzoek dat Holme en Waaler (1976) uitvoerden in Noorwegen werd duidelijk dat er een uitgesproken toename van de sterfteciffers bij mensen met hypertensie bestaat. In dit onderzoek werd onder meer waarschijnlijk gemaakt dat de kans op coronair lijden bij mannen van middelbare leeftijd exponentieel stijgt met de hoogte van de bloeddruk.

Op welke indrukwekkende wijze hypertensie de levensverwachting kan 
beinvloeden, wordt overtuigend gedemonstreerd door patienten met ernstige vormen van hypertensie en met name door patienten met maligne hypertensie voordat er effectieve antihypertensiva beschikbaar waren: zo werd er in de studie van Schottstedi en Sokolow (1953) aangetoond dat de gemiddelde overlevingstijd van 86 patiënten met maligne hypertensie slechts 8,4 maanden was; slechts 6 patienten leefden langer dan 2 jaar. Vijf patienten stierven binnen 3 maanden nadat de maligne hypertensie was ontstaan, de meesten onder het beeld van een nierinsufficiëntie met uremie.

\section{- Verbetert behandeling de prognose?}

Farmacologische behandeling van hypertensie werd mogelijk door het ter beschikking komen van antihypertensiva. In het kader van dit proefschrift zien we af van een bespreking van de behandeling van hypertensie. Voor de volledigheid wordl aangaande dit onderwerp verwezen naar handboeken en reviews.

De vraag dringt zich op of behandeling van hypertensie de kans op toegenomen morbiditeit en mortaliteit doet afnemen. Pas als deze vraag positief beantwoord kan worden, is antihypertensieve behandeling zinvol.

Voor de meest ernstige vorm van hypertensie. de maligne hypertensie, werd door Harrington et a: (1959) aangetoond dat, ondanks de destijds nog gebrekkige antihypertensieve middelen, een duidelijke verbetering van de levenskansen ontstond als deze patiënten behandeld werden. Van de niet behandelde patiënten was er na 3 jaar geen enkele meer in leven, terwijl in de behandelde groep na 3 jaar nog $30 \%$ in leven was

Dat de kans op ernstige hypertensieve complicaties, zoals papiloedeem, kleiner wordt door behandeling van hypertensie, werd aangetoond door Breckenridge et al. (1959). Zij bestudeerden de gegevens van de hypertensiekliniek van het Hammersmith Hospital en zagen dat er een afname was van het voorkomen van graad 4 funduspathologie volgens K.W.B. naarmate een groter deel van de hypertensieve populatie werd behandeld met anthypertensiva.

Door de Veterans Administration Cooperative Study Group on Antihypertensive Agents (1967, 1970) werd aangetoond dat antihypertensieve behandeling van patiënten met een niet-maligne hypertensie winst voor de patiênten opleverde. De studiegroep publiceerde onder meer twee studies. De eerste studie werd gepubliceerd in 1967. Bestudeerd werden mannen met een diastolische bloeddruk tussen 115 en $129 \mathrm{~mm} \mathrm{Hg}$. De patientenpopulatie werd verdeeld in een behandelde en een niet behandelde groep. Daar evenwel al zeer snel bleek dat de prognose van de onbehandelde mannen veel slechter was dan die van de behandelde mannen, moest de studie na 3 jaar afgebroken worden. In 1970 rapporteerde dezelfide studiegroep haar resultaten van een groep patiënten met een diastolische bloeddruk tussen 90 en $114 \mathrm{~mm} \mathrm{Hg}$. Ook hier was weer sprake van een behandelde en een niet behandelde groep. Na 5 jaar follow-up bleek de betere prognose van de behandelde groep overduidelijk. Overtuigend kan worden aangetoond dat door behandeling van hypertensie de kans op het 
ontstaan van hypertensieve complicaties, zoals nierinsufficiëntie, visusstoornissen en decompensatio cordis kleiner wordt. Ook werd aangetoond dat behandeling de kans op cerebrale complicaties doet afnemen (Carter, 1970 ; Beevers et al., 1973).

Recentelijk werd door de Hypertension Detection and Follow-up Program Cooperative Group van het National Institute of Health U.S.A. (1979) aangetoond dat systematische effectieve behandeling van hypertensie een belangrijke reductie in mortaliteit veroorzaakt bij mensen met hypertensie.

Tot op heden is er evenwel nog nimmer een studie gepubliceerd waarin overtuigend werd aangetoond dat de kans op coronair lijden afneemt door antihypertensieve therapie. Coronairsclerose is naar alle waarschijnlijkheid sterk multiconditioneel bepaald en lijkt daarbij zeer vroeg in het leven te beginnen. Wil men aantonen dat antihypertensieve therapie een gunstig effect heeft op de kans een coronair lijden te krijgen dan lijkt het waarschijnlijk dat een dergelijk effect alleen dan aantoonbaar is, indien men vroeg met de antihypertensieve behandeling start. Berglund et al. (1977, 1978) publiceerden twee studies, waarin bestudeerd werd wat het effect is van antihypertensieve therapie op de prevalentie van het coronair lijden. In de met antihypertensiva behandelde populatie was er een vermindering te zien van het coronair lijden hoewel deze afname statistisch niet significant was. Het lijkt waarschijnlijk dat het gunstige effect van behandeling pas goed duidelijk wordt als op grote schaal ook lichtere vormen van hypertensie in een vroeg stadium worden behandeld.

\section{- Borderline hypertensie en haar betekenis}

Aan het slot van dit hoofdstuk zal er een afzonderlijke paragraaf besteed worden aan het begrip borderline hypertensie, daar het verderop beschreven onderzoek werd verricht met proefpersonen met een borderline hypertensie. Waarom juist personen met een borderline hypertensie gevraagd werden in het onderzoek te participeren zal elders besproken worden.

Borderline hypertensie kan het beste omschreven worden als een situatie waarbij een bepaalde persoon bloeddrukwaarden heeft die te hoog zijn om als geheel normaal beschouwd te worden, terwijl ze aan de andere kant niet zo hoog zijn dat ze als hypertensief aangemerkt kunnen worden. Overeenkomstig het voorstel van de W.H.O. worden bloeddrukwaarden hoger dan $160 / 95 \mathrm{~mm} \mathrm{Hg}$ gezien als hypertensteve bloeddrukwaarden (W.H.O., 1958). Bloeddrukwaarden lager dan $140 / 90 \mathrm{~mm} \mathrm{Hg}$ worden gezien als normale bloeddrukken. In een later rapport van de W.H.O. (1962) werd benadrukt dat bloeddrukwaarden gelegen tussen $160 / 95$ en $140 / 90 \mathrm{~mm} \mathrm{Hg}$ zeker niet als normale bloeddrukken gezien mochten worden; speciaal indien deze waarden gevonden worden bij jonge mensen dient er extra aandacht aan gegeven te worden. In de praktijk gebruikt men vaak het woord borderline hypertensie om deze situatie aan te duiden.

Borderline hypertensie is een frequent voorkomende stoornis in de bloeddrukregulatie. Uit twee grote bevolkingsonderzoeken gedaan in de Verenigde Staten van Amerika (PHS PUBL, 1966; Alameda County Blood 
Pressure Study, 1968) blikt dat ongeveer $10 \%$ van de jongere mannelijke bevolking tussen 25 en 40 jaar een borderline hypertensie heeft. Met het klimmen van de leeftijd stijgt dit percentage sterk. Bij jonge vrouwen wordt veel minder vaak een borderline hypertensie gevonden (Julius en Schork, 1971). Evenwel ongeveer vanaf het 45 ste tot 50ste levensjaar is de prevalentie van borderline hypertensie bij vrouwen en mannen van gelijke grootte en wel ongeveer 20 tot $25 \%$ van de populatie in die leettijdsgroepen (PHS PUBL, 1966: Alameda County Blood Pressure Study, 1968).

Ook in andere landen dan de Verenigde Staten is de prevalentie van borderline hypertensie groot. Bij een onderzoek, waarbij mensen van middelbare leettijd en ouder waren betrokken, werden de volgende cijters gevonden: in Duitsland resp. 29 en $28 \%$ (Moeller en Heyder, 1969; Brenneke et al., 1975), Noorwegen 10 tot $13 \%$ (Bøe et al., 1957), Rusland $12 \%$ (Volkov, 1972). In 1973 maakte een groep experts van het National High Blood Pressure Program (1973) de schatting dat er in Amerika ongeveer 16 miljoen mensen borderline hypertensief zouden zijn.

Vergeleken met de normotensieven heeft iemand met een borderline hypertensie een toegenomen kans later in zijh leven hypertensie te krijgen. Alle thans beschikbare studies waarin dit aspect bestudeerd werd, laten zien dat de kans die een borderline hypertensieve patient heeft om later hypertensief te worden tenminste tweemaal zo groot is als bij normotensieve mensen (Evans, 1957; Mathewson, 1957; Stamler et al., 1958; Kooperstein et al., 1962; Jutius et al, 1964; Paffenbarger et al., 1968). In de retrospectieve studie van Julius et al. (1964) werd zelts gevonden dat $26 \%$ van de borderline hypertensieve patiënten, hypertensief wordt. In deze laatste studie werd gevonden dat van de oorspronkelijk normotensieve mensen $12 \%$ hypertensief was geworden na 10 tot 15 jaar.

De mortaliteit van patienten met borderline hypertensie is groter dan de mortaliteit van normotensieven (Mackenzle en Shepherd, 1937 ; Levy et al., 1944; Thomson, 1950; Storm-Mathisen et al., 1965; Lew, 1967). De grootte van deze toegenomen mortaliteit wisselt in de verschillende studies maar is steeds groter dan 100\%, in twee studies bijna $200 \%$ (Thomson, 1950; Lew, 1967) en in één studie zelfs $300 \%$ (Levy et al., 1944).

De morbiditeit van het coronair lijden is bij patienten met borderline hypertensle groter dan bij normotensieve mensen. In een aantal studies (Thomson, 1950; Stamler et al., 1958; Kooperstein et al., 1962 ; Kannel et al., 1969; Julius en Schork, 1971), waarbil patiënten met een borderline hypertensie gedurende een langere tijd vervolgd werden, kon deze toegenomen morbiditeit overtuigend aangetoond worden.

Meer dan slechts een lichte verhoging van de bloeddruk lijkt het begrip borderline hypertensie een complexe situatie aan te duiden onder meer gekenmerkt door een toegenomen mortaliteit en morbiditeit. Daarbij komt nog dat in een groot aantal studies afwijkingen in de normale fysiologische verhoudingen van de circulatie werden gevonden. Ongeveer $30 \%$ van de borderline hypertensieve patienten heeft in rust een groter hartminuutvolume dan normotensieven; daarbij werd aangetoond dat borderline hypertensieve mensen in rust cen hogere hartfrequentie hebben dan normoten- 
sieven. Neurogene invloeden lijken een rol te spelen in deze toename van hel hartminuutvolume. Zo werd door Julius et al. (1971a) aangetoond dat het hartminuutvolume van borderline hypertensieven en normotensieven in rust pas van gelijke grootte wordt nadat het effect van het autonome zenuwstelsel op het hart volledig geblokkeerd is middels propranolol en atropine. Tevens werd aangetoond dat de toename van het slagvolume van het hart, opgewekt door een doen toenemen van de veneuze vulling, bij patiënten met een borderline hypertensie meer uitgesproken is dan bij normotensieven. Dit effect lijkt te berusten op een toestand van toegenomen inotropie van het hart onder invloed van de sympathicus (Ellis en Julius, 1973). Door de groep van Julius werd tevens aangetoond dat de hogere hartfrequentie van patiënten met een borderline hypertensie niet berust op een frequenter stimulerende gangmaker van het hart, maar dat deze snellere hartactie ontstaat onder invloed van neurogene invloeden (Julius et al., 1971a).

De normale fysiologische relatie tussen het hartminuutvolume en de perifere weerstand is bij mensen met een borderline hypertensie verstoord. De perifere weerstand is bij mensen met een borderline hypertensie of toegenomen, vergeleken met die van normotensieven, of gelijk aan die van normotensieven, maar is dan te hoog ten opzichte van het in deze situatie gemeten hartminuutvolume (Julius et al., $1971 \mathrm{~b}$ ). Het mechanisme waardoor deze abnormale perifere weerstand tot stand komt, is niet volledig opgeheiderd, mogelijk speelt een neurogene dysregulatie een rol. Voor een bepaalde subgroep van borderline hypertensieve patiënten lijkt deze laatste veronderstelling juist te zijn, aangetoond werd nl. dat borderline hypertensieve patiënten met een hoge plasma renine activiteit een toegenomen perifere weerstand hebben, die tot stand komt middels neurogene invloeden (Esler et al., 1975).

Bij patiënten met een borderline hypertensie werd aangetoond dat er sprake is van een verminderd plasmavolume (Jullus et al., 1971c). Deze situatie is vergelijkbaar met die van patiënten met een hypertensie, waarbij aangetoond werd dat de verdeling van lichaamswater abnormaal is, in die zin dat er een toename is van extracellulair vocht ten koste van het intravasaal volume (Tarazi et al., 1968).

De bloeddrukregulatie is een zeer complex gebeuren waarbij een groot aantal organen en orgaansystemen een rol spelen. Hun onderlinge samenhang wordt gewaarborgd middels een aantal regelsystemen. Zo zal een optredende verandering in de circulatie een groot aantal regelsystemen in gang zetten. Bij een patient met een langer bestaande hypertensie is de kans dat de primaire oorzaak van de dysregulatie nog te detecteren is bjizonder gering. Met betrekking tot een studie, waarin gezocht wordt naar de oorzaak van hypertensie, lijkt het daarom voor de hand le liggen als studie-object proefpersonen te kiezen waarbij de hypertensie nog in een begintase verkeert. Daarom werden jonge borderline hypertensieven gevraagd in deze studie te participeren. Om in redelijke tijd voldoende vergelijkbare proefpersonen te krigen werd er gekozen voor mannen, daar zoals eerder beschreven borderline hypertensie in de jonge leeftijdsgroep meer voorkomt bij mannen dan bij vrouwen. Daar er een aantal argumenten bestaat om te veronderstellen dat een stoornis in het autonome zenuw- 
stelsel een rol speelt in de genese van hypertensie, werd een aantal aspecten van het autonome zenuwstelsel bestudeerd. In hooldstuk III zal nader worden ingegaan op de relatie van het autonome zenuwstelsel met de bloeddrukregulatie. 


\section{Literatuur}

1. Alameda County Blood Pressure Study.

State of California Department of Public Health, Berkely, 1968.

2. Basch, S.S.R. von:

Einige Ergebnisse der Blutdruckmessung an Gesunden und Kranken. Z.Klin.Med. 3:512, 1881.

3. Beevers, D.G., Fairman, M.J., Hamilton, M., and Harpur, J.E. : Antihypertensive treatment and the course of established vascular disease. Lancet I: 1407, 1973.

4. Berglund, G., Anderson, $O$. and Wilhelmsen, L. :

Prevalence of primary and secondary hypertension: studies in a random population sample.

Brit.Med.J. 2: 554, 1976.

5. Berglund, $G$., Andersson, $O$. and Wilhelmsen, $L$. :

Treatment of hypertension in the community. A preliminary report.

Acta Med. Scand. 202, Suppl. 606: 11, 1977.

6. Berglund, G., Sannerstedt, R., Andersson, O., Wedel, H., Wilhelmsen, L., Hansson, L., Sivertsson, R., Wikstrand, J.:

Coronary heart disease after treatment of hypertension.

Lancet I: 1, 1978.

7. Bøe, J., Humerfelt, S. and Wedervang, F.:

The blood pressure in a population: blood pressure readings and height and weight determinations in the adult population of the city of Bergen.

Acta Med. Scand. 321, suppl.: 1, 1957.

8. Breckenridge, A., Dollery, C.T. and Parry, E.H.O.

Prognosis of treated hypertension.

Quart J.Med. 39: 411, 1959.

9. Brenneke, H.J., Fuhlroth, H. and Sparr, K.D.:

Investigation of the course in subjects with primary borderline hypertension over a period of four years (Germany).

Doctoral Dissertation, University of Berlin, 1975.

10. Breslin, D.J., Gifford Jr., R.W. and Fairbairn, I.F.:

Essential hypertension, a 20-year follow-up study

Circ. $33: 87,1966$.

11. Bright, R. :

Reports of medical cases selected with a view of illustrating symptoms and cure of disease by a reference to morbid anatomy.

Band 1. Longman, Rees Orme, Brown and Green. London 1827.

12. Brown F.J. and Dodds, G.H.:

The remote prognosis of the toxaemias of pregnancy.

J.Obstet. Gynaecol. Br.Commonw. 46 : 443, 1939. 
13. Brown, F.J. and Shemack, D.R.

Chronic hypertension following pre-eclamptic toxaemia. The influence of familial hypertension on its causation.

J.Obstet.Gynaecol.Br.Commonw. $63: 677,1956$.

14. Carter, A.B.

Hypotensive therapy in stroke survivors.

Lancet 1: $485,1970$.

15. Dahl, L.K., Heine, M and Tassinari, L.;

Elfects of chronic excess salt ingestion. Evidence that genetic factors play an important role in susceptibility to experimental hypertension.

J.Exp.Med. 115: 1173, 1962.

16. Dawber, T.R. Kannel, W.B. and Lyell, L.P.:

An approach to longitudinal studies in a community: The Framingham Study.

Ann.N.Y.Acad.Sci. $107: 539,1963$

17. Dawber, T.R. Kannel, W.B., Kagen, A., Donabedian, R.K., McNamara,

P.M., and Pearson, G.:

Environmental factors in hypertension.

In: The Epiderriology of Hypertension (Proc. Intern. Symp.), edited by J. Stamler, R. Stamler and T.M. Pullman. Grune \& Stratton, New York, 1967, p. 255.

18. Ellis, C.N and Julius, $S$,

Role of central blood volume in hyperkinetic borderline hypertension Br. Heart J. 33:450, 1973.

19. Esler, M.D., Julius, S., Randall, O.S., Ellis, C.N., and Kashima, T.:

Relation of renin status to neurogenic vascular resistance in borderline hypertension.

Am. J. Cardiol. 36: 708, 1975.

20. Evans, W.:

Hypertonia or uneventful high blood pressure.

Lancet II: 53,1957

21. Frohlich, E.D., Emmot, C., Hammersten, J.E., Linehan, W.M., Pollack, D., and Horsley, A.W.:

Evaluation of the initial care of hypertensive patients.

JAMA 218: 1036, 1971 .

22. Gordon, T. and Devine, B.

Hypertension and hypertensive heart disease in adults. United States 1960-1962.

National Center for Health Statistics, P.H.S. Publ 1000 , ser. 11, Nr. 13 , 1966.

23. Gordon, T. and Kannel, W.B. (eds):

An epidemiological investigation of cardiovascular disease: The Framingham Study.

USDHEW; Secs. 1-27, 1968-1971.

24. Greminger, P., Vetter, W., Zimmerman, K., Beckerhoff, R., Siegenthaler, W.:

Primäre und sekondäre Hypertonie in einem poliklinischen Patientengut.

Schweiz.med. Wschr. $107: 605,1977$. 
25. Harrington, M., Kincaid-Smith, P. and McMichel, J. :

Results of treatment in malignant hypertension. A seven-year experience in 94 cases.

Br.Med.J. $2: 969,1959$.

26. Heyden, S., Bartel, A.G., Hames, L.G., and McDonough, J.R.:

Elevated blood pressure levels in adolescents: Evans County, Georgia. seven-year follow-up of 30 patients and 30 controls.

JAMA 209: 1683, 1969 .

27. Holme, I. and Waaler, H.Th. :

Five-year mortality in the city of Bergen (N) according to age, sex and blood pressure.

Acta Med.Scand. 200:229, 1976.

28. Hypertension Detection and Follow-up Program Cooperative Group:

Five-year findings of the Hypertension Detection and Follow-up Program. 1. Reduction in mortality of persons with high blood pressure, including mild hypertension.

JAMA $242: 2562,1979$.

29. Jullus, S., Harburg, E., McGinn, N.F., Keyes, J., and Hoobler, S.W.:

Relation between casual blood pressure readings in youth and at age 40 : a retrospective study.

J.Chron. Dis. $17: 397,1964$.

30. Julius, S. and Schork, M.A.:

Borderline hypertension: a critical review.

J.Chron. Dis. 23: 723, 1971.

31. Julius, S., Pascual, A.V. and London, R.:

Role of parasympathetic inhibition in the hyperkinetic type of borderline hypertension.

Circ. $44: 413,1971 \mathrm{a}$.

32. Julius, S., Pascual, A.V., Sannerstedt, R., and Mitchell, L.:

Relationship between cardiac output and peripheral resistance in borderine hypertension.

Circ. $43: 382,1971 \mathrm{~b}$.

33. Julius, S., Pascual, A.V., Reilly, K., and London, R.:

Abnormalities of plasma volume in borderline hypertension.

Arch.Intern.Med. $127: 116,1971 \mathrm{C}$.

34. Julius, S.:

Classification of hypertension.

In: Hypertension p. 9, 1977 (eds. Genest, J., Koiw, E. Kuchel, O.)

35. Kannel, W.B., Brand, N., Skinner Jr., J.J., Dawber, T.R., and McNamara, P.M. :

The relation of blood pressure and development of hypertension.

Ann.Intern.Med. $67: 48,1967$.

36. Kannel, W.B., Schwartz, M.J. and McNamara, P.M.

Blood pressure and risk of coronary heart disease: The Framingham Study.

Dis.Chest. $56: 43,1969$.

37. Kannel, W.B., Wolf, P.A., Verter, J.:

Epidemiologic assessment of the role of blood pressure in stroke: The Framingham Study.

JAMA 214: $301,1970$. 
38. Kannel, W. B., Gordon, B.T. and Schwartz, M.H.:

Systolic vs diastolic blood pressure and risk of coronary heart disease: The Framingham Study.

Am.J.Cardiol. $27: 335,1971$

39. Kannel, W.B., Castelli, W.P. McNamara. P.M

Role of blood pressure in the development of congestive heart failure:

The Framingham Study.

N.Engl.J.Med. $287: 781,1972$.

40. Kannel, W.B. and Dawber, T.R.

Hypertension as an ingredient of a cardiovascular risk profile.

Br.J.Hosp.Med. 4: 508, 1974.

41. Keith, N.M., Wagener, H.P. and Barker, N.W.:

Some different types of essential hypertension: their course and prognosis.

Am.J.Med.Sci. $197: 332,1939$

42. Kooperstein, S.I. Schifrin, A. and Leahy, T.J.:

Level of initial blood pressure and subsequent development of essential hypertension: a 10 and 15 year follow-up study.

Am.J.Cardiol. 10:416, 1962.

43. Lancet Editiorial:

Salt and Hypertension.

Lancet I: $1325,1975$.

44. Levy, R.L., Hillman, L.L., Stoud, W.D., and White, P.D.:Transient hypertension: its signifiance in terms of later development of sustained hypertension and cardiovascular-renal disease.

and cardiovascular-renal disease.

JAMA 126: 829, 1944.

45. Lew, E.A.:

Blood pressure and mortality: life insurance experience. In: The Epidemiology of Hypertension, eds. J. Stamler, A. Stamler and T.N. Pullman.

Grune \& Stratton, New York, 1967, p. 392

46. Mackenzie, L.F. and Shepherd, P.:

The significance of past hypertension in applicants later presenting normal average blood pressures.

Proc.Assoc.Life ins. Med.Dir.Am. 24:157, 1937

47. Moeller, J. and Heyder, O.:

Die labile Blutdrucksteigerung.

Z. Kreislaufforsch. 48:413, 1969

48. Major, R.H. :

The history of taking blood pressure.

Ann.Med.Hist. N.S. 2: 47, 1930.

49. Mathewson, F.A. :

Blood pressure in Canadian aviators : a fifteenth year report.

Trans.Assoc.Life Ins.Med.Dir.Am. 50: 53, 1957.

50. Mathisen, H.S., Loken, H. Brox, D., and Stenback, O. :

The prognosis in long term treated and untreated essential hypertension. Acta Med. Scand. 185 :

253, 1969. 
51. Metropolitan Life Insurance Company:

Blood pressure: insurance experience. (A series of articles reported from the Statistical Bulletin. Metropolitan Life Insurance Company).

Metropolitan Life Insurance Company. New York, 1961.

52. Mohamed, F.:

The etiology of Bright's disease and the prealbuminuric stage.

Med.-Chir, Trans. 2nd Series 39:197, 1874.

53. The National High Blood Pressure Education Program:

U.S. DHEW PUbl. Nr. (NIH) $74-593,1973$.

54. Paffenbarger Jr., R.S., Thorne, M.C. and Wing, A.L.

Chronic disease in former college students. VIIl. Characteristics in youth predisposing to hypertension in later years.

Am.J.Epidemiol. 88: 25, 1968.

55. Paul, O. and Osttelt, $A$, :

Epidemiology of hypertension

Prog.Cardiovasc. Dis. 8: 106, 1965.

56. Paul, O:

Risk of mild hypertension: a ten year report.

Br. Heart J. 33 (Suppl.): 116, 1971

57. Paul, O.:

A survey of the epidemiology of hypertension: 1964-1974.

Mod.Concepts Cardiovasc. Dis. $43: 99,1974$.

58. PHS PUBL:

Hypertension and hypertensive heart disease in United States $1960-$ 1962

PHS PUBL, 1000 , ser. 11, Nr. 13, 1966.

59. Platt, R. :

Heridity in hypertension.

Lancet I: 899, 1963

60. Prineas, R.J., Stephens, W.B. and Lovell, R.R.H. :

Blood pressure and its treatment in the community: the Albury blood pressure study.

Med.J.Aust. 1: 5, 1973.

61. Prior, I.A.M. and Evans, J.C.:

Sodium intake and blood pressure in Pacific populations.

Isr.J.Med.Sci. 5 : 608, 1969

62. Sarre, $H$. und Lindner, $E$. :

Prognose der arteriellen Hypertonie entsprechend Blutdruck und Augenhintergrundveränderungen.

Klin.Wschr. 26: 102, 1948.

63. Schottstedt, M.F. and Sokolow, M. :

The natural history and course of hypertension with papilledema (malignant hypertension).

Am. Heart J. 45: 331, 1953.

64. Shaper, A.G. (ed.):

Symposion on blood pressure and hypertension in Africa. (Sponsored

by the World Health Organization)

East Afr.Med.J 46 (5) : 1969. 
65. Shurtleff. 0 :

Some characteristics related to the incidence of cardiovascular disease and death: The Framingham Study, 18-year follow-up.

U.S. DHEW, Pub. Nr. (NIH) 74-599, sec. 30, 1974.

66. Sokolow, M, and Perloff, D, :

The prognosis of essential hypertension treated conservatively

Circ. $23: 697,1961$

67. Stamler, J., Lindberg, A., Berkson, D.M., Shaffer, A., Miller, A., and Poindexter, A. :

Hypertension VII (Proc.Coun. High Blood Press.Res.).

American Heart Assocation, New York, p. 23, 1958.

68. Storm-Mathisen, H., Loken, H., Brox, D., and Stokke, H. :

The prognosis in essential hypertension.

Scand.J.Clin.Lab.Invest 17 (Suppl 84):257, 1965.

69. Tarazi, R.C. Frohlich, E.D. and Dustan, H.P.:

Plasma volume in man with essential hypertension.

N.Engl.J.Med. $278: 762,1968$

70. Thomson, K.J.:

Some observations on the development and course of hypertensive vascular disease

Proc.Ann.Meet.Med.Sect.Am.Life Convention 38: 85, 1950.

71. Veterans Administration Cooperative Study Group on Antihypertensive Agents:

Effects of treatment on morbidity in hypertension.

1. Results in patients with diastolic blood pressures averaging 115 through $129 \mathrm{~mm} \mathrm{Hg}$. JAMA 202: $1028,1967$.

72. Veterans Administration Cooperative Study Group on Antihypertensive Agents :

Effects of treatment on morbidity in hyperiension.

11. Results in patients with diastolic blood pressures averaging 90 through $114 \mathrm{~mm} \mathrm{Hg}$. JAMA 213: 1143, 1970.

73. Volkov, V.S., Dragoshanskaya, A.V. and Shur, A.G. :

On risk factors in the development of hypertensive disease.

Kardiologiia (Moskva) 12:65, 1972.

74. Wilhelmsen, L., Berglund, G. and Werkö, L. :

Prevalence and management of hypertension in a general population sample of Swedish men.

Prev.Med. 2: 57, 1973.

75. World Health Organization:

Techn.Rep. 168, 1958.

76. World Health Organization:

Techn.Rep. 231. 1962. 


\section{Hoofdstuk III. Hypertensie en het autonome zenuwstelsel}

\section{- De bloeddrukregulatie met speciale aandacht voor de autonome zenuwreflexen}

De arteriële bloeddruk wordt bepaald door het hartminuutvolume en de weerstand die het door de vaten stromende bloed ondervindt. Deze relatie kan worden weergegeven door de volgende vergelijking: arteriële druk = hartminuutvolume $x$ totale perifere weerstand (Poiseulle, 1828; Hagen, 1839). ledere toe- of afname van het hartminuutvolume en/of de perifere weerstand zal een verandering van de bloeddruk tot gevolg hebben. Het vermogen van het cardiovasculaire systeem zorg te dragen voor een adequate doorstroming van de organen hangt $o$ a. af van de vulling van de vaten, de eigenschappen van de vaatwand en de pomplunctie van het hart. Deze intrinsieke eigenschappen van het cardiovasculaire systeem worden voor een belangrijk deel bepaald door andere mechanismen die daardoor een belangrijke rol spelen in de bloeddrukregulatie. Een aantal van deze mechanismen kan snel werken, zij zijn voornamelijk betrokken bij de korte termin regulatie van de bloeddruk. $\mathrm{Zij}$ trachten van buiten opgeroepen bloeddrukveranderingen snel te corrigeren en zorgen voor snelle aanpassing van de circulatie als het organisme daar onder bepaalde omstandigheden behoefte aan heeft. Als dergelijke systemen, die snel kunnen reageren, zijn te beschouwen: de lokale controle van de bloedstroom door de weefsels zelf, een aantal humorale mechanismen en de nerveuze controle door he: autonome zenuwstelsel. Als veel langzamer werkend systeem noemen we het renale vloeistofexcretie mechanisme. Hoewel langzamer werkend dan de hierboven vermelde mechanismen is het renale vloeistofexcretie mechanisme van groot belang voor de bloeddrukregulatie daar dit systeem doorgaat met corrigeren zolang er geen evenwicht bestaat tussen vloeistofopname en vloeistofafgifte. Hierbij is vooral de relatie tussen arteriele bloeddruk en urine-excretie van belang omdat een geringe verandering van de bloeddruk al een grote verandering in de urine-excretie veroorzaakt (Selkurt, 1951; Borst en Borst-De Geus, 1963; Coleman et al., 1972; Guyton et al., 1974).

Elk van de genoemde mechanismen reageert op bepaalde stimuli met een corrigerende activiteit. Doordat de verschillende regulatiemechanismen bij een bloeddrukverandering gelijktijdig in werking worden gezet, is de regulatie van de arterielle bloeddruk als geheel zeer complex van aard. Daarbij komt nog dat de activiteit van elk van deze mechanismen wordt beinvloed door de activiteit van de andere tegelijkertijd functionerende mechanismen. Op de afzonderlijke mechanismen zal hier niet nader ingegaan worden. In tabel 2 worden de belangrijkste thans bekende regulatiemechanismen weergegeven (Struyker Boudier en Rahn, 1979), terwijl fig. 1 de schematische weergave is van de wijze waarop een verandering in de bloeddruk elk van deze regulatiemechanismen in werking zet (Guyton et al. 1974). 







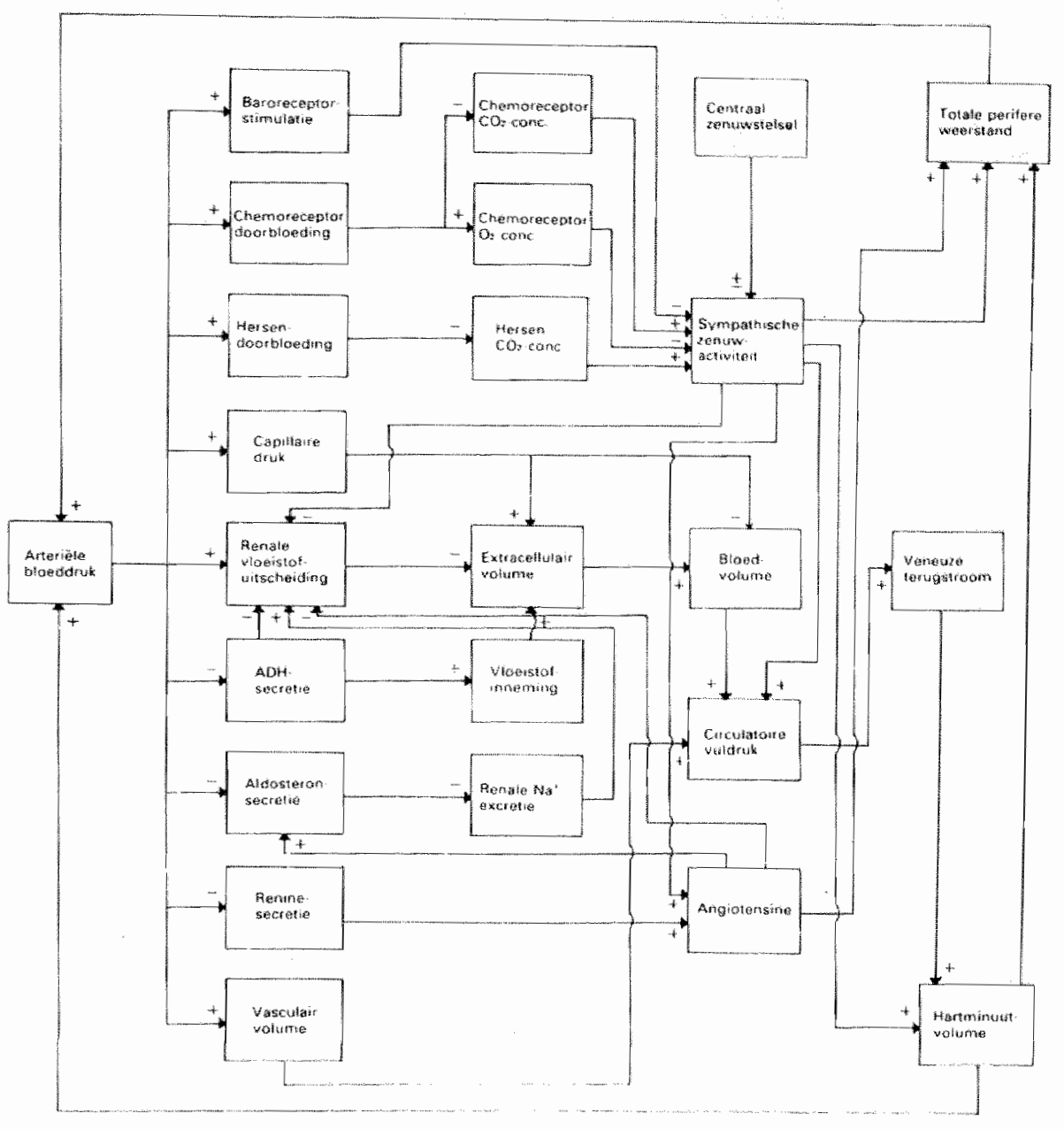

\section{Figuur 1}

Blokdiagram van de belangrijkste relaties tussen de verschillende onderdelen van het bloeddrukregulatiesysteem. Een + bi een pijl tussen iwee blokken betekent dat een verhoging in de waarde van het ene, een verhoging in het andere tot gevolg heeft, terwil een - duidt op een negatief effect (Naar Guyton e.a. 1974). 
Nadat nu in grote lijnen het principe van de bloeddrukregulatie geschetst is, zal op én van de snel functionerende regulatiemechanismen dieper ingegaan worden en wel op de nerveuze controle door het autonome zenuwstelsel. Dit daar later in dit proefschrift een studie wordt beschreven aangaande de rol van hel autonome zenuwstelsel in de genese van hypertensie. Het mechanisme waarlangs deze nerveuze controle tot stand komt, wordt gevormd door een complexe reflexboog, die functioneert via het principe van de negatieve 'feedback' (Edis en Shepherd, 1970). Deze reflexboog kan schematisch als volgt beschreven worden: zij bestaat uit drie gedeelten; het afferente deel waarlangs de informatie vanuit de periferie naar centraal gevoerd wordt, een centraal deel waar de binnenkomende informatie wordt verwerkt en geintegreerd en een efferent deel dat er zorg voor draagt dat de impulsen vanuit het centrale deel de effector-organen bereiken. Het afferente deel van deze reflexboog ontvangt zijn informatie van de receptoren gelegen langs de vaatboom. Met betrekking tot de bloeddrukregulatie zijn de belangrijkste receptoren de 2.9 . drukgevoelige sensoren. Deze op drukverandering reagerende receptoren zijn gelokaliseerd in het hart, de sinus caroticus, de aortaboog en andere grote vaten. De receptoren worden gestimuleerd door daar ter plaatse optredende rekking, waarna de informatie over de lokaal veranderde druk via het afferente deel van de reflexboog naar het centrale zenuwstelsel gevoerd wordt. De afferente banen van het hart en de aorta lopen via de nervus vagus, terwijl de afferente vezels van de sinus caroticus via de nervus glossopharyngeus lopen.

Bij de mens vormen de baroreceptoren de belangrijkste drukgevoelige receptoren. In verband met hun grote rol in de bloeddruktegulatie zal op deze baroreceptoren in het hierna volgende wat dieper worden ingegaan. De baroreceptoren zijn speciaal effectief bij de correctie van bloeddrukveranderingen in het drukgebied tussen 60 en $160 \mathrm{~mm} \mathrm{Hg}$. Het reflexmechanisme dat bloeddrukveranderingen corrigeert met als startpunt de baroreceptoren is een bijzonder snel werkend en effectief systeem. Veranderingen in de bloeddruk kunnen in 20 seconden voor bijna $2 / 3$ gecorrigeerd worden (Scher en Young, 1963; Sagawa en Watamabe, 1965). In de studie van Glick en Braunwald (1965) werd beschreven hoe een met behulp van vasodilatatoren teweeggebrachte bloeddrukdaling voornamelijk gecorrigeerd werd door een door de baroreceptoren opgeroepen sympathicusstimulatie. Een door vasoconstrictie opgeroepen bloeddrukstijging werd voornamelijk ongedaan gemaakt door een toename van parasympathische activiteit. Blokkerende stoffen van enerzijds het sympathische en anderzijds het parasympathische zenuwstelsel werden gebruikt om te beoordelen welk deel van het autonome zenuwstelsel verantwoordelijk was voor het tot stand komen van de corrigerende activiteil. Hedendaagse inzichten in de fysiologie van de baroreceptorreflex tonen een zeer gedifferentieerd patroon van reactiemogelijkheden, optredend als respons op veranderingen in de bloeddruk, dit zowel van het sympathische als van het parasympathische deel van het autonome zenuwstelsel (Korner et al., 1974). De hierboven vermelde studie werd zowel met honden als met mensen verricht.

Een vrij recente bevinding omtrent de baroreceptoren en de bloeddruk- 
regulatie dient hier vermeld te worden. Tot voor enige jaren werd aangenomen dat afferente denervatie van de baroreceptoren resulteerde in een zogenoemde neurogene hypertensie. Inmiddels is het evenwel duidelijk geworden dat een dergelijke ingreep slechts een korte - $\mathrm{nl}$. minder dan een dag durende - verhoging van de bloeddruk tot gevolg heeft, waarbij opgemerkt dient te worden dat de bloeddruk na de denervatie veel minder stabiel op één niveau wordt gehandhaatd als voor de denervatie (Cowley et al., 1973; Onesti et al. 1976).

Het baroreceptormechanisme is een belangrijk systeem ter stabilisering van de bloeddruk. Het draagt niet bij tot regulatie van de bloeddruk op langere termijn. Immers de baroreceptoren adapteren snel, namelijk in éen à twee dagen, aan het niveau van de bloeddruk waaraan zij zijn blootgesteld (Kezdi en Wennemark, 1958 ; Kreiger, 1970). In dit kader spreekt men over 'adaptatie' van de baroreceptoren.

Naast de baroreceptoren spelen andere receptoren onder normale fysiologische omstandigheden een minder belangrijke rol. In dit verband vermelden we de drukreceptoren gelegen in de atria van het hart en de longcirculatie (Paintal, 1971), en de chemoreceptoren (Calvelo et al., 1970) gelegen in de arcus-aortae en de beide arteriae carotides. Deze chemoreceptoren worden gestimuleerd in situaties gepaard gaande met hypoxie. Daarnaast spelen in extreme omstandigheden bepaalde receptoren gelegen in de hersenen een rol. Zij kunnen een zeer sterke sympathicusstimulatie veroorzaken in situaties waarbij er een zuurstoftekort in de hersenen is ontstaan; men duidt deze reactie aan met de term 'hersenischaemie-retlex:

De afferente informatie bereikt de vaso- en cardiomotorische controlecentra gelegen in de hersenstam. Deze vasomotorische centra staan op hun beurt onder invloed van hogere integratieve centra gelegen in de hypothalamus, het limbische systeem en de cortex cerebri /Karplus en Kreidl, 1927 ; Ranson en Magoun, 1939; Hess en Brügger, 1943: Hess, 1949; Uvnäs, 1960, Folkow et al., 1965 ; Uvnâs, 1971). Mogelijk vormen deze hogere centra de schakel tussen emotionele stimuli en de bloeddrukregulatie, zo kon aangetoond worden dat bij mentale stress onder invloed van hogere centra een sympathicusstimulatie optreedt, waarbij de perfusie van een aantal organen al naar gelang hun behoefte onder die stress toeneemt (Charvat et al., 1964).

Na integratie van de voortdurende stroom van afferente informatie die het centrale autonome zenuwstelsel bereikt vanuit de periferie en de hogere centra ontstaat er een efferente stroom naar het cardiovasculaire systeem waardoor er een continue bijstelling van de circulatie plaatsvindt al naar gelang de behoefte van het organisme op dat moment (Livingstone, 1972). De informatie van centraal naar perifeer wordt doorgegeven door middel van efferente autonome vezels, die bestaan uit sympathische en parasympathische banen.

De efferente parasympathische component wordt gevormd door een netwerk van vezels naar het hart, die bij stimulatie een vermindering van de hartfrequentie en een daling van de contractiekracht van de hartspier veroorzaken. 
Met behulp van de histofuorescentie techniek volgens Falck et al. (1962) kunnen de adrenerge vezels aangetoond worden. Door middel van deze techniek was het mogelik de efferente sympathische vezels op tal van plaatsen langs de vaatboom en het hart aan te tonen, hetgeen goed in overeenstemming is met het idee dat het efferente sympathische deel van het autonome zenuwstelsel een belangrijke rol speelt in de regulatie van het cardiovasculaire systeem (Norberg, 1967 ; Burnstock el al., 1970). Speciaal de kleinere arteriolen, waarvan bekend is dat zij een uiterst belangrijke rol spelen in de weerstandsregulatie, zijn rijkelijk voorzien van adrenerge vezels (Meelander en Johansson, 1968). Ook ter plaatse van de baroreceptoren worden adrenerge vezels gezien (Reis en Fuxe, 1968). Hoewel hun exacte functie daar ter plaatse nog niet geheel opgehelderd is, lijkt het waarschinnlijk dat deze vezels de gevoeligheid van de baroreceptoren moduleren. Ter plaatse van het hart worden tevens talrijke efferente sympathische vezels aangetroffen, zij oefenen aldaar een stimulerend effect uit. Op de werking van de parasympathische en de sympathische vezels op de verschillende delen van het cardiovasculaire systeem zallater in dit hoofdstuk uitvoeriger teruggekomen worden.

Alhier dient nog vermeld te worden dat het sympathisch zenuwstelsel tevens verantwoordelijk is voor de controle van de afgifte van de catecholamines uit de bijnier (Malmejac, 1964). Het hart en de bloedvaten bevatten receptoren voor de catecholaminen en kunnen daardoor beïnvloed worden zowel door het noradrenaline afkomstig vit de zenuwuiteinden als door de catecholaminen afkomstig uit de bijnier.

\section{- De fysiologische anatomie van het efferente deel van het autonome zenuwstelsel, voor zover van belang voor de circulatie}

De cellichamen van de efferente sympathische vezels liggen in de hersenstam. Van hieruit daait hel proximale neuron af. Het proximale neuron vormt een synaps ter plaatse van de sympathische ganglia gelegen langs de thoraco-lumbale wervelkolom. Tezamen vormen deze ganglia de sympathische grensstreng. Van hieruit daalt het distale neuron af naar zijn effectororgaan. Het distale neuron wordt gestimuleerd door acetylcholine dat vrijkomt uit het zenuwuiteinde van het proximale neuron. Het noradrenaline dat vrijkomt uit het adrenerge zenuwuiteinde stimuleert uiteindelijk de receptoren van het effectororgaan. Hier zal later in dit hoofdstuk op teruggekomen worden.

De sympathische innervatie van de bijnier verloopt lets afwijkend. De presynaptische vezels lopen zonder synaps te vormen door tot in het bijniermerg, waar ze direct eindigen bij speciale cellen die adrenaline en noradrenaline kunnen secerneren. Embryologisch zijn deze cellen afkomstig uit zenuwweefsel, zij zijn analoog aan de postganglionaire sympathische neuronen gelegen in het overige deel van het efferente sympathische zenuwstelsel buiten het bijniermerg (Guyton, 1976).

Van het parasympathische deel van het autonome zenuwstelsel zijn, in verband met de bloeddrukregulatie, voornamelijk de banen naar het hart van belang. Het parasympathische systeem heeft net als het sympathische 
zowel pre-als postganglionaire vezels. De preganglionaire vezels, die het hart innerveren, schakelen evenwel niet zoals de preganglionaire sym. pathische vezels over in een ganglion maar lopen door tot in het hart. De efferente parasympathische vezels bereiken het hart via de nervus vagus. In het hart zelf liggen de postganglionaire parasympathische neuronen. De preganglionaire neuronen vormen een synaps met deze postganglionaire neuronen en kleine postganglionaire neuronen met een lengte van een millimeter tot enkele centimeters verspreiden zich door de hartspier. Zowel de pre- als de postganglionaire parasympathische neuronen secerneren acetylcholine.

In de hierna volgende paragraaf zal nader ingegaan worden op de functie en het metabolisme van de neurotransmitters acetylcholine en noradrenaline.

\section{- De neurotransmitters van het autonome zenuwstelsel en hun meta- bolisme}

De neurotransmitter van de postganglionaire sympathische neuronen is noradrenaline; de neurotransmitter van zowel de preganglionaire sympathische neuronen als van de pre-en postganglionaire parasympathische neuronen is het acetylcholine.

Allereerst zullen we in het kort noradrenaline bespreken daarna het acetylcholine. Voor een uitgebreide discussie aangaande beide neurotransmitters verwijs ik naar een aantal sludies (Ahlquist, 1948; Hebb, 1970; Axelsson, 1971 ; Geffen en Livett, 1971 ; Costa et al., 1972; De Potter et al., 1972; Smith, 1972 ; Fonnum, 1973 ; Jenkinson, 1973; Nickerson, 1973; Häggendal, 1974; Karlin, 1974; Molinoff et al., 1974; De Robertis en Schacht, 1974; Winkler et al., 1974; Paton, 1975). Uitgangspunt voor de synthese van het noradrenaline is het essentiële aminozuur L-tyrosine. Het L-tyrosine wordt gehydroxyleerd door het enzym tyrosinehydroxylase waardoor er dihydroxyphenylalanine (DOPA) ontstaat. Deze stof wordt omgezet tot L-hydroxyphenylethylamine (DOPAMINE) onder invioed van dopadecarboxylase. Het gevormde dopamine wordt opgenomen in de vesikels van de sympathische zenuwuiteinden, alwaar het door dopaminebeta-hydroxylase (DBH) wordt omgezet in noradrenaline. In een inactieve vorm wordt een deel van het nieuw gevormde noradrenaline, gebonden aan ATP, in de vesikels opgeslagen, daarnaast bestaat er een intracellulaire voorraad vrij, niet gebonden en niet opgeslagen, noradrenaline. De vorming en de afgifte van noradrenaline door het terminale zenuwuteinde staan onder invloed van de zenuwactiviteit van het postganglionaire neuron.

Alleen in het bijniermerg en mogelijk op sommige plaatsen in de hersenen (Hökfelt et al., 1974) kan noradrenaline onder invloed van phenylethanolamine-N-methyl-transferase (PNMT) (Axelrod en Weinshilboum, 1972) omgezet worden in adrenaline. De inductie van PNMT en daardoor de vorming van adrenaline staan onder invloed van cortisol dat het bijniermerg bereikt via een intra-adrenaal poortadersysteem (Pchorecky en Wurtman. 1971) 
Na stimulatie van het biniermerg of van de sympathische zenuwuiteinden komen de catecholaminen vrij door middel van exocylose, bij dit proces komt tevens DBH vrij (Weinshiboum et al, 1971). Het vrijgekomen noradrenaline diffundeert in de synapsspleet en bereikt de specifieke receptoren van de effectorcellen. Een relatief klein deel van de neurotransmitter komt terecht in de circulatie en wordt via de nieren uitgescheiden of wordt in de lever gemetaboliseerd. Het allergrootste deel van het vrijgekomen noradrenaline wordt weer opgenomen in het terminale zenuwuiteinde. Door dit proces ontstaat er een efficient systeem waarbij voorkomen wordt dat er een overmaat aan transmitter ontstaat in de synapsspleet terwijl er in de terminale zenuwuteinden steeds voldoende noradrenaline aanwezig is. Bovendien is recent aangetoond dat ook via een presynaptisch receptormechanisme de adrenerge transmissie wordt gereguleerd (Starke, 1973).

De uit de bijnier vrijgekomen catecholaminen worden aan de bloedstroom atgegeven en bereiken via de circulatie hun effectororganen. De uit de bijnier afkomstige catecholaminen functioneren niet als neurotransmitter. maar als humoraal actieve stoffen

De catecholaminen worden op twee verschillende wijzen gemetaboliseerd.

Ten eerste: het grootste deel van de catecholaminen word intraneuraal geinactiveerd (Brunjes, 1964). Onder invloed van het enzym mono-amine oxydase (MAO) treedt er oxidatieve desaminering op, waardoor er 3,4-dihydroxy-amandelzuur ontstaat. Dit 3,4-dihydroxy-amandelzuur wordt vervolgens extraneuraal onder invloed van catechol-O-methyltransterase (COMT) omgezet in 3-methoxy-4-hydroxy-amandelzuur (VMA), dat in de urine wordt uitgescheiden.

Ten tweede: een veel kleiner deel van de catecholaminen wordt extraneuraal geinactiveerd; door methylering onder invloed van COMT ontstaan als afbraakprodukten van het adrenaline en het noradrenaline respectieveljk het metanephrine en het normetanephrine. De metanephrinen worden door MAO verder afgebroken tol VMA of onveranderd via de nieren uitgescheiden.

De neurotransmitter van het parasympathische zenuwstelsel is acetylcholine. Deze stof wordt aangemaakt in het uiteinde van de cholinerge zenuwuiteinden en wel in hel axoplasma van de neuronen. Het acetylcholine ontstaat uit acetyl-CoA en choline onder invloed van cholineacetylase waarna de nieuw gevormde acetylcholine wordt opgenomen in de vesikels van de zenuwuiteinden. Als een actiepotentiaal het terminale zenuwuiteinde bereikt, neemt de permeabiliteit van de neuronale membraan voor calciumionen toe, waardoor calciumionen van extraneuronaal diffunderen naar intraneuronaal. Deze calciumionen interfereren met de vesikels die tegen de neuronale membraan aanliggen, waarna de vesikels fuseren met de membraan en hun inhoud - het acetylcholine - vrijkomt. Het acetylcholine bereikt zijn specifieke receptor waardoor de effectorcel geactiveerd wordt.

Het allergrootste deel van het vrijgekomen acetylcholine wordt onder invloed van het enzym cholinesterase gesplitst in acetaat-ionen en choline. 
Hel cholinesterase is zowel aanwezig in de terminale zenuwuiteinden als aan het oppervlak van het receptororgaan. Het extraneuraal gevormde choline wordt weer opgenomen in het terminale zenuwuiteinde waar het weer gebruikt wordt voor de synthese van acetylcholine.

Hoewel hel grootste deel van het acetylcholine binnen een fractie van een seconde na de excretie al afgebroken is, blift er soms een kleine hoeveelheid acetylcholine gedurende enkele seconden bestaan, zodat zeer kleine hoeveelheden van de neurotransmitter soms diffunderen tot in de onmiddellijke omgeving. Hier bevindt zich een bepaald soort cholinesterase. namelijk de zogenaamde serumcholinesterase, die in enkele seconden deze kleine hoeveelheid acetylcholine afbreekt. Door deze processen is de levensduur van de door de terminale zenuwuiteinden vrijgegeven acetyl. choline slechts zeer kort en varieert van fracties van seconden tot maximaal enkele seconden.

\section{- Effecten van het autonome zenuwstelsel op de circulatie.}

Op verschillende wijzen kan het autonome zenuwstelsel de circulatie beinvloeden. De belangrijkste thans bekende relaties tussen het sympathische en parasympathische zenuwstelsel enerzijds en hel cardiovasculaire systeem anderzijds worden weergegeven in fig. 2 (Struyker Boudier en Rahn, 1979).

De activiteit van het hat staat zowel onder invloed van het parasympathische als het sympathische deel van het autonome zenuwstelsel. Daarbil beïnvloedt het sympathische zenuwstelsel de circulatie nog op andere, buiten het hart gelegen, plaatsen in het lichaam. Allereerst zal de invloed van zowel het sympathische als het parasympathische zenuwstelsel gememoreerd worden, waarna de beïnvloeding van de circulatie door het sympathische zenuwstelsel op andere plaatsen dan het hart besproken zal worden.

Parasympathische beïnloeding van de activiteil van hel hart treedt uitsluitend op via de cholinerge vezels die het hart bereiken, daarentegen kan sympathische beinvloeding van het hart optreden zowel door middel van de adrenerge vezels die het hart innerveren als door de circulerende catecholaminen die door de bijnier, na sympathicusstimulatie van dit orgaan, aan de circulatie worden afgegeven. Daar de effecten op het hart. opgeroepen door het sympathische deel van het autonome zenuwstelsel tegenovergesteld zijn aan die van het parasympathische zenuwstelsel, zullen beide invloeden naast elkaar besproken worden.

De regulatie van het hartminuutvolume komt tot stand langs twee wegen. Het belangrijkste regelmechanisme is de autoregulatie beschreven in de wet van Frank-Starling. Daarnaast spelen invloeden vanuit het autonome zenuwstelsel een rol. In het hart worden zowel sympathische als parasympathische vezels aangetroffen. Beide atria zijn rijkelijk voorzien van zowel adrenerge als cholinerge vezels. De situatie is anders ter plaatse van de ventrikels waar de sympathische vezels de parasympathische in aantal ver overtreffen. Het autonome zenuwstelsel kan zowel de hartfrequentie als de contractiekracht van het hart beinvloeden. Parasympathische stimulatie 


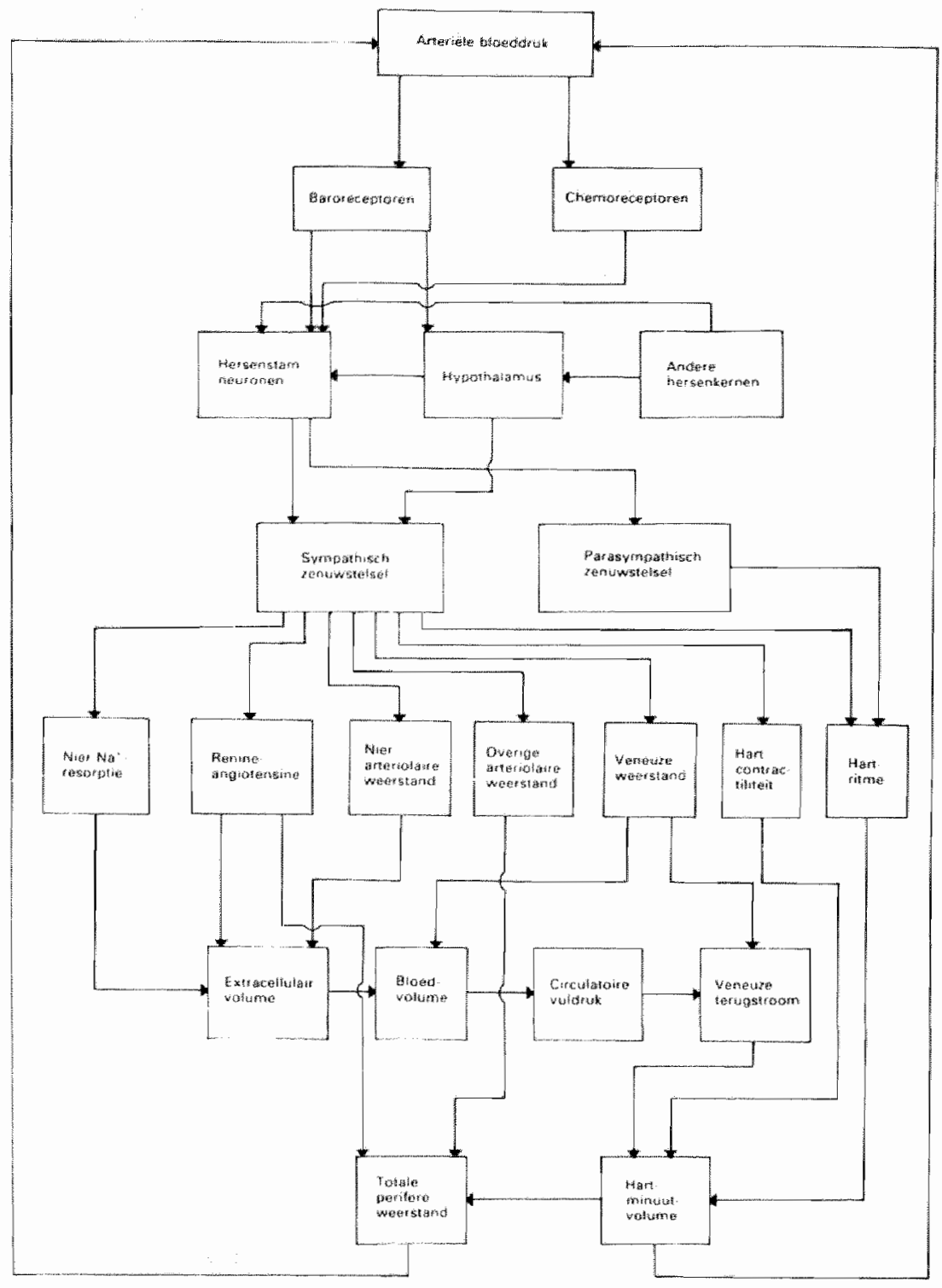

\section{Flguur 2}

Blokdiagram van de belangrijkste relaties tussen het autonome zenuwstelsel en het cardiovasculaire systeem. 
doet de hartfrequentie dalen terwijl sympathische stimulatie het tegenovergestelde bewerkstelligt. Onder maximale vagusstimulatie kan de hartfrequentie dalen tot 20 a 30 slagen per minuut. Hartfrequenties van meer dan 200 slagen per minuut kunnen gezien worden tijdens maximale sympathicusstimulatie. Onder normale rustcondities ontladen de sympathische vezels zich op dusdanige wijze dat de contractiekracht van het myocard word gehandhaafd op een niveau dat ongeveer $20 \%$ hoger ligt dan de contractiekracht die gezien zou worden zonder sympathische stimulatie. Niet alleen door parasympathische stimulatie, maar ook door vermindering van sympathische activiteit kan het autonome zenuwstelsel de contractiekracht van de ventrikels doen afnemen. Bij maximale sympathische stimulatie kan de contractiekracht van het myocard met ongeveer $100 \%$ toenemen. Maximale parasympathische stimulatie veroorzaakt een afname van de contractiekracht met ongeveer $30 \%$.

Een toename van sympathische activiteit en/of een afname van parasympathische activiteit zal een toename van het hartminuulvolume veroorzaken. Deze toename zal veroorzaakt worden door zowel een stijging van de hatfrequentie als van de contractiekracht. Andersom zal een afname van de sympathische stimulatie en/of een toename van de parasympathische activiteit het tegenovergestelde bewerkstelligen. Bij gelijkblivende totale perifere weerstand zal een toename van het hartminuutvolume gepaard gaan met een stijging van de bloeddruk en een afname van het hartminuutvolume met een daling van de bloeddruk.

Zoals hierboven gememoreerd kan sympathische beinvloeding van het hart tot stand komen door middel van de adrenerge vezels die het hart innerveren maar daarnaast ook door de circulerende catecholaminen die onder sympathicusstimulatie door de bijnier aan de bloedstroom zijn afgegeven. Het lijkt daarom zinvol de effecten van adrenaline en noradrenaline op het cardiovasculaire systeem in grote lijnen te beschrijven.

Op het geisoleerde hart hebben adrenaline en noradrenaline beide een positief inotroop en chronotroop effect. In het intacte organisme veroorzaakt de pure vasoconstrictor noradrenaline zowel een systolische als een diastolische bloeddrukstijging, hetgeen aanleiding geeft tot een reflexbradycardie, waarbij het hartminuutvolume uiteindelijk onveranderd blijt of zelfs licht daalt. Het adrenaline veroorzaakt een matige vasoconstrictie van de huid-en niervaten, maar tevens een vasodilatatie van de weerstandsvaten in de skeletspieren, waardoor het netto effect een vermindering van de totale perifere weerstand is. In tegenstelling tot noradrenaline veroorzaakt adrenaline in het intacte organisme een stiging van het hartminuutvolume, waarbij de polsdruk groter wordt door een stijging van de systolische bloeddruk terwijl de diastolische bloeddruk gelijk blijt of licht daalt. Beide stoffen hebben nog tal van andere effecten die evenwel met betrekking tot de bloeddrukregulatie van minder belang zijn en daarom hier niet besproken worden.

Zoals in hel voorafgaande beschreven kan het parasympathische zenuwstelsel de circulatie uitsluttend beinvioeden door zijn effecten op het hart, daarentegen reguleert het sympathische zenuwstelsel de circulatie niet alleen op het niveau van het hart maar ook op andere plaatsen in het 
Ilchaam, die nu vervolgens in het kort besproken zullen worden.

Het sympathische zenuwstelsel oefent zowel effecten utt op de arterien als de venen. Het sympathische zenuwstelsel moduleert door middel van de receptoren gelegen in de wand van de venen de tonus van het veneuze vaatbed. Daardoor wordt de verdeling van bloed tussen het arteriele en het veneuze deel van de circulatie beinvloed en daardoor de vullingsdruk van het veneuze systeem. Naarmate de vullingsdruk van het veneuze deel groter is, zal er een grolere terugstroom van bloed naar het hart zijn. waardoor het harminuutvolume toeneemt. Een toename van sympathische activitet zal aan de arteriele zijde van het vaatbed, door middel van stimulering van de in de arteriolairwand gelegen receptoren, een vasoconstrictie veroorzaken, waardoor de perifere weerstand stijgt. Een onder sympathicusstimulatie optredende vasoconstrictie van de afferente nierarteriolen kan aanleiding geven tot een vermindering van de glomerulatre filtratie, hetgeen op langere termijn een toename van circulerend volume kan veroorzaken.

Een andere belangrijke weg waarlangs het sympathische zenuwstelsel door zijn effect op de nier de circulatie kan beinvloeden, wordt gevormd door de relatie die er bestaat tussen het sympathische zenuwstelsel en het renine-angiotensine-systeem. Het vrijkomen van renine uit de nieren staat sterk onder invloed van de sympathische zenuwactiviteit (Davis, 1973)

Recentelijk werd beschreven (Slick et al. 1975; Di Bona et al., 1977) dat de sympathicus door een rechtstreeks effect op de nertubulus natrium-en waterretentie kan veroorzaken, hetgeen betekent dat er via dit mechanisme een beinvloeding van het circulerende volume kan optreden. Naast deze plaatsen waar het sympathische zenuwstelsel, zoals weergegeven in fig. 2, de circulatie kan beïvloeden werd in de literatuur nog een aantal wegen beschreven langs welke het sympathische zenuwstelsel de circulatie kan beinvloeden.

Zo hebben efferente sympathische vezels invloed op de activiteit van de baroreceptoren (Masuyama, 1960). Hoe en in welke mate dit mechanisme functioneert is nog niet geheel duidelijk. Het angiotensine II likkt tevens een centrale pressoractiviteit uit te oefenen waarschijniijk via een inwerking op de area postrema, een gebled in de hersenen dat niet bekleed word door de bloedhersenbarriere. De sterkte van dit effect wordt gemoduleerd door het autonome zenuwstelsel, in die zin dat het effect groter wordt tijdens toegenomen sympathische activiteit of afgenomen parasympathische activiteil (Ferrario et al. 1972).

\section{- Langs welke wegen zou een stoornis van het autonome zenuw- stelsel een hypertensie kunnen veroorzaken?}

Zowel een stoornis in de functie van het sympathische als van het parasympathische zenuwstelsel moet in staat worden geacht een dysregulatie van de bloeddrukregulatie te kunnen veroorzaken. Voor wat betreft het parasympathische zenuwstelsel is de enige plaats waar dit deel van het autonome zenuwstelsel een belangrijke invloed op de circulatie kan uitoefenen het hart. Een te geringe activiteit van het parasympathische 
zenuwstelsel zou in staat zijn de hartfrequentie en de contractiekracht van het hart dusdanig te beinvloeden dat er, in situaties dat er sprake is van een normale sympathische activiteit ter plaatse van het hart, een hogere hartfrequentie en een grotere contractiekracht dan normaal wordt gezien. Het resultaat van deze situatie zou zijn dat mensen met een dergelijk beeld gekenmerkt worden door een snellere hartactie en een groter hartminuutvolume.

Zoals hierboven gememoreerd, zouden stoornissen in de functie van het sympathische zenuwstelsel op meerdere plaatsen in het lichaam een dysregulatie van de bloeddruk kunnen veroorzaken. Het is uit onderzoekingen van de laatste jaren duidelijk geworden dat een aantal kernen in het centrale zenuwstelsel, die betrokken zijn bij de bloeddrukregulatie, de sympathische zenuwactiviteit op bijzonder gedifferentieerde wijze kunnen besturen. Zo is het bijv. mogelijk dat vanuit bepaalde kernen in de middenhersenen de activiteit van sympathische vezels naar de huid te beinvloeden is zonder noemenswaardige veranderingen in de renale zenuwactiviteit (Ninomiya et al. 1973; Korner, 1975). Anderzijds kan de renale sympathische zenuwactiviteit selectief worden verhoogd door stimulatie van het posterieure deel van de hypothalamus. Stoornissen in de centrale regulatie van de sympathische activiteit lijken zeer wel in staat aanleiding te kunnen geven tot een totale of een 'gedifferentieerde' dysregulatie van de perifere sympathische activiteit.

De thans bekende lokalisaties waar een toename van sympathische zenuwactiviteit aanleiding zou kunnen geven tot het ontstaan van een hypertensie zijn: de arteriolen, de venen, het hart, de afferente arteriolen van de nier, het juxtaglomerulaire apparaat en de tubuli van de nier. Onder invloed van een toegenomen sympathische activiteit worden de receptoren van de gladde spieren gelegen in de arteriolaire wand gestimuleerd. De hierdoor opgeroepen vasoconstrictie veroorzaakt een stijging van de perifere weerstand, waardoor een bloeddruk verhogend effect wordt opgeroepen. Deze situatie bestaat bijv, bij een feochromocytoom, een infusie met een alpha-adrenerge stof en een stress-toestand, zoals onderdompeling van een hand in ijskoud water.

Een toegenomen sympathicustonus zal door stimulatie van de receptoren gelegen in de wand van de venen aanleiding geven tot een kleiner worden van de veneuze capaciteit. Dit heeft een verhoogde terugstroom naar het hart tol gevolg waardoor het hartminuutvolume groter zal worden.

Door een toegenomen activiteit van het sympathische zenuwstelsel zal zowel de hartfrequentie als de contractiekracht van het hart toenemen. waardoor er een stijging van het hartminuutvolume tot stand komt.

Constrictie van de afferente arteriolen van de nieren, tengevolge van een verhoogde sympathicusactiviteit, zal tot gevolg hebben dat er een vermindering van de glomerulaire filtratie tot stand komt waardoor er een retentie van natrium en water optreedt en de hoeveelheid extracellulair vocht zal toenemen.

Zoals beschreven in de voorafgaande paragraat, leidt een verhoogde sympathische activiteit tot een vermeerderde vrijmaking van renine uit de juxtaglomerulaire cellen. Dit geeft aanleiding tot een verhoogde angloten- 
sine II spiegel in het bloed met als gevolg constrictie van de arteriolen en venen en een verhoogde terugresorptie van natrium en water in de tubulus. Langs beide wegen wordt door een verhoogde angiotensine II spiegel een stijging van de bloeddruk opgeroepen.

Daarbij kan een toegenomen sympathicustonus, zoals eerder hierboven beschreven, ook nog een direct effect op de niertubulus uitoefenen waardoor er in toegenomen mate natrium en water wordt geretineerd.

Resumerend kan gesteld worden dat stoornissen in de activiteit van het autonome zenuwstelsel zeer wel in staat zijn een hypertensie te veroorzaken. in het volgende hoofdstuk zal een aantal onderzoeken beschreven worden aangaande de functie van het autonome zenuwstelsel bij mensen met een stoornis in hun bloeddrukregulatie, die geleid heeft tot een borderline hypertensie. 


\section{Literatuur}

1. Ahlquist, R.P.:

A study of the adrenotropic receptors.

Am. J.Physiol. 153: 586, 1948.

2. Axelrod, J. and Weinshilboum, R. :

Catecholamines.

New Engl.J.Med. 287 : 237, 1972.

3. Axelsson, J.:

Catecholamine functions.

Rev.Physiol. 33: 1, 1971

4. Bona, G.F. Di, Zambraski, E.J., Aguilera, A.J., and Kaloyamides, G.J.: Neurogenic control of renal tubular sodium reabsorption in the dog.

Circ.Res. 25, Suppl. 1:127, 1977.

5. Borst, J.G.J. and Borst-De Geus, A. :

Hypertension explained by Starling's theory.

Lancet $1: 677,1963$.

6. Brunjes, S.:

Catecholamine metabolism in essential hypertension.

New Engl.J.Med. $271: 120,1964$.

7. Burnstock, G., Cannon, B. and Iwayama, T.:

Sympathetic innervation of vascular smooth muscle in normal and hypertensive animals.

Circ.Res. 26, 27, Suppl. 2: 5, 1970.

8. Calvelo, M.G., Abboud, F.M., Ballard, D.R., and Abdel-Sayed, W.:

Reflex vascular responses to stimulation of chemoreceptors with nicotine and cyanide activation of adrenergic constriction in muscle and non-cholinergic dilatation in dog's paw.

Circ.Res. $27: 259,1970$.

9. Charvat, J.P., Dell, P. and Folkow, B.:

Mental factors and cardiovascular disease.

Cardiologia $44: 124,1964$.

10. Coleman, T.G., Manning, Jr. R.D and Norman, Jr., A.A.

The role of salt in experimental and human hypertension.

Am.J.Med.Sci. 264: 103, 1972.

11. Costa, E., Iversen, L.L. and Paoletti, R. (eds.):

Studies on neurotransmitters at the synaptic level. In: Advances in

Biochemical Psychopharmacology series.

Vol. 6. New York, Raven Press, 1972.

12. Cowley, Jr., A.W. LLard, J.F. and Guyton, A.C.:

Role of the baroreceptor reflex in daily control of arterial pressure and other variables in dogs.

Circ. Res. $32: 564,1973$. 
13. Davis, J.O.:

The control of renin release.

Am.J.Med. 55: 333, 1973

14. Edis, A.J. and Shepherd, J.T.

Autonomic control of the peripheral vascular system.

Arch.Intern.Med. 125:716, 1970 .

15. Falck, B., Hillarp, N.A., Thieme, G., and Torp, A. :

Fluorescence of catecholamine and related compounds condensed with formaldehyde.

J. Histochem. Cytochem. 10:348, 1962.

16. Ferrario, C.M., Gildenberg, P.L. and McCubbin, J.W.:

Cardiovascular effects of angiotensin mediated by the central nervous system.

Circ. Res. 30: 257, 1972.

17. Folkow, B., Heymans, C and Neil, E.:

Integrated aspects of cardiovascular regulation

In: The Handbook of Physiology, sec. 2, vol. III, chap. 49. American

Physiological Society, Washington, D.C., 1965, p. 1787.

18. Fonnum, $F$.:

Recent developments in biochemical investigations of cholinergic transmission.

Brain Res, $62: 497,1973$.

19. Geffen, L.B. and Livett, B.G.

Synaptic vesicels in sympathetic neurons.

Physiol Rev, 51: 98, 1971.

20. Glick, G. and Braunwald, E.

Relative roles of the sympathetic and parasympathetic nervous system in the reflex control of heart rate.

Circ.Res $16: 363,1965$.

21. Guyton, A.C.:

In: Textbook of medical physiology. W.B. Saunders Company. Philadelphia.

Fifth edition, p. 769, 1976.

22. Guyton, A.C., Coleman, T.G., Cowley, Jr., A.W., Manning, Jr, R.D., Noman, Jr. R.A., and Ferguson, J.D.:

A systems analysis approach to understanding long-range arterial blood pressure control and hypertension.

Circ. Res. 35: 159, 1974.

23. Hagen, G.H.L.: Uber die Bewegung des Wassers in engen cylindrischen Röhren.

Ann. O.Phys.U. Chem. $46: 423,1839$.

24. Hăggendal, J. :

Some aspects of the release of the adrenergic transmitter.

J.Neural.Transm. Suppl. 11: 135, 1974.

25. Hebb, C.:

CNS at cellular level: identity of transmitter agents.

Ann.Fev.Physiol. 32: 165, 1970. 
26. Hess. W.R. und Brügger, M. :

Das subkortikale Zentrum der affektiven Abwehrreaktion.

Helv.Physiol.Pharmacol. Acta $1: 33,1943$.

27. Hess, W.R. :

Das Zwischenhirn-Syndrome, Lokalizationen, Funktionen.

Benno Schwabe \& Co., Basel, 1949.

28. Hökfelt, T., Fuxe, K., Goldstein, M., and Johansson, O.:

Immunohistochemical evidence for the existence of adrenaline neurons in the rat brain.

Brain Res. $66: 235,1974$.

29. Jenkinson, D.H:

Classification and properties of peripheral adrenergic receptors

Brit.Med.Bull. $29 ; 142,1973$.

30. Karlin, A. :

The acetylcholine receptor. Progress report.

Life Sci. 14:1385, 1974.

31. Karplus, J.P. und Kreidl, A.:

Gehirn und Sympathicus. VII. Uber Bezlehungen der Hypothalamus

Zentren zu Blutdruck und innere Sekretion.

Pflügers Arch. 215:667, 1927.

32. Kezdi, P and Wennemark, J.:

Baroreceptor and sympathetic activity in experimental renal hypertension.

Circulation $17: 785,1958$.

33. Komer, P.l.:

Regional organization of autonomic nervous system.

Brain Res. $87: 339,1975$.

34. Korner. P.I., West, M.J., Shaw, J., and Lither, J.B.:

'Steady-state' properties of the baroreceptor-heart reflex in essential hypertension in man.

Clin.Exp.Pharmacol.Physiol. $1: 65,1974$.

35. Kreiger, E.M.:

Time course of baroreceptor resetting in acute hypertensian.

Am.J.Physiol. $218: 486,1970$.

36. Livingstone, R.B.:

Neural integration. In: Pathophysiology: Altered Regulatory Mechanisms in Disease, ed. E.D. Frohlich.

Lippincott, Philadelphia, 1972, p. 599.

37. Malmejac, J. :

Activity of the adrenal medulla and its regulation.

Physiol. Rev. $44: 186,1964$.

38. Masuyama, $Y$ : :

The influence of the sympathetic innervation on carotid sinus activity. Jap. Heart J. 1: 169, 1960.

39. Meelander, S. and Johansson, B.

Control of resistance, exchange and capacitance functions in the peripheral circulation.

Pharmacol.Rev. 20: 117, 1968. 
40. Molinoff, P.B., Nelson, D.L. and Orcutt, J.C.:

Dopamine-beta-hydroxylase and the regulation of the noradrenergic neuron.

Adv.Biochem.Psychophamacol. $12: 95,1974$.

41. Nickerson, M. :

Adrenergic receptors.

Circ. Pes. 32, Suppl. 1:53, 1973.

42. Ninomiya, I., Irisawa, A. and Nisimaru, N.

Nonuniformity of sympathetic activity to the skin and kidney.

Am.J.Physiol $224: 256,1973$.

43. Norberg, K.A. :

Transmitter histochemistry of the sympathetic adrenergic nervous system.

Brain Res. 5: 125, 1967

44. Onesti, G., Fernandes, M. and Kim, K.E. (Eds.):

Regulation of Blood Pressure by the Central Nervous System.

Grune \& Stratton, New York, 1976, p. 81

45. Paintal, A.S : Cardiovascular receptors. In:

Handbook of Sensory Physiology, vol. 3. Enteroceptors, pt. 1, ed. E. Neil.

Springer-Verlag. New York, 1971, p. 1.

46. Paton, D.M. (ed.):

The Mechanism of Neuronal and Extraneuronal Transport of Catecholamines.

New York, Raven Press, 1975.

47. Pohorecky, L.A. and Wurtman, R.J.:

Adrenocortical control of epinephrine synthesis.

Pharmacol.Rev, 23: 1, 1971.

48. Poiseuille, J.L.M. :

Recherches sur la force du cceur aortique: Extraits des Thèmes, soutenues dans les Trois Facultés de Médicine de France.

Arch.Gen.Med. 18:550, 1828.

49. Potter, W.P. de, Chubb, I.W. and Schaepdryver, A.F. de:

Pharmacological aspects of peripheral noradrenergic transmission.

Arch. Int. Pharmacodyn. Ther. 196. Suppl. 196: 258, 1972.

50. Aanson, S.W. and Magoun, H.W.:

The hypothalamus.

Ergeb.Physiol. 41:56, 1939.

51. Reis, D.J. and Fuxe, $K$.

Adrenergic innervation of the carotid sinus.

Am.J.Pnysiol. 215: 1054, 1968.

52. Robertis, E. E de and Schacht, J. (eds.):

Neurochemistry of Cholinergic Receptors.

New York. American Elsevier Publishing Co., Inc. 1974.

53. Sagawa, $K$. and Watamabe, $K$. :

Summation of bilateral carotid sinus signals in the barostatic reflex.

Am.J.Physiol. 209: 1298, 1965. 
54. Scher, A.M and Young, A.C.:

Servoanalysis of carotid sinus reflex effects on peripheral resistance.

Circ.Res. 12:152, 1963.

55. Selkurt, E.E.

Effect of pulse pressure and mean arterial pressure modification on renal hemodynamics and electrolyte and water excretion.

Circulation 4: 541, 1951.

56. Slick, G.L., Agullera., A.J., Zambraski, E.J. Di Bona, G.F., and Kaloyamides, G.J.:

Renal neuroadrenergic transmission.

Am. J.Physiol. 229: 60, 1975.

57. Smith, A.D. :

Cellular contral of the uptake, storage, and release of noradrenaline in sympathetic nerves.

Biochem.Soc.Sym. 36: 103, 1972.

58. Starke, K.:

Regulation of catecholamine release: alpha-receptor mediated feedback control of peripheral and central neurons.

In: Frontiers of Catecholamine Research, eds. E. Usdin and S.H. Snyder, Pergamon, New York, 1973, p. 561.

59. Struyker Boudier, H.A.J. en Rahn, K.H. :

Systeemanalyse van de bloeddrukregulatie; het sympathisch zenuwstelsel en hypertensie.

Ned.T.Geneesk. 123: 960, 1979.

60. Uvnäs, B.:

Central cardiovascular control.

In: The Handbook of Physiology, sec. 1, vol. II, chap. 40. American Physiological Society, Washington, D.C., 1960, p.1787.

61. Uvnäs, B.:

Cholinergic muscle vasodilatation.

In: Cardiovascular Regulation in Health and Disease, eds. C. Bartorelli and Zanchetti. Cardiovascular Research Institute, Milan, 1971, p. 17.

62. Weinshilboum, R.M., Nguyen, B.T., Johnson, D.G., Kopin, J.J., and Axelrod, J.:

Proportional release of norepinephrine and dopamine-beta-hydroxylase from sympathetic nerves.

Science $174: 1349,1971$.

63. Winkler, H., Schneider, F.H. Rutener, F.H., Nakane, C., and Hörtnagl, H.:

Membranes of adrenal medulla: their role in exocytosis.

Adv. Cytopharmaco $2: 127,1974$. 


\section{Hoofdstuk IV. vergelijkende onderzoeken betreffende het autonome zenuwstelsel en de bloeddrukregulatie bij borderline hypertensieve en normotensieve controle personen}

\section{- Inleiding}

Zoals beschreven werd in hoofdstuk III is de bloeddrukregulatie een zeer complex geheel, waarbij een groot aantal organen en orgaansystemen een rol speelt. Hun onderlinge samenhang wordt gewaarborgd door middel van een aantal regelsystemen. Bij een patiënt met een langer bestaande hypertensie moet de kans dat de primaire oorzaak van de dysregulatie nog te detecteren valt bijzonder gering geacht worden, immers een optredende verandering van de circulatie zal een groot aantal regelsystemen in gang zetten, waarbij de primaire oorzaak van de veranderde circulatie niet meer als zodanig te herkennen is. Met betrekking tot een studie waarin gezocht wordt naar de oorzaak van hypertensie lijkt het daarom voor de hand te liggen als studie-object proefpersonen te kiezen waarbij het hypertensief lijden nog in een beginfase verkeert. Daarom werden jonge proefpersonen met een borderline hypertensie uitgenodigd in het onderzoek fe participeren. Daar het te verwachten is dat een deel van deze borderline hypertensieven later een echte hypertensie zal ontwikkelen (Evans, 1957; Mathewson, 1957 ; Stamler et al., 1958 ; Kooperstein el al., 1962 ; Julius et al. 1964 ; Paffenbarger et al., 1968) werd het onderzoek longitudinaal opgezet, zodat het mogelijk is veranderingen in de bloeddruk te correleren aan veranderingen in de activiteit van het autonomie zenuwstelsel. Een dergelijke opzet kan tevens enig inzicht verschaffen in de vraag hoe vaak en in welk tijdsverloop er uit een borderline hypertensie een echte hypertensie ontstaat. Gezien de wens onze proefpersonen gedurende een langer aantal Jaren te vervolgen werd afgezien van bloedige bloeddrukmetingen daar immers te verwachten is dal door een dergelijke invasieve methodiek het aantal deelnemers aan de studie snel zou verminderen.

In hoofdsluk IV.1. wordt een onderzoek beschreven betreffende de activiteit van het sympathische zenuwstelsel en het renine systeem bij borderline hypertensieve en normotensieve controle personen. De effecten die het sympathische zenuwstelsel veroorzaakt, worden niet alleen bepaald door de activiteit van het sympathische zenuwstelsel maar tevens door de gevoeligheid van het organisme voor sympathische invloeden. Om hier enige duidelijkheid over te verkrijgen werd er een onderzoek verricht naar de effecten van intraveneus toegediende isoproterenol en noradrenaline. Deze infusie studies worden beschreven in deel IV.2. en IV.3. Zoals eerder beschreven in hooldstuk 111 ., beinvloedt ook het parasympathische zenuw- 
stelsel de bloeddrukregulatie en wel voornamelijk door de invloeden die dit deel van het autonome zenuwstelsel uitoefent op het hart. In deel IV.4. wordt een vergelijkend onderzoek beschreven naar de activiteit van het parasympathische zenuwstelsel bij borderline hypertensieve en normotensieve controle personen.

Van de studie betreffende het sympathische zenuwstelsel en het renine systeem zullen de eerste vervolgresultaten beschreven worden. Alle proefpersonen deelnemend aan deze studie werden tot nu toe twee jaar vervolgd, waarbij elke drie maanden de bloeddruk en harttrequentie werden gecontroleerd en waarbij bij opname in de studie en na telkens een jaar een onderzoek werd verricht naar de activiteit van het sympathische zenuwstelsel en het renine systeem.

Alle proefpersonen namen na volledig geïnformeerd te zijn op geheel vrijwillige basis deel aan de onderzoeken. De studies werden goedgekeurd door de research commissie van de Rijksuniversiteit Limburg. 


\section{Literatuur}

1. Evans, W.:

Hypertonia or uneventfull high blood pressure

Lancet II: $53,1957$.

2. Julius, S., Harburg, E., McGinn, N.F., Keyes, J., and Hoobler, S.W.:

Relation between casual blood pressure readings in Youth and at age 40. : a vetrospective study,

J. Chron. Dis. $17: 397,1964$.

3. Kooperstein, S.1., Schifrin, A., and Leahy, T.J.:

Level of initial blood pressure and subsequent development of essential hypertension. : a 10 and 15 year follow-up study.

Am. J. Cardiol. 10:416, 1962.

4. Mathewson, F.A.

Blood pressure in Canadian aviators: a fifteenth year report.

Trans. Assoc. Life uns. Med. Dir. Am. 50:53, 1957.

5. Paffenbarger Jr, R.S., Thome, M. C., and Wing, A.L.:

Chronic disease in former college students. VIII. Characteristics in youth predisposing to hypertension in later years.

Am. J. Epidemiol. 88: 25, 1968.

6. Stamler, J., Lindberg. A., Berkson, D.M., Shaffer, A., Miller, A., and Poindexter, A. :

Hypertension VIl (Proc. Coun. High Blood Press. Res.)

American Heart Association, New York, p. 23, 1958. 


\section{Hoofdstuk IV.1. Vergelijkend onderzoek naar de activiteit van het sympathische zenuwstelsel en het renine systeem bij borderline hypertensieve en normotensieve controle personen}

\section{- Inleiding en probleemstelling}

In het verleden werd er reeds veel onderzoek gedaan naar de rol van het sympathische zenuwstelsel in de genese van hypertensie. Tot 1970 was de enige beschikbare parameter de excretie van de catecholaminen en hun afbraakprodukten in de urine (De Champlain, 1977). In de laatste jaren kwamen er specifieke en gevoelige radio-enzymatische bepalingstechnieken ter beschikking waardoor het mogelijk werd de catecholaminen in het plasma te bepalen. De betekenis van het sympathische zenuwstelsel in de genese van hypertensie is nog steeds een punt van discussie. Stimulatie van de sympathische neuronen geeft aanleiding tot afgifte van noradrenaline door de zenuwuiteinden. Hoewel het allergrootste gedeelte van het vrijgekomen noradrenaline opnieuw wordt opgenomen in de sympathische neuronen, bereikt toch een kleine hoeveelheid van de neurotransmitter de circulatie. De plasma noradrenaline concentratie wordt op dit moment beschouwd als de best bruikbare index van sympathische neuronale activiteit bij de mens (Lake et al., 1976). Het allergrootste deel van het plasma adrenaline, waarschijnlijk zelfs alle plasma adrenaline, is afkomstig uit het bijniermerg. De plasma adrenaline spiegels geven daardoor een indruk van de activiteit van het bijniermerg.

Door Engelman et al. (1970), De Quattro en Chan (1972), en Louis et al. (1974) werden bij patienten met een essentiële hypertensie in rust verhoogde plasma catecholamine concentraties gevonden. Door Chadakowska et al. (1975) en Planz et al. (1976) werden er bij patiènten met een essentiële hypertensie tijdens lichamelijke activiteit verhoogde catecholamine spiegels gevonden. Andere onderzoekers, zoals Pedersen en Christensen (1975). Lake et al. (1977) en Taylor et al. (1978) vonden evenwel geen verschillen in de plasma catecholaminen van patiënten met essentiële hypertensie vergeleken met die van normotensieve controle personen tijdens rust. De keuze van de normotensieve controle personen speciaal voor wat betreft hun leeftijd en het al dan niet gewend zijn aan laboratorium onderzoeken is van grote invloed op de hoogte van hun plasma catecholamine concentraties (Jones et al. 1979). Het lijkt mogelijk dat een toegenomen sympathische activiteit slechts bij een bepaald deel van de patiënten met essentiële hypertensie aanwezig is. Afhankelijk van het al dan niet voorkomen van deze speciale groep patiënten in de hypertensieve populatie die bestudeerd wordt zal men al dan niet ver- 
hoogde catecholaminen in het plasma vinden. Daarbij lijkt het niet uitgesloten dat er juist in de periode dat een hypertensie zich pas begint te ontwikkelen, dus bij borderline hypertensieve personen, sprake is van een toegenomen sympathicus activiteit en dat er alleen in die fase van de ziekte verhoogde catacholamine concentraties in het plasma aantoonbaar zijn. Om deze hypothese te onderzoeken werd een studie gestart met het doel de plasma catecholamine concentraties van personen met een borderline hypertensie te vergelijken met die van normotensieve controle personen van gelijk gestacht en gelijke leettijd.

Het lijkt mogelijk dat verschillen in de plasma concentraties van de catecholaminen duidelijker worden tijdens lichamelijke inspanning waarbij immers een toestand bestaat van toegenomen sympathicus activiteit. De renine secretie door de nieren staat sterk onder invloed van het sympathische zenuwstelsel (Davis, 1973). Bij veranderingen in de plasma catecholamine concentraties lijkt het daardoor zeer wel mogelijk dat er tevens veranderingen optreden in de plasma renine activiteit. Daarom werden er zowel bepalingen verricht van de plasma catecholamine concentraties als van de plasma renine activiteit en concentratie; dit zowel in rust als tijdens lichamelijke inspanning. Na het eerste onderzoek bij opname in de studie. werden de proefpersonen iedere drie maanden teruggezien op het laboratorium ter controle van bloeddruk en hartfrequentie, waarna steeds na een jaar opnieuw onderzoek werd gedaan naar de activiteit van het sympathische zenuwstelsel en het renine systeem. ledere proefpersoon werd tot op heden gedurende twee jaren gevolgd. De proefpersonen, zowel de borderline hypertensieve als de controle personen, startten gelijkmatig over de tijd van een jaar verdeeld met het onderzoek. zodat een gelijkmatige verdeling over de seizoenen gegarandeerd was. Dit was wenselijk om eventueel aanwezige seizoeninvloeden zo goed mogelijk te elimineren.

\section{- Proefpersonen en methoden}

Het onderzoek werd verricht bij 50 mannelijke proefpersonen. 25 proefpersonen waren normotensief, waarbij als criterium voor een normale bloeddruk werd aangenomen een waarde van kleiner dan of gelijk aan $125 / 85 \mathrm{~mm} \mathrm{Hg}$, in staande houding. Hierbij werd de bloeddruk bij twee gelegenheden met een tussenpoos van een week bij iedere bepaling drie maal gemeten. De andere 25 proefpersonen waren borderline hypertensief, waarbij de bloeddruk als borderline hypertenslef werd beschouwd indien zi] groter dan of gelijk was aan 140/90 maar lager dan $160 / 100 \mathrm{~mm} \mathrm{Hg.} \mathrm{Ook} \mathrm{bij}$ deze proefpersonen werd de bloeddruk, in staande houding. met een tussenpoos van een week bij iedere bepaling drie maal gemeten. Alle onderzoeken werden verricht bij ambulante personen.

Om proefpersonen voor het onderzoek te krijgen vroegen we alle mannen ussen 18 en 30 jaar die een polikliniek van het Maastrichtse universiteits ziekenhuis bezochten in het onderzoek te willen participeren, tenminste indien er geen andere aandoeningen dan een lichte hypertensie aanwezig waren. Daarbij vroegen wij drie huisartsen op dezelfde wijze proefpersonen voor het onderzoek te willen winnen. Tot slot vroegen wij aan de vrijwilligers die bereid waren aan het onderzoek mee te doen, kennissen te inviteren. 
Bij iedere proefpersoon werd een volledige anamnese opgenomen alsmede een volledig lichamelijk onderzoek verricht. Van iedere proefpersoon werd de lichaamslengte en het gewicht bepaald. Van ledere deelnemer werden de volgende laboratorium parameters bepaald: bezinkingssnelheid der erytrocyten, haemoglobine gehalte, aantal erytrocyten en leukocyten, alsmede differentiële telling van de leukocyten, en de nuchtere waarden in het plasma van de bloedsuiker, natrium, kalium, creatinine, urinezuur, cholesterol en triglyceriden concentratie. Bij de proefpersonen met borderline hypertensie werden alle vormen van secundaire hypertensie uitgesloten en wel door lichamelijk onderzoek, bepaling van de plasma concentraties van creatinine en kalium, urine onderzoek op eiwit en sediment, en bepaling van de 24-uurs excretie van VMA. Daarbij werd er bil alle borderline hypertensieven een IVP gemaakt. Bij geen van de borderline hypertensieve proefpersonen waren er afwijkingen bij fundoscople. De borderline hypertensieve patiënten waten nimmer te voren met antihypertensiva behandeld

Bij opname in de studie en na éen en na twee jaar verzamelden de proefpersonen hun 24-uurs urine voor de bepaling van : natrium, creatinine, noradrenaline, adrenaline en VMA. De volgende dag werd er van ledere proefpersoon de maximale werkcapaciteit op de fietsergometer bepaald. Het ergometer onderzoek werd bij iedere proefpersoon twee maal op een Monark fietsergometer gedaan, tijdens het derde onderzoek werd gebruik gemaakt van een Lode fietsergomeler. De proefpersonen startten op de Monark fietsergometer telkens met een aanvangsbelasting van 124 Walt. De werkbelasting werd iedere 4 minuten verhoogd met 31 Watt totdat de maximale werkcapaciteit bereikt was. Bij het vervolgonderzoek na twee jaar waarbij gebruik gemaakt werd van een Lode fietsergometer werd de maximale werkcapaciteit bepaald door te starten met een belasting van 100 Watt gedurende 4 minuten. De werkbelasting wordt hierna telkens stapsgewijs verhoogd met 50 Watt in periodes van 3 minuten. Bedraagt de hartirequentie na afloop van een 3 minuten periode 150 of meer, dan wordt de werkbelasting met telkens $15 \mathrm{Watt}$ verhoogd tot de maximale werkcapaciteit wordt bereikt. De maximale werkcapaciteit werd gedefinieerd als die werkbelasting waarbij de hartfrequentie niet meer verder steeg of als die belasting waarbij de proefpersoon uitgeput raakte. Gedurende het ergometeronderzoek werd het hartritme voortdurend bewaakt op een monitor.

Tussen 5 en 14 dagen nadat de maximale werkcapaciteit op de fietsergometer was bepaald, kwamen de proefpersonen terug naar het laboratorium. In sporttenue namen zij plaats op een rustbed waarna er een naald werd aangebracht in een vena van de onderarm. Deze naald werd opengehouden met behulp van een oplossing heparine van $50 \mathrm{U} / \mathrm{ml}$. Na 30 minuten rust in liggende houding werd de hartfrequentie afgelezen uit het ECG en werd de bloeddruk gemeten. Direct hierna werd er in ijsgekoelde en gereduceerde glutathion bevattende buizen $20 \mathrm{~m}$ bloed afgenomen voor de bepaling van adrenaline en noradrenaline; tevens werd er bloed afgenomen voor de bepaling van de plasma renine activiteit en de plasma renine concentratie. Hiertoe werd $10 \mathrm{ml}$ bloed opgevangen in gekoelde polystyreen buizen waarin per $\mathrm{ml}$ bloed $1,5 \mathrm{mg} \mathrm{Na}$ - EDTA en $0,175 \mathrm{mg}$ phenantroline. 
Tevens werd de haematocriet bepaald. Onmiddellik hierna namen de proefpersonen plaats op de fietsergometer in zittende positie. Vervolgens fletsten zij gedurende 5 minuten met een werkbelasting van $50 \%$ van hun maximale capaciteit direct gevolgd door een periode van 5 minuten met een belasting van $75 \%$ van hun maximale werkcapaciteit. In de laatste 2 minuten van iedere periode werd de hartfrequentie bepaald en de bloeddruk gemeten. Daarbij werd aan het einde van de inspanningsperiode met een belasting van $75 \%$ van de maximale werkcapaciteit tevens bloed afgenomen voor de bepaling van dezelfde parameters die bepaald werden op het einde van de 30 minuten durende rustperiode.

Alle ergometer onderzoeken werden verricht tussen drie uur en vijf uur 's middags. De kamertemperatuur verschilde tijdens de beide ergometer onderzoeken van dezelfde proefpersoon nooil meer dan één graad Celsius. De proefpersonen mochten gedurende tenminste een uur voorafgaande aan de ergometer onderzoeken niet roken, daar het bekend is dat roken de catecholamine spiegels kan doen stijgen (Cryer et al., 1976).

De bloeddruk werd steeds gemeten door dezelfde onderzoeker, waarbij steeds dezelfde geijkte kwikmanometer werd gebruikt. Fase 4 van de Korotkoff tonen werd genomen als diastolische bloeddruk. De hartfrequentie werd afgelezen uit het ECG.

De plasma catecholamine concentraties werden bepaald met behulp van een radio-enzymatische methode zoals eerder beschreven door Rahn et al (1978). De extractie van de metanephrines werd evenwel gemodificeerd en verricht met behulp van ether en tetraphenylboraat, zoals dit werd beschreven door Da Prada en Zürcher (1976). Daarbij werden de metanephrinen gescheiden door middel van dunne laag chromatografie zoals beschreven door Da Prada en Zurcher (1976) in plaats van met papierchromatografie. De variatie coëfficiënt voor bepalingen op dezelfde dag is bil deze bepalingstechniek $7 \%$ zowel voor het adrenaline als voor hel noradrenaline. De variatie coëfficiënt voor bepalingen op verschillende dagen is $10 \%$ voor beide catecholaminen.

De 24-uurs urine werd verzameld in $10 \mathrm{ml} 6 \mathrm{~m} \mathrm{HCl}$ bevattende bokalen. De hoeveelheid catecholaminen in de urine werd bepaald door middel van een dubbele isotopen techniek. Hierbij werden als interne standaards aan $20 \mathrm{~m}$ urine toegevoegd: $10^{7} \mathrm{dpm}^{3} \mathrm{H}$-noradrenaline (specifieke activiteit 15 $\mathrm{Cl} / \mathrm{mmol}$, New England Nuclear, Boston, USA) en $10^{7} \mathrm{dpm}^{3} \mathrm{H}$-adrenaline (specifieke activiteit $15 \mathrm{Cl} / \mathrm{mmol}$. New England Nuclear, Boston, USA). De urine monsters werden vervolgens over een ionenwisselaar geleid zoals dat werd beschreven door Rahn (1973). Na toevoeging van gereduceerd glutathion ter verkrijging van een $6,5 \mathrm{mmol} / 1$ oplossing werd het eluaat op een $\mathrm{pH}$ van 8,2 gebracht, vervolgens werd een aliquot van $1 \mathrm{ml}$ gebruikt voor de omzetting van de catecholaminen in respectievelijk normetanephrine en metanephrine, met behulp van catechol-O-methyltransferase zoals dat beschreven werd bij de bepaling van de plasma catecholaminen. Hierbij werd evenwel ${ }^{14} \mathrm{C}$-AME (specifieke activiteit $56 \mathrm{mCl} / \mathrm{mmol}$, New England Nuclear, Boston, USA) gebruikt als methyl donor in plaats van ${ }^{3} \mathrm{H}$-methyl-S-adenosy/methionine ( ${ }^{3} \mathrm{H}$-AME). De verdere zuiveringsbewerkingen waren dezelfde als gebrukt bij de bepaling van de plasma cate- 
cholaminen. Alle bepalingen werden in duplo gedaan. Bovendien werd ieder urinemonster ook nog bepaald na toevoeging van 3 nmol noradrenaline en $3 \mathrm{nmol}$ adrenaline. De variatie coëfficiènt voor bepalingen op dezelfde dag is $5 \%$ zowel voor adrenaline als voor noradrenaline. De variatie coëfficiënt voor bepalingen op verschillende dagen is $8 \%$ voor beide catecholaminen. Voor gebruik werden ${ }^{3} \mathrm{H}$-noradrenaline en ${ }^{3} \mathrm{H}$-adrenaline gezuiverd met behulp van een ionenwisselaar zoals eerder beschreven door Rahn (1973).

De VMA excretie in de 24 uurs urine werd bepaald met een spectrofotometrische methode (Pisano et al., 1962).

De plasma renine activiteit (PRA) werd bepaald door het plasma gedurende 3 uur te incuberen bij een temperatuur van $37^{\circ} \mathrm{Celsius}$ en een $\mathrm{pH}$ van 5,5. Het ontstane angiotensine I werd geisoleerd met behulp van een ionenwisselaar (Drayer en Benraad, 1975; Lijnen et al., 1976) en vervolgens gemeten met een radioimmunoassay. De plasma renine concentratie (PRC) werd bepaald na toevoeging van plasma van genephrectomiseerde schapen (Skinner, 1967). De PRA en PRC worden vitgedrukt als ng angiotensine $1 \mathrm{uur}^{-1} \mathrm{ml}^{-1}$. Alle bepalingen werden in duplo verricht. De variatie coëfficiënt voor bepalingen op dezelfde dag is $9 \%$ en de variatie coëfficiènt voor bepalingen op verschillende dagen is $12 \%$. Deze variatie coëfficiënten gelden zowel voor PRA als voor PRC. Alle andere vermelde parameters in bloed en plasma werden bepaald in het routine laboratorium van het Maastrichtse zlekenhuis.

Alle resultaten worden weergegeven als gemiddelde waarde \pm S.E.M. De statistische significantie werd getest door middel van Student's tutest voor ongepaarde data. Indien in de tabellen 'niet significant' wordt aangegeven wordt dit gedaan door de afkorting ' $n s^{\prime}$ ' $(p>0,05)$.

\section{- Resultaten}

In de volgende paragraaf worden de resultaten van het vergelljkend onderzoek naar de activiteit van het sympathische zenuwstelsel en het renine systeem bij borderline hypertensieve en normotensieve controle personen weergegeven. Beschikbaar zijn de bevindingen bij aanvang van de studie, en de resultaten van de vervolgonderzoeken na respectievelijk éen en twee jaar.

Bij de aanvang van de studie was de gemiddelde leeftijd van de normotensieve controle groep 23,4 $\pm 0,7$ jaar, terwijl de gemiddelde leeftijd van de borderline hypertensieve patiënten $25,4 \pm 0,8$ jaar was. Het verschil is statistisch niet significant. Ook de lichaamslengte van de normotensieven en de borderline hypertensieven was niet significant verschillend, met een gemiddelde lengte van $180,4 \pm 0,1 \mathrm{~cm}$ in de normotensieve groep tegen een lengte van $176,5 \pm 1,7 \mathrm{~cm}$ in de borderline hypertensieve patiẻntengroep. Daarentegen waren de borderline hypertensieven met gemiddeld $78,2 \pm 2 \mathrm{~kg} z$ waarder dan de normotensieve controle personen met $70,1 \pm$ $1,2 \mathrm{~kg}(p<0,005)$. Deze verschillen in lichaamsgewicht werden tevens gevonden bij het controle onderzoek na één en na twee jaar. In tabel 3 worden de gegevens van leeftijd, lichaamslengte en gewicht weergegeven. 
Tabel 3

Leeftijd, lengte en lichaamsgewichten bij aanvang van de studie, en gewicht na éen en twee jaar van de normotensieven (NT) en de borderline hypertensieve proefpersonen (BHT).

\begin{tabular}{|l|r|r|c|}
\hline Parameter & NT & BHT & P \\
\hline Leeftijd (jaren) & $23,4 \pm 0,7$ & $25,4 \pm 0,8$ & ns \\
Lengte (cm) & $180,4 \pm 0,1$ & $176,5 \pm 1,7$ & ns \\
Gewicht, aanvang $(\mathrm{Kg})$ & $70,1 \pm 1,2$ & $78,2 \pm 2$ & $<0,005$ \\
Gewicht, na een jr $(\mathrm{Kg})$ & $69,8 \pm 1,1$ & $83,0 \pm 2,4$ & $<0,001$ \\
Gewicht, na twee jr $(\mathrm{Kg})$ & $69,9 \pm 1,2$ & $78,4 \pm 2,5$ & $<0,005$ \\
\hline
\end{tabular}

De data geven de gemiddelden van de groepen weer \pm S.E.M $P$ geeft de significantie van het verschil tussen de NT en de BHT.

De serumconcentraties van creatinine, natrium, kalium, urinezuur, cholesterol en de triglyceriden van beide groepen proefpersonen gevonden bij het onderzoek bij aanvang van de studie en van de vervolgonderzoeken na éen en na twee jaar worden weergegeven in de tabellen 4, 5, 6. Bij vergelijken van de waarden in de borderline hypertensieve groep met die van de normotensieve controle groep was er nimmer een significant verschil in de serumconcentraties van het creatinine, het natrium, kalium en urinezutr. Het triglyceriden gehalte was in de borderline hypertensieve groep steeds significant hoger dan in de controle groep. Het cholesterol gehalte was in de borderline hypertensieve groep groter dan in de normotensieve controle groep. Bij de onderzoeken bij aanvang van de studie en het vervolgonderzoek na één jaar was het verschil significant. Het verschil in cholesterolconcentratie bij het onderzoek na twee jaar is niet significant. 
Tabel 4

Parameters in het serum van de normotensieve (NT) en de borderline hypertensieve proefpersonen (BHT) bij aanvang van de studie.

\begin{tabular}{|l|c|c|c|}
\hline Parameter & NT & BHT & P \\
\hline Serum creatinine $(\mu \mathrm{mol} / \mathrm{l})$ & $83 \pm 2,3$ & $85 \pm 1,4$ & $\mathrm{~ns}$ \\
Serum natrium $(\mathrm{mmol} / \mathrm{l})$ & $139 \pm 0,5$ & $139 \pm 0,4$ & $\mathrm{~ns}$ \\
Serum kalium $(\mathrm{mmol} / \mathrm{l})$ & $4,3 \pm 0,1$ & $4,2 \pm 0,1$ & $\mathrm{~ns}$ \\
Serum urinezuur $(\mathrm{mmol} / \mathrm{l})$ & $0,37 \pm 0,01$ & $0,38 \pm 0,01$ & $\mathrm{~ns}$ \\
Serum cholesterol $(\mathrm{mmol} / \mathrm{l})$ & $4,41 \pm 0,18$ & $5,31 \pm 0,24$ & $<0,005$ \\
Serum triglyceriden $(\mathrm{mmol} / \mathrm{l})$ & $1,19 \pm 0,09$ & $1,74 \pm 0,22$ & $<0,05$ \\
\hline
\end{tabular}

De data geven de gemiddelden van de groepen weer \pm S.E.M.

$P$ geeft de significantie van het verschil tussen de NT en de BHT.

\section{Tabel 5}

Parameters in het serum van de normotensieve (NT) en de borderline hypertensieve proefpersonen (BHT) na één jaar.

\begin{tabular}{|l|r|r|c|}
\hline Parameter & NT & BHT & P \\
\hline Serum creatinine (umol/l) & $89 \pm 2,3$ & $87 \pm 1,7$ & ns \\
Serum natrium (mmol/l) & $140 \pm 0,4$ & $140 \pm 0,3$ & ns \\
Serum kalium (mmol/l) & $4,3 \pm 0,1$ & $4,4 \pm 0,1$ & ns \\
Serum urinezuur (mmol/l) & $0,35 \pm 0,01$ & $0,39 \pm 0,01$ & ns \\
Serum cholesterol $(\mathrm{mmol} / \mathrm{l})$ & $4,56 \pm 0,16$ & $5,39 \pm 0,26$ & $<0,01$ \\
Serum triglyceriden $(\mathrm{mmol} / \mathrm{l})$ & $0,92 \pm 0,08$ & $1,55 \pm 0,13$ & $<0,01$ \\
\hline
\end{tabular}

De data geven de gemiddelden van de groepen weer \pm S.E.M

$P$ geeft de significantie van het verschil tussen de NT en de BHT. 


\section{Tabel 6}

Parameters in het serum van de normotensieve (NT) en de borderline hypertensieve proefpersonen (BHT) na twee jaar.

\begin{tabular}{|l|c|c|c|}
\hline Parameter & NT & BHT & P \\
\hline Serum creatinine $(\mu \mathrm{mol} / \mathrm{l})$ & $89 \pm 2,3$ & $89 \pm 1,9$ & $\mathrm{~ns}$ \\
Serum natrium $(\mathrm{mmol} / \mathrm{l})$ & $141 \pm 0,3$ & $140 \pm 0,4$ & $\mathrm{~ns}$ \\
Serum kalium $(\mathrm{mmol} / \mathrm{l})$ & $4,4 \pm 0,1$ & $4,2 \pm 0,1$ & ns \\
Serum urinezuur $(\mathrm{mmol} / \mathrm{l})$ & $0,32 \pm 0,02$ & $0,34 \pm 0,02$ & $\mathrm{~ns}$ \\
Serum cholesterol $(\mathrm{mmol} / \mathrm{l})$ & $4,78 \pm 0,16$ & $5,32 \pm 0,26$ & ns \\
Serum triglyceriden $(\mathrm{mmol} / \mathrm{l})$ & $1,04 \pm 0,10$ & $1,59 \pm 0,25$ & $<0,05$ \\
\hline
\end{tabular}

De data geven de gemiddelden van de groepen weer \pm S.E.M.

$P$ geeft de significantie van het verschil tussen de NT en de BHT.

Bij aanvang van het onderzoek en bij de onderzoeken na zowel én als twee jaar waren er geen verschillen tussen de beide groepen in de excretie per 24 uur van creatinine, natrium, VMA, noradrenaline en adrenaline. De gegevens betreffende deze parameters worden weergegeven in de tabellen $7,8,9$.

\section{Tabel 7}

Parameters in de 24 uurs urine van de normotensieve (NT) en de borderline hypertensieve proefpersonen (BHT) bij aanvang van de studie.

\begin{tabular}{|c|c|c|c|}
\hline Parameter & NT & BHT & $P$ \\
\hline Creatinine 24 uurs urine $(\mathrm{g})$ & $1,89 \pm 0,06$ & $1.85 \pm 0.08$ & ns \\
\hline Natrium 24 uurs urine (mmol) & $186 \pm 11$ & $179 \pm 11$ & ns \\
\hline VMA 24 uurs urine (mg) & $2,2 \pm 0,3$ & $1,8 \pm 0,2$ & ns \\
\hline Noradrenaline 24 uurs urine (ug) & $59 \pm 5$ & $62 \pm 7$ & ns \\
\hline Adrenaline 24 uurs urine $(\mu \mathrm{g})$ & $17 \pm 2$ & $12 \pm 1$ & $\mathrm{~ns}$ \\
\hline
\end{tabular}

De data geven de gemiddelden van de groepen weer \pm S.E.M.

$P$ geeft de significantie van het verschil tussen de NT en de BHT. 


\section{Tabel 8}

Parameters in de 24 uurs urine van de normotensieve (NT) en de borderline hypertensieve proefpersonen (BHT) na eén jaar.

\begin{tabular}{|l|c|c|c|}
\hline Parameter & NT & BHT & P \\
\hline Creatinine 24 uurs urine $(g)$ & $1,74 \pm 0,04$ & $1,86 \pm 0,06$ & ns \\
Natrium 24 uurs urine (mmol) & $149 \pm 13$ & $150 \pm 13$ & ns \\
VMA 24 uurs urine (mg) & $2,7 \pm 0,2$ & $2,0 \pm 0,3$ & ns \\
Noradrenaline 24 uurs urine $(\mu \mathrm{g})$ & $47 \pm 3$ & $54 \pm 4$ & ns \\
Adrenaline 24 uurs urine $(\mu \mathrm{g})$ & $15 \pm 1$ & $13 \pm 1$ & ns \\
\hline
\end{tabular}

De data geven de gemiddelden van de groepen weer \pm S.E.M

$P$ geeft de significantie van het verschil tussen de NT en BHT.

\section{Tabel 9}

Parameters in de 24 uurs urine van de normotensieve (NT) en de borderline hypertensieve proefpersonen (BHT) na twee jaar.

\begin{tabular}{|l|l|c|c|}
\hline Parameter & NT & BHT & P \\
\hline Creatinine 24 uurs urine $(\mathrm{g})$ & $1,74 \pm 0,07$ & $1,93 \pm 0,10$ & $\mathrm{~ns}$ \\
Natrium 24 vurs urine $(\mathrm{mmol})$ & $169 \pm 12$ & $170 \pm 11$ & $\mathrm{~ns}$ \\
VMA 24 uurs urine $(\mathrm{mg})$ & $2,0 \pm 0,3$ & $2,2 \pm 0,3$ & $\mathrm{~ns}$ \\
Noradrenaline 24 uurs urine $(\mu \mathrm{g})$ & $47 \pm 5$ & $51 \pm 3$ & $\mathrm{~ns}$ \\
Adrenaline 24 uurs urine $(\mu \mathrm{g})$ & $15 \pm 2$ & $13 \pm 2$ & $\mathrm{~ns}$ \\
\hline
\end{tabular}

De data geven de gemiddelden van de groepen weer \pm S.E.M.

$P$ geeft de significantie van het verschil tussen de NT an de BHT.

De gegevens aangaande de maximale werkcapaciteit met de daarbij behorende hartfrequenties die gezien werden tijdens het ergometeronderzoek terwill de proefpersonen fietsten op maximale capaciteit, worden weergegeven in tabel 10. Zowel bij het onderzoek bij aanvang van de studie alswel bij de onderzoeken na respectievelijk éen en twee jaar was de gemiddelde maximale werkcapaciteit in de normotensieve groep groter dan van de borderline hypertensieve proefpersonen, het verschil was steeds statistisch significant. De gemiddelde hartirequenties van beide groepen tijdens maximale belasting waren niet verschillend. 
Tabel 10

Maximale werkcapaciteit (MC) en hartfrequentie (HF) bij MC van de normotensieve (NT) en borderline hypertensieve proefpersonen (BHT) bij aanvang van de studie en na respectievelijk één en twee jaar.

\begin{tabular}{|l|l|c|c|c|}
\hline Parameter & & NT & BHT & P \\
\hline Aanvang & MC (Watt) & $210 \pm 7$ & $185 \pm 5$ & $<0,005$ \\
& HF (slagen/min) & $180 \pm 3$ & $182 \pm 2$ & $n s$ \\
\hline Na één jaar & MC (Watt) & $205 \pm 4$ & $187 \pm 5$ & $<0,02$ \\
& HF (slagen/min) & $182 \pm 3$ & $184 \pm 2$ & ns \\
\hline Na twee jaar & MC (Watt) & $223 \pm 6$ & $190 \pm 8$ & $<0,005$ \\
& HF (slagen/min) & $174 \pm 3$ & $178 \pm 2$ & ns \\
\hline
\end{tabular}

De data geven de gemiddelden van de groepen weer \pm S.E.M. $P$ geeft de significantie van het verschil tussen de NT en de BHT.

De gegevens aangaande de hartfrequenties van beide groepen proetpersonen bij de onderzoeken bij aanvang van de studie en na één en na twee jaar worden weergegeven in de tabellen 11.12, 13. De borderlime hypertensieve groep bestaat na én jaar uit één proefpersoon minder en na twee jaar uit twee proefpersonen minder, dit daar deze proefpersonen hypertensief werden. Hier zal later op teruggekomen worden. Weergegeven zijn de hartfrequentie na dertig minuten liggen, na twee minuten staan, tijdens fietsen op $50 \%$ en $75 \%$ van de maximale capaciteit en tijdens inspanning op maximale werkcapaciteit. Zowel na liggen gedurende dertig minuten als na twee minuten staan zijn de hartfrequenties van de borderline hypertensieven steeds significant hoger dan die van de controle personen. Tijdens inspanning op de fietsergometer bij 50 en $75 \%$ van de maximale werkcapaciteit is de hartfrequentie van de borderline hypertensieve proefpersonen groter dan die van de normotensieve controle personen. hoewel dit verschil bij het onderzoek gedaan éen jaar na aanvang van de studie niet significant was. Dit in tegenstelling tot de onderzoeken bij aanvang van de studie en het vervolgonderzoek na twee jaar waar he? verschil in hartfequentie tijdens 50 en $75 \%$ van de maximale werkcapaciteit wel significant verschillend was. Bij alle drie de onderzoeken was er geen significant verschil in de hartfrequenties van beide groepen proelpersonen tijdens raximale inspanning

De systolische en diastolische bloeddrukwaarden worden weergegeven in de tabellen 1\%,12,13. Na dertig minuten liggen, twee minuten staan en bij inspanning. op $50 \%$ en $75 \%$ van de maximale werkcapaciteit en tijdens inspanning op maximale capaciteit zijn zowel de systolische als de diastolische bloeddruk van de borderline hypertensieve hoger dan van de normotensieve controle proefpersonen. Uitgezonderd de verschillen in de systoilsche bloeddruk bij het vervolgonderzoek na twee jaar tijdens inspanning op $75 \%$ van de maximale capaciteit en gedurende inspanning op maximale capaciteit, zijn de verschillen zowel in de systolische als diastolische bloeddruk steeds statistisch significant. 
De plasmaconcentraties van noradrenaline en adrenaline bij aanvang van de studie en na respectievelijk één en twee jaar na aanvang van de studie zowel bij rust als tijdens inspanning op de fietsergometer worden weergegeven in tabel 14. Zowel de noradrenaline concentratie als de adrenaline concentratie stegen bij beide groepen proefpersonen tijdens inspanning op een niveau van $75 \%$ van de maximale werkcapaciteit, duidelijk ten opzichte van de rustwaarden. Bij onderlinge vergelijking van de waarden bij de borderline hypertensieve met die van de normotensieve controle personen waren er bij geen van de drie onderzoeken verschillen die statistisch significant waren, dit zowel in rust als tijdens inspanning op de fietsergometer op een niveau van $75 \%$ van de maximale capaciteit.

Bij het onderzoek verricht bij aanvang van de studie en bij het vervolgonderzoek na één jaar waren er in de controle groep en in de borderline hypertensieve groep voldoende proefpersonen die dezelfde maximale capaciteit haalden zodat een onderlinge vergelijking van hun plasma catecholaminen mogelijk werd. Bij het vervolgonderzoek na twee jaar, waarbij zoals beschreven bij de methoden een iets ander protocol werd aangehouden ter bepaling van de maximale capaciteit, ontstond deze situatie niet. Bij het onderzoek bij start van de studie haalden 15 proefpersonen met een borderline hypertensie dezelfde maximale werkcapaciteit als 8 normotensieve controle personen, namelijk 186 Watt. Bij het vervolgonderzoek na één jaar haalden 13 borderline hypertensieve proefpersonen dezelfde maximale werkcapaciteit als 8 normotensieve controle personen, ook nu was dit weer 186 Watt. In tabel 15 worden de plasmawaarden van deze proefpersonen zowel in rust als bij inspanning op een niveau van $75 \%$ van de maximale werkcapaciteit dit is dus 140 Watt weergegeven. Ook nu zijn er bij onderlinge vergelijking van de waarden van de borderline hypertensieve proefpersonen met die van de normotensieve controle personen geen statistisch significante verschillen. 







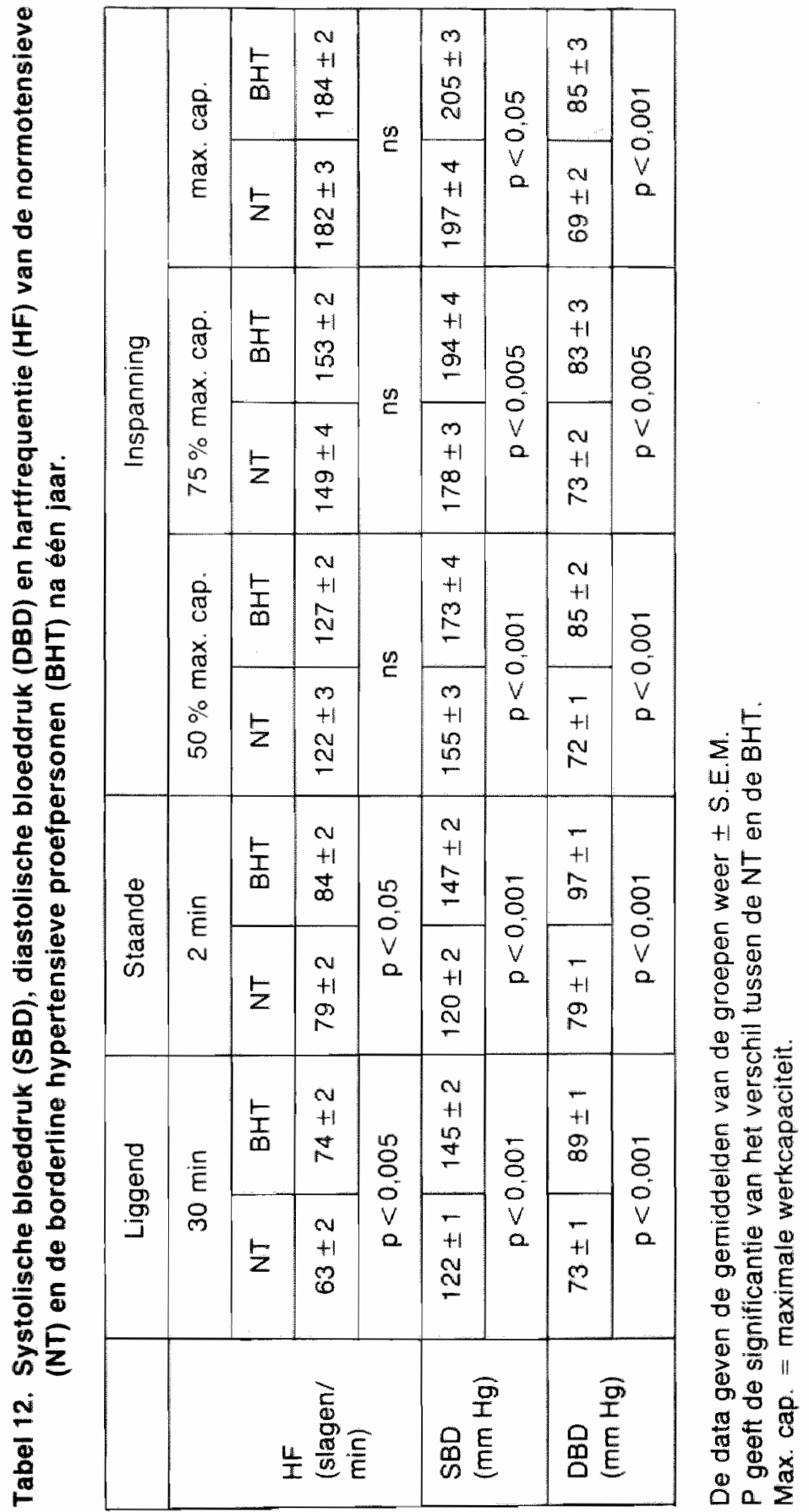




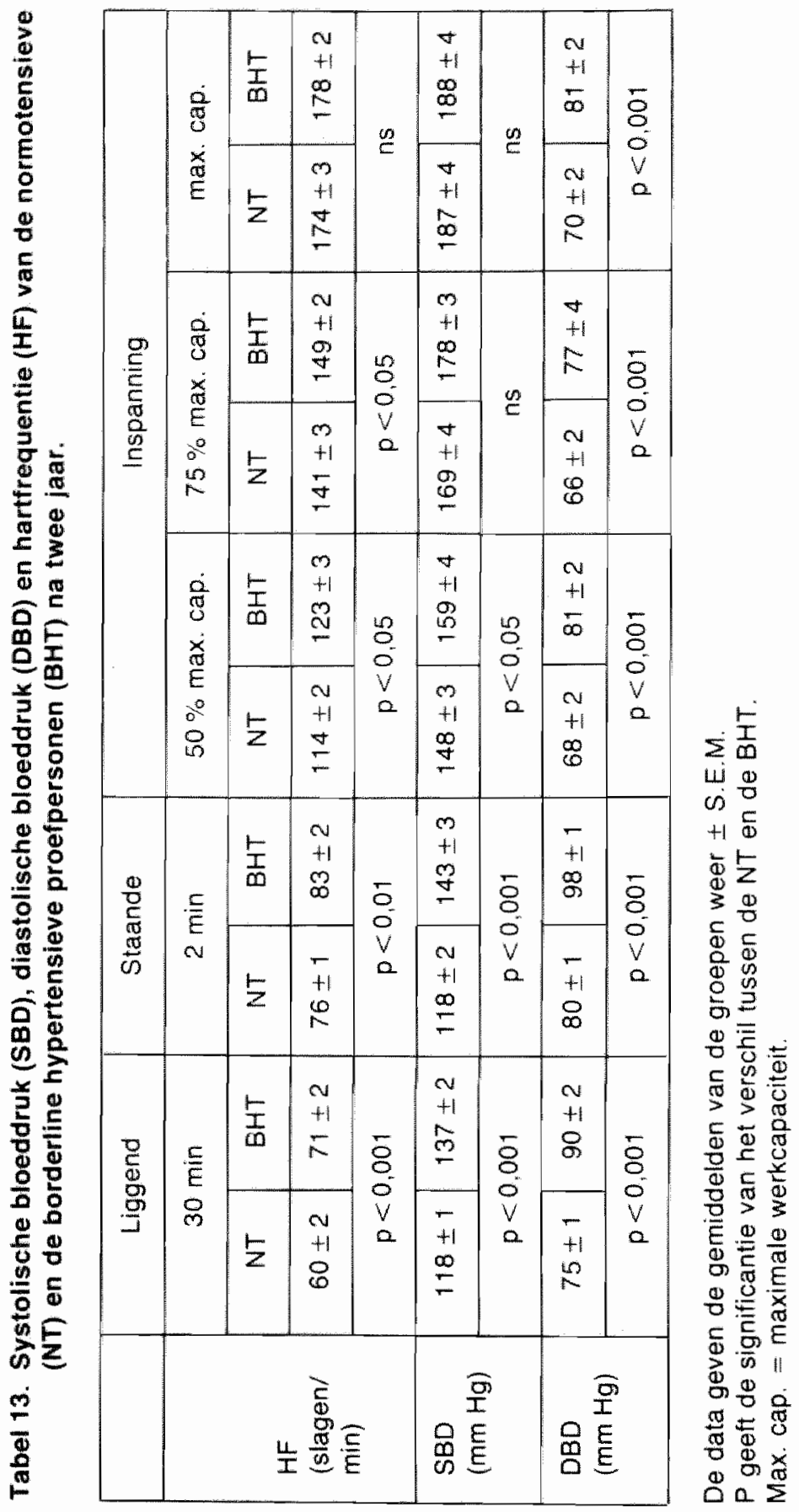


Tabel 14

Plasma concentraties in $\mathrm{ng} / \mathrm{mI}$ bij aanvang van de studie en van de onderzoeken na één en na twee jaar, van noradrenaline en adrenaline in rust (Nor $0 \%$ en Ad $0 \%$ ) en van noradrenaline en adrenaline tijdens inspanning, op een niveau van $75 \%$ van de maximale capaciteit (Nor $75 \%$ en Ad $75 \%$ ) van de normotensieve (NT) en de borderline hypertensieve proefpersonen (BHT).

\begin{tabular}{|ll|c|c|c|}
\hline Parameter & & NT & BHT & P \\
\hline Aanvang: & Nor $0 \%$ & $0,37 \pm 0,05$ & $0,41 \pm 0,05$ & $n s$ \\
& Nor $75 \%$ & $1,21 \pm 0,10$ & $1,23 \pm 0,13$ & $n s$ \\
& Ad $0 \%$ & $0,09 \pm 0,03$ & $0,07 \pm 0,02$ & ns \\
& Ad $75 \%$ & $0,21 \pm 0,04$ & $0,21 \pm 0,03$ & ns \\
\hline Na één jaar: & Nor $0 \%$ & $0,43 \pm 0,06$ & $0,37 \pm 0,05$ & ns \\
& Nor $75 \%$ & $1,18 \pm 0,14$ & $0,91 \pm 0,07$ & ns \\
& Ad $0 \%$ & $0,08 \pm 0,02$ & $0,07 \pm 0,01$ & ns \\
& Ad $75 \%$ & $0,17 \pm 0,02$ & $0,17 \pm 0,02$ & ns \\
\hline Na twee jaar: & Nor $0 \%$ & $0,24 \pm 0,03$ & $0,28 \pm 0,03$ & ns \\
& Nor $75 \%$ & $0,85 \pm 0,17$ & $0,90 \pm 0,06$ & ns \\
& Ad $0 \%$ & $0,07 \pm 0,02$ & $0,08 \pm 0,01$ & ns \\
& Ad $75 \%$ & $0,14 \pm 0,02$ & $0,16 \pm 0,03$ & ns \\
\hline
\end{tabular}

De data geven de gemiddelden van de groepen weer \pm S.E.M.

$P$ geeft de significantie van het verschil tussen de NT en de BHT 


\section{Tabel 15}

Vergelijking van de plasma concentraties in $\mathrm{ng} / \mathrm{ml}$, bij aanvang van de studíe en van het onderzoek na één jaar van noradrenaline en adrenaline in rust (Nor $0 \%$ en $\mathrm{Ad} 0 \%$ ) en van noradrenaline en adrenaline tijdens inspanning op een niveau van $75 \%$ van de maximale capaciteit (Nor $75 \%$ en Ad $75 \%$ ), van borderline hypertensieve proefpersonen (BHT) met normotensieve contrale personen (NT) die dezelfde maximale werkcapaciteit (186 Watt) haalden.

\begin{tabular}{|cl|c|c|c|}
\hline Parameter & & NT & BHT & P \\
\hline Aarvang: & Nor $0 \%$ & $0,44 \pm 0,08$ & $0,44 \pm 0,08$ & ns \\
& Nor $75 \%$ & $1,04 \pm 0,16$ & $1,17 \pm 0,16$ & ns \\
& Ad $0 \%$ & $0,11 \pm 0,05$ & $0,06 \pm 0,02$ & ns \\
& Ad $75 \%$ & $0,16 \pm 0,01$ & $0,17 \pm 0,04$ & ns \\
\hline Na én jaar: Nor $0 \%$ & $0,41 \pm 0,20$ & $0,36 \pm 0,06$ & ns \\
& Nor $75 \%$ & $1,17 \pm 0,36$ & $0,91 \pm 0,10$ & ns \\
& Ad $0 \%$ & $0,11 \pm 0,05$ & $0,07 \pm 0,01$ & ns \\
& Ad $75 \%$ & $0,12 \pm 0,01$ & $0,15 \pm 0,02$ & ns \\
\hline
\end{tabular}

De data geven de gemiddelden van de groepen weer \pm S.E.M. $P$ geeft de significantie van het verschil tussen de NT en de BHT Het aantal proefpersonen was bij aanvang : 8 NT en 15 BHT; na één jaar : 8 NT en $13 \mathrm{BHT}$.

Zowel bij het onderzoek verricht bij aanvang van de studie als bij de onderzoeken gedaan na één en na twee jaar waren de plasma renine activiteit en de plasma renine concentratie vrijwel identiek in de borderline hypertensieve groep en de normotensieve controle groep, dit zowel tijdens rust in liggende positie als tijdens inspanning op de fietsergometer op een niveau van $75 \%$ van de maximale capaciteit. De waarden van de plasma renine activiteit en plasma renine concentratie voor beide groepen worden weergegeven in tabel 16 . 


\section{Tabel 16}

Plasma renine activiteit (PRA) en plasma renine concentratie (PRC) van de normotensieve (NT) en van de borderline hypertensieve proefpersonen (BHT) gedurende rust in liggende houding en gedurende inspanning op een niveau van $75 \%$ van de maximale capaciteit. De waarden van het onderzoek bij aanvang van de studie en van de onderzoeken na één en na twee jaar worden weergegeven.

\begin{tabular}{|lll|c|c|c|}
\hline Parameter & & & NT & BHT & P \\
\hline Aanvang: & rust & PRA & $1,21 \pm 0,22$ & $0,98 \pm 0,11$ & ns \\
& & PRC & $3,88 \pm 0,65$ & $3,71 \pm 0,46$ & ns \\
& inspanning & PRA & $2,06 \pm 0,34$ & $2,02 \pm 0,30$ & ns \\
& & PRC & $5,63 \pm 0,95$ & $5,80 \pm 0,75$ & ns \\
\hline \multirow{2}{*}{ Na één jaar: } & rust & PRA & $0,95 \pm 0,15$ & $1,26 \pm 0,26$ & ns \\
& & PRC & $4,20 \pm 0,62$ & $2,79 \pm 0,45$ & ns \\
& Inspanning & PRA & $1,94 \pm 0,17$ & $2,11 \pm 0,47$ & ns \\
& & PRC & $5,58 \pm 0,49$ & $5,81 \pm 1,09$ & ns \\
\hline \multirow{2}{*}{ Na twee jaar: } & rust & PRA & $1,66 \pm 0,18$ & $1,60 \pm 0,21$ & ns \\
& & PRC & $4,08 \pm 0,41$ & $4,22 \pm 0,65$ & ns \\
& inspanning & PRA & $3,51 \pm 0,38$ & $3,47 \pm 0,42$ & ns \\
& & PRC & $7,28 \pm 0,70$ & $7,14 \pm 0,95$ & ns \\
\hline
\end{tabular}

De data geven de gemiddelden van de groepen weer \pm S.E.M PRA en PRC worden uitgedrukt als ng angiotensine $\mid \mathrm{uur}^{-1} \mathrm{~m}^{-1}$ $P$ geeft de significantie van het verschil tussen NT en BHT.

Als de plasma renine activiteit per proefpersoon, die in rust gevonden werd, werd uitgezet tegen de natrium-uitscheiding in de 24 uurs urine van diezelfde proefpersoon, waren er in het onderzoek, gedaan bij aanvang van de studie, 3 borderline hypertensieve proefpersonen met een hogere plasma renine activiteit dan de normotensieve controle personen. Deze 3 borderline hypertensieve proefpersonen met een verhoogde plasma renine activiteit in rust, hadden tevens bij inspanning. op een niveau van $75 \%$ van de maximale capaciteit, hogere plasma renine activiteit waarden dan de normotensieve controle personen tijdens inspanning.

Er waren in rust 3 borderline hypertensieve proefpersonen met een lagere plasma renine activiteit dan de normotensieve controle personen. Deze borderline hypertensieve proefpersonen hadden tevens een lagere plasma renine activiteit dan de normotensieve proefpersonen tijdens inspanning, op een niveau van $75 \%$ van de maximale capaciteit.

Bij het onderzoek na één jaar, waren er eveneens 5 borderline hypertensieve proefpersonen met een hoge en 3 borderine hypertensieve proefpersonen met een lage plasma renine activiteit.

Bij het onderzoek na twee jaar: 3 borderline hypertensieve met een hoge en 3 borderline hypertensieve met een lage plasma renine activiteit. De plasma catecholamine concentraties van de borderline hypertensieve 
proefpersonen met de hoge renine waarden zijn van dezelfde orde van grootte als de plasma catecholamine concentraties van de borderline hypertensieven met lage renine waarden. Bij geen van de drie onderzoeken waren de afwijkende renine waarden afkomstig van dezelfde proefpersonen.

Twee van de oorspronkelijke borderline hypertensieve proefpersonen werden in de loop van de studie hypertensief, hetgeen conform het protocol van de studie betekent, dat de bloeddruk in staande houding hoger was dan $160 / 100 \mathrm{~mm} \mathrm{Hg}$. Bij de tussentijdse drie maandelijkse controle-onderzoeken steeg de bloeddruk van beide proefpersonen langzaam. De belangrijkste gegevens van deze proefpersonen worden weergegeven in tabel 17. Proefpersoon 41 bereikte de hypertensieve bloeddrukwaarden één jaar na aanvang van de studie. Bij deze proefpersoon werd één jaar na aanvang van de studie nogmaals het ergometeronderzoek gedaan. De plasma catecholamine concentraties zijn bij dit tweede ergometeronderzoek niet duidelijk hoger dan bij het eerste ergometeronderzoek. Proefpersoon 48 werd hypertensiel in de loop van het tweede controle jaar. Gezien de hoogte van zijn bloeddruk werd er conform het protocol geen ergometeronderzoek meer verricht, wel werden nogmaals de catecholaminen in rust bepaald. De plasma catecholaminen van deze beide proefpersonen zijn niet hoger dan van de andere proefpersonen en vertonen in het verloop van de studie ook geen evidente stijging.

Geen van de als normotensief gestarte proefpersonen ontwikkelde in het verloop van de studie tot op heden hogere bloeddrukwaarden dan in het begin van de studie. Tot op heden werd geen van de borderline hypertensieve proefpersonen normotensief. Uitgezonderd de twee borderline hypertensieve proefpersonen die hypertensief werden bleef de bloeddruk van de proefpersonen opmerkelijk constant 
Tabel 17

Gegevens van beide borderline hypertensieve proefpersonen (resp. $\mathrm{N}^{\circ} 41, \mathrm{~N}^{\circ} 48$ ) die in de loop van de studie hypertensief werden (staande bloeddruk groter dan $160 / 100 \mathrm{~mm} \mathrm{Hg}$.). Plasma catecholaminen uitgedrukt in $\mathrm{ng} / \mathrm{ml}$. Plasma renine activiteit en concentratie uitgedrukt als $\mathrm{ng}$ angiotensine $\mid \mathrm{uur}^{-1} \mathrm{ml}^{-1}$. Zoutexcretie urine in $\mathrm{mmol}$ per 24 uur.

\begin{tabular}{|l|c|c|c|}
\hline Proefpersoon 41 & Aanvang & Na één jaar & Na twee jaar \\
\hline Nor $0 \%$ & 0,99 & 0,55 & $x$ \\
Nor $75 \%$ & 2,78 & 0,65 & $\mathrm{x}$ \\
AD $0 \%$ & 0,02 & 0,07 & $\mathrm{x}$ \\
AD $75 \%$ & 0,22 & 0,10 & $\mathrm{x}$ \\
PRA $0 \%$ & 0,53 & 0,89 & $\mathrm{x}$ \\
PRA $75 \%$ & 0,88 & 4,21 & $\mathrm{x}$ \\
PRC $0 \%$ & 1,66 & 0,21 & $\mathrm{x}$ \\
PRC 75\% & 3,08 & 3,86 & $\mathrm{x}$ \\
Natrium 24 uurs urine & 152 & 68 & $\mathrm{x}$ \\
Bloeddruk staande & $145 / 98$ & $172 / 102$ & $\mathrm{x}$ \\
Bloeddruk liggend & $140 / 95$ & $162 / 92$ & $\mathrm{x}$ \\
\hline
\end{tabular}

\begin{tabular}{|l|c|c|c|}
\hline Proetpersoon 48 & Aanvang & Na éen jaar & Na twee jaar \\
\hline Nor $0 \%$ & 0,13 & 0,20 & 0,28 \\
Nor $75 \%$ & 0,94 & 0,97 & $x$ \\
Ad $0 \%$ & 0,17 & 0,07 & 0,04 \\
Ad $75 \%$ & 0,16 & 0,17 & $x$ \\
PRA 0\% & 0,57 & 1,46 & 0,54 \\
PRA 75\% & 1,08 & 0,38 & $x$ \\
PRC 0\% & 1,58 & 1,53 & 1.99 \\
PRC 75\% & 3,41 & 4,42 & $x$ \\
Natrium 24 uurs urine & 103 & 270 & $x$ \\
Bloeddruk staande & $156 / 90$ & $158 / 96$ & $184 / 102$ \\
Bloeddruk liggend & $142 / 92$ & $158 / 92$ & $180 / 104$ \\
\hline
\end{tabular}

$\times$ Geeft aan dat de desbetreffende parameter niet verkregen werd. 


\section{- Discussie}

In deze studie waarin borderline hypertensieve personen werden vergeleken met normotensieve controle personen, werden er noch in rust noch tijdens lichamelijke inspanning op de fietsergometer verschillen gevonden tussen beide groepen in de plasma concentraties van noradrenaline en adrenaline. Ook waren er geen verschillen aantoonbaar in de plasma renine activiteit en de plasma renine concentratie van beide groepen. De excretie in de 24 uurs urine van noradrenaline, adrenaline en VMA liet geen verschil Iussen beide groepen zien. Deze bevindingen werden zowel gedaan bij hel aanvangsonderzoek als bij de vervolgonderzoeken na respectievelijk én en twee jaar.

Esler et al. (1977) bestudeerden een groep patienten met milde hypertensie. De bloeddrukwaarden van de door deze onderzoekers bestudeerde patiënten lagen tussen $150 / 90$ en $175 / 105 \mathrm{mmHg}$, en waten daardoor iets hoger dan de bloeddrukwaarden van de door ons bestudeerde borderline hypertensieve personen hoewel het verschil niet erg groot is. Patienten in de studie van Esler et al. (1977) met een hoge plasma renine activiteit werden gekenmerkt door hogere plasma noradrenaline waarden dan de normotensieve controle personen en de overige hypertensieve personen zonder een hoge plasma renine activiteit. De plasma noradrenaline concentraties van de hypertensieve proefpersonen met een normale plasma renine activiteit waren gelik aan die van de normotensieve controle personen. De patiënten met hoge plasma renine activiteit buiten beschouwing latend, kan gezegd worden dat onze bevindingen in overeenstemming zijn met die van Esler et al. (1977). In onze studie was het aantal borderline hypertensieve proefpersonen met een hoge plasma renine activiteit klein, zodat het niet mogelik was conclusies te trekken aangaande hun plasma noradrenaline concentratie. Miura et al.(1978) vonden toegenomen plasma noradrenaline concentraties bij patiënten die in de beginfase verkeerden van een hypertensief lijden. De patienten die in deze studie bestudeerd werden hadden diastolische bloeddrukken die soms hoger en soms lager waren dan $90 \mathrm{mmHg}$. waardoor zij beter beschreven zouden kunnen worden met het in dit verband vaker gebruikte begrip 'labiele hypertensie'. Het lijkt zeer wel mogelijk dat dergelijke patienten in situaties gepaard gaande met stress, zoals bijvoorbeeld een onderzoek op een laboratorium, reageren met een grotere dan normaal optredende afgifte van catecholaminen aan de circulatie. Hetzelfde zou kunnen gelden voor de patienten met een labiele hypertensie die onderzocht werden door Cousineau et al.(1978). Deze onderzoekers vonden bij hun patiënten toegenomen plasma concentraties van zowel noradrenaline als adrenaline.

Robertson et al.(1979) vonden geen verschil in de plasma noradrenaline splegel van botderline hypertensieve en normotensieve controle personen in rust. Borderline hypertensie werd in deze studie aangenomen als de bloeddruk bif twee gelegenheden, zonder stress, hoger was dan $150 / 95 \mathrm{~mm} \mathrm{Hg}$, en bij een andere gelegenheid normaal was. Personen met een bloeddruk lager dan $140 / 90 \mathrm{~mm} \mathrm{Hg}$ werden beschouwd als normotensiet. Tijdens lichamelike activiteit en gedurende zoutdepletie hadden de 
borderline hypertensieve personen hogere noradrenaline plasma con. centraties dan de normotensieve controle personen in dezelfde situatie. De conclusies die Robertson et al.(1979) uit hun studie trokken, zijn gebaseerd op een tamelijk klein aantal proefpersonen te weten 7 nomotensieven en 9 borderline hypertensieven. De plasma noradrenaline concentraties van de door hun bestudeerde groepen overlappen elkaar en de vraag rijsl of het verschil in de plasma noradrenaline concentratie zowel tijdens lichamelijke inspanning als tijdens de situatie van zoutdepletie nog wel significant zou zijn geweest als de groepen groter waren geweest. Daarbij dient nog opgemerkt te worden dat er bij de lichamelijke belasting die in dit onderzoek verricht werd door de proefpersonen te laten lopen op een tredmolen, de grootte van de belasting voor ledere proefpersoon even groot was, dus niet gecorreleerd werd aan de maximale werkcapaciteit van de afzonderlijke proefpersonen. Het lijkt dus zeer wel mogelijk dat verschillen in de conditie van de proefpersonen kan hebben bijgedragen aan de door de onderzoekers gevonden verschillen in de noradrenaline concentratie tijdens lichamelike inspanning. Daarenboven, tijdens het deel van het onderzoek waarin de proefpersonen onderzocht werden tijdens zoutdepletie, daalde de bloeddruk van de borderline hypertensieve meer dan die van de normotensieve controle personen. Hoewel het verschil in daling van de bloeddruk niet significant was, lijkt het mogelijk dat de lets grotere daling van de bloeddruk in de borderline hypertensieve groep een sterkere sympathicusstimulatie opriep dan in de controle groep. Dit zou aanleiding kunnen geven tot een hogere plasma noradrenaline concentratie tjidens zoutdepletie in de borderline hypertensieve groep.

Weidmann el al. (1979) vergeleken de plasma noradrenaline concentra* lies van borderline hypertensieve patienten met die van normotensieve controle personen. De bloeddrukwaarden van deze borderline hypertensieven waren slechts lets hoger dan die van de door ons bestudeerde hypertensieve proefpersonen. Deze onderzoekers vonden geen verschil in de plasma noradrenaline concentratie in staande positie bij vergelijking van beide groepen

De plasma catecholamine concentraties die in onze studie werden gevonden in de normotensieve groep tijdens rust in liggende positie zijn goed vergelijkbaar met de waarden die door andere onderzoekers, welke gebruk maakten van een radiometrische bepalingsmethode, werden gevonden (Pedersen en Christensen, 1975; Lake et al., 1977; Sever et al.. 1977: Taylor el al. 1978). Lagere plasma concentraties voor noradrenaline in rust bij normotensieven werden gevonden door Engelman en Portnoy (1970), de Quattro en Chan (1972), Louis el al. (1974) en Esler et al. (1977). Dat deze laatstgenoemde onderzoekers lagere noradrenaline concentraties vonden dan de eerder vermelde onderzoekers wordt waarschijnlijk veroorzaakt door de keuze van hun normotensieve controle personen. Door Engelman en Portnoy (1970) en door De Quattro en Chan (1972) werden zlekenhuispersoneel en laboratoriummedewerkers gebruikt als normoten. sieve controle personen. In de studies van Louis et al. (1974) en van Esler et al. (1977) functioneerden normotensieve patienten die gedurende langere tijd in de rustige atmosfeer van een ziekenhuis waren opgenomen als 
normotensieve controte personen. Onze veronderstelling wordt bevestigo door de bevindingen van Jones el al. (1979), die aantoonden dat de plasma noradrenaline concentraties lager zijn bij mensen die vertrouwd zijn met laboratoriumonderzoeken dan bij mensen die dit niet zijn.

De plasma catecholaminen die door ons gevonden werden tijdens lichamelijke inspanning zijn goed vergelijkbaar met de catecholamine waarden die door andere onderzoekers in vergelijkbare omstandigheden werden gevonden (Rahn et al., 1978; Christensen et al., 1979).

De waarden voor de plasma renine activiteit en plasma renine concentratie die in onze studie in de normotensieve groep in rust en tijdens inspanning werden gevonden zijn goed in overeenstemming met de waarden die door andere onderzoekers bij personen met een vergelijkbare zoutopname werden gevonden (Kotchen et al., 1971; Brunner et al., 1972 ; Costill et al., 1976; Kosunen en Pakarinen, 1976). Zoals in de studies van Werning et al. (1972) en Robertson ef al. (1979) vonden wij geen verschillen in de plasma renine activiteit tussen nomotensieve en borderline hypertensieve proefpersonen tijdens rust in liggende houding. Daarbij werden er in onze studie geen verschillen gevonden tussen de borderline hypertensieve proefpersonen en de normotensieve personen in de plasma renine concentratie in rust in liggende positie, en eveneens geen verschillen in de plasma renine activiteit en plasma renine concentratie gedurende lichamelijke inspanning. In de literatuur worden tegenstrijdge bevindingen vermeld aangaande de plasma renine activiteit bij borderline hypertensieve patiënten tijdens orthostase. Werning el al. (1972) vonden bij borderline hypertensieve proefpersonen gedurende actleve orthostase hogere waarden voor de renine activiteit dan bij normotensieven. Deze bevinding werd niet bevestigd door Robertson et al. (1979) die geen verschil vonden in renine activiteit gedurende actieve orthostase bij vergelijking van borderline hypertensieve met normotensieve controle personen. Een mogelijke verklaring voor deze verschillende bevindingen zou kunnen zijn dat in de studie van Werning et al. (1972) de gemeten plasma renine activteit niet werd gecorreleerd aan de zoutexcretie van de proefpersonen, zodat verschillen in de zoutbalans zeer wel aanleiding zouden kunnen geven to het door deze onderzoekers gevonden verschil tussen borderline hypertensieve en normotensleve controle personen. Robertson et al. (1979) bestudeerden hun proefpersonen onder streng gecontroleerde omstandigheden waarbij alle proefpersonen eenzelfe constante zoutopname hadden. Opgemerkt dient te worden dat in de studie van Robertson et al. (1979). waarbij tevens de plasma renine activiteit van beide groepen proefpersonen bepaald werd in een situatie dat de proefpersonen in een toestand van zouldepletie waren gebracht, gevonden werd dat in deze situatie de plasma renine activiteit van de normotensieve controle personen lager was dan die van de borderline hypertensieve personen. Zoals eerder besproken werd, kan dit verschil verklaard worden doordat de bloeddruk van de borderline hypertensieve personen tijdens zoutdepletie meer daalde dan die van de normotensieve controle personen.

Twee van de oorspronkelijk borderline hypertensieve proefpersonen 
werden tijdens de vervolgstudie hypertensief. Hun plasma catecholamine spiegels bij aanvang van de studie en gedurende de vervolgonderzoeken zijn niet duidelijk verschillend van die van de andere proefpersonen. Daar er in dit onderzoek geen verschil werd gevonden in de plasma catecholamine concentratie van borderline hypertensieve ten opzichte van normatensieve controle personen en de twee borderline hypertensieve proefpersonen die later hypertensief werden plasma catecholaminewaarden hebben die vergelijkbaar zijn met die van de andere proefpersonen lijkt het niet waarschijnlijk dat een toegenomen activiteit van het sympathische zenuwstelsel een belangrijke rol speett in de genese van essentiële hypertensie.

Bijzonder interessant lijkt ons de bevinding dat de hartfrequentie van de borderline hypertensieven in rust zowel in liggende houding als in staande positie hoger is dan die van de normotensieve controle personen. Deze hogere hartfrequentie van borderine hypertensieve patiënten ten opzichte van normotensieven in rust werd door verschillende onderzoekers gevonden (Julius en Schork 1971). In onze studie was de hartfrequentie van de borderline hypertensieve proefpersonen ook tijdens inspanning op de fietsergometer op een niveau van 50 en $75 \%$ van de maximale capaciteit hoger dan die bij de normotensieve controle personen. Dif verschil was weliswaar niet significant in de vervolgstudie na éen jaar, maar wel was het significant bij het aanvangsonderzoek en het vervolgonderzoek na twee jaar. De borderline hypertensieve proefpersonen worden dus onder meer gekenmerkt door een hogere hartfrequentie dan normotensieve personen hoewel hun plasma catecholaminen niet hoger zijn dan van de normotensieve personen. Drie mogelijkheden ter verklaring van dit fenomeen komen in aanmerking. Ten eerste lijkt het mogelijk dat de sympathicusactiviteit ter plaatse van bepaalde organen, zoals bijvoorbeeld het hart, verhoogd is. Een dergelijk lokaal verschil in sympathische activiteit behoeft niet weerspiegeld te worden in hel veneuze mengplasma. Deze mogelijkheid kunnen we op dit moment niet uitsluiten. Een tweede mogelijkheid ter verklaring van dit fenomeen zou erin gevonden kunnen worden dat de bèta-receptoren ter plaatse van het hart bij mensen met een borderine hypertensie gevoeliger zijn voor stimulering door de circulerende catecholaminen dan bij normotensieve personen. In hoofdstuk IV. 2 wordt ons onderzoek beschreven aangaande de gevoeligheid van cardiale receptoren bij borderline hypertensieve en normotensieve controle personen. De resultaten van hel aldaar beschreven onderzoek ondersteunen de hypothese dat de cardiale beta-receptoren van mensen met een borderline hypertensie sterker op de circulerende catecholaminen reageren niet. Een derde mogelijkheid om de hogere hartfrequentie van borderline hypertensieven te verklaren terwijl de plasma catecholaminen van gelijke hoogte zin wordt gevonden in de hypothese dat de parasympathische activiteit bij mensen met een borderline hypertensie lager is dan bij normotensleven Een afname van de activiteit van de nervus vagus heeft immers een versnelling van de hartactie lot gevolg. Deze hypothese wordt ondersteund door onze bevinding dat bij elk van de drie onderzoeken de hartfrequenties van beide groepen proefpersonen tijdens inspanning op maximale werkcapaciteit niet meer verschillen. Tijdens maximale inspanning is de invloed 
van het parasympathische zenuwstelsel op het hart niet meer van betekenis zoals aangetoond werd in het onderzoek van Robinson (1966). In ons onderzoek naar de activiteil van het parasympathische zenuwstelsel, dat beschreven wordt in hoofdstuk IV. 4 worden inderdaad argumenten gevonden voor de hypothese dat het parasympathische zenuwstelsel bij mensen met een borderline hypertensie minder actiet is dan bij normotensieven. Ook wit het onderzoek verricht door Julius et al. (1971) bleek dat een verschil in parasympathische activiteit een belangrijke rol speelt bij het tot stand komen van de hogere hartfrequentie bij borderline hypertensieven. In deze studie bestudeerden Julius et al. (1971) borderline hypertensieve personen met een hartminuutvolume per $m^{2}$ lichaamsoppervlak van meer dan 3,6 $/ \mathrm{min}$. De hartfrequentie in rust van deze borderline hypertensieven was groter dan die van een groep normotensieven. Hoewel een intraveneuze injectie van $0.2 \mathrm{mg} / \mathrm{kg}$ propranolol een sterkere daling van de hartrequentie veroorzaakte in de borderline hypertensieve groep dan in de normotensieve groep bleef de hartfrequentie van de borderline hypertensieve hoger dan die van de normotensieve groep. Pas na toediening van een grote dosis atropine verdween het verschil in hartfrequentie.

Het vergelijkende onderzoek aangaande de activiteit van het parasympathische zenuwstelsel bij borderline hypertensieve en normotensieve proefpersonen zal later in hoofdstuk IV.4 beschreven worden. In het volgende hoofdstuk zal allereers thet onderzoek beschreven worden waarin de gevoeligheid van de cardiale bèta-receptoren bij borderline hypertensieve en normotensieve controle personen met elkaar worden vergeleken. 


\section{Literatuur}

1. Brunner, H.R., Laragh, J.H., Baer, L., Newton, M.A., Goodwin, F.T., Krakotf, L.R., Bard, R.H., and Bühler, F.R.:

Essential hypertensiom : renin and aldosterone, heart attack and stroke. New Engl. J. Med. 286: 441, 1972

2. Chodakowska, J., Nazar, K., Wocial, B., Jarecki, M., and Skórka, B.: Plasma catecholamines and renin activity in response to exercise in patients with essential hypertension.

Clin. Sci. Mol. Med. 49:511, 1975.

3. Christensen, N.J., Galbo, H., Hansen, J.F., Hesse, B., Richter, E.A. and Trapjensen, $\mathrm{J}$ : :

Catecholamines and exercise.

Diabetes. 28 : Suppl. 1,58, 1979.

4. Costill, D.L., Branam, G., Fink, W., and Nelson, R.

Exercise induced sodium conservation: changes in plasma renin and aldosterone.

Med. Sci. in Sports. 8: 209, 1976.

5. Cousineau, D., de Champlain, J., and Lapointe, L. :

Circulating catecholamines and systolic time intervals in labile and sustained hypertension.

Clin. Sci. Mol. Med. 55: 65, 1978.

6. Creyer, P.E., Haymond, M.W., Santiago, J.V., and Shah, S.D.:

Smoking associated catecholamine release and adrenergic events.

New Engl. J. Med. 295: 573, 1976.

7. Davis, J.O.:

The control of renin release.

Am. J. Med. 55: 333, 1973.

8. De Champlain, J.:

The sympathetic system in hypertension.

In Clinics in Endocrinology and Metabolism, 6. pp 643-644. 1977. Ed. Landsberg, L. Saunders, Philadelphia.

9. Drayer, R.M., and Benraad, T.J.:

The reliability of the measurement of plasma renin activity by radioimmunoassay.

Clinica Chimica Acta. $61: 309,1975$.

10. Engelman, $K$., and Portnoy, B.:

A sensitive double-isotope derivative assay for norepinephrine and epinephrine: normal resting human plasma levels.

Circ. Res. 26: 53, 1970.

11. Engelman, K., Portnoy, B., and Sjoerdsma, A. :

Plasma catecholamine concentrations in patients with essential hypertension.

Circ. Res. 27, Suppl. 1, 141, 1970. 
12. Ester, M., Julius, S. Zweifler, A., Randall, O., Harburg, E., Gardiner, H. and De Quattro, $V$ :

Mild high-renin essential hypertension: neurogenic human hypertension?

New Engl. J. Med. 296: 405, 1977

13. Jones, D.H. Hamilton, C.A., and Reid, J.L.

Choice of control groups in the appraisal of sympathetic nervous activity in essential hypertension.

Clin. Sci. $57: 339,1979$

14. Julius, S., Pascual, A.V., and London, R.:

Role of parasympathetic inhibition in the hyperkinetic type of borderline hypertension.

Circulation. 44 : 413. 1971.

15. Julius, $\mathrm{S}$. and Schork, A.

Borderline hypertension - a critical review.

J. Chron. Dis. 23; 723, 1971.

16. Kosunen, K.J. and Pakarinen, A.J.:

Plasma renin, angiotensin 11 , and plasma and urinary aldosterone in running exercise.

J. Appl. Physiol. $41: 26,1976$

17. Kotchen, T.A., Hartley. L.H., Mougey, E.H., Jones, L.G., and Mason. J.W.:

Renin, norepinephrine, and epinephrine responses to graded exercise. J. Appl. Physiol. 31, 178, 1971.

18. Lake, C.R., Ziegler, M.G., and Kopin, I.J.:

Use of plasma norepinephrine for evaluation of sympathetic neuronal function in man.

Life Sci. 18: 1315, 1976.

19. Lake, C.R., Ziegler, M.G., Coleman, M.D., and Kopin, I.J. :

Age-adjusted plasma norepinephrine levels are similar in normotensive and hypertensive subjects.

New Engl. J. Med. 296: 208, 1977

20. Lijnen, P.J., Amery, A.K.P.C., and Fagard, R.H.:

Comparison between a biological and a radioimmunological assay of plasma renin concentration.

Federation of European Biochemical Societies Letters 61: 32, 1976.

21. Louis, W.J., Doyle, A.E., Anavekar. S.N., Johnston, C.l., Geffen, L.B., and Rush, R. :

Plasma catecholamine, dopamine-beta-hydroxylase, and renin levels in essential hypertension.

Circ. Res. 34 : Suppl. I, 57, 1974.

22. Miura, Y., Kobayashi, K., Tomioka, M., Adachi, M, and Yoshinaga, K.:

Plasma noradrenaline concentrations and haemodynamics in the early stage of essential hypertension.

Clin. Sci. Mol. Med. 55: 69, 1978.

23. Pedersen, E.B., and Christensen, N.J.

Catecholamines in plasma and urine in patients with essential hypertension determined by double - isotope derivate techniques.

Acta med. Scand. $198: 373,1975$. 
24. Pisano, J.J., Crout, J.R., and Abraham, D.:

Determination of 3-methoxy-4-hydroxy mandelic acid in urine.

Clin. Chim. Acla 7:285, 1962.

25. Planz, G., Gierlichs, H.W., Hawlina, A., Planz, R., Stephany, W., and Rahn, K.H. :

A comparison of catecholamine concentrations and dopamine - betahydroxylase activities in plasma from normotensive subjects and from patients with essential hypertension at rest and during exercise.

Klin. Wschr. $54: 561,1976$.

26. Da Prada, M., and Zürcher, G. :

Simultaneous radioenzymatic determination of plasma and tissue adrenaline, noradrenaline and dopamine within the femtomole range.

Life Sci. 19:1161, 1976.

27. De Quattro, $V$, and Chan, S. :

Raised plasma catecholamines in some patients with primary hypertension.

Lancet I: 806, 1972.

28. Rahn, K.H.:

Untersuchungen über den Einfluss von Guanethidin (Ismelin ${ }^{\text {A) }}$ auf die Katecholaminausscheidung im Harn von Hypertonikern.

Klin. Wschr. $51: 431,1973$.

29. Rahn, K.H., Gierlichs, H.W., Planz, G., Planz, R., Schols, M., and Stephany, W. :

Effect of propranolol on plasma catecholamines in hypertensive patients. Eur. J. Clin. Invest. 8: 143, 1978.

30. Robertson, D., Shand, D.G., Hollifield, J.W., Nies, A.S., Frölich, J.C., and Oates, d. :

Alterations in the responses of the sympapthetic nervous system and renin in borderline hypertension.

Hypertension 1: 118, 1979.

31. Robinson, B.F., Epstein, S.E., Beiser, G.D., Braunwald, E.:

Control of heart rate by the autonomic nervous system: Studies in man on the interrelation between baroreceptor mechanisms and exercise

Circ. Res. 19:400, 1966.

32. Sever, P.S., Birch, M., Osikowska, B., and Tumbridge, R.D.G.

Plasma noradrenaline in essential hypertension.

Lancet I: $1078,1977$.

33. Skinner, S.L.:

Improved assay methods for renin 'concentration' and 'activity' in human plasma.

Circ Res. 20:391, 1967.

34. Taylor, A.A., Pool, J.L., Lake, C.R., Ziegler, M.G., Rosen. R.A., Rollins, D.E., and Mitchell, J.R.:

Plasma norepinephrine concentrations - no differences among normal volunteers and low, high or normal renin hypertensive patients.

Life Sci. 22 : 1499, 1978. 
35. Weidmann, P., Keusch, G. Flanner, J., Ziegler, W.H., and Reubi, R.C.: Increased ratio between changes in blood pressure and plasma norepinephrine in essential hypertension.

J. Clin. Endocrino: Metab. 48:727, 1979

36. Werning, C. Fischer, M., Kaip, E. Stiel, D., Trübstein, G.K., und Vetter, H. Erhöhte Reninstimulation nach Orthostase bel labiler oder Grenzwerthypertonie.

Disch. Med. Wschr. 97: 1038, 1972. 


\title{
Hoofdstuk IV.2
}

\author{
Vergelijkend onderzoek naar \\ de verandering in \\ hartfrequentie tijdens \\ intraveneuze toediening van \\ isoproterenol bij borderline \\ hypertensieve en \\ normotensieve controle \\ personen
}

\section{- Inleiding en probleemstelling}

Verschillende onderzoekers vinden bij borderline hypertensieve patienten in rust een gemiddeld hogere hartfrequentie dan bij normotensieve controle personen van gelijke leeftijd (Sannerstedt, 1966 ; Lund-Johansen, 1967 ; Julius en Conway, 1968 ; Julius et at., 1974). Ook in onze studie werd bij borderline hypertensieve proefpersonen een hogere hartfrequentie in rust gezien dan bij normotensieve controle personen (zie hoofdstuk IV.1). De snellere hartactie zou op drie manieren kunnen ontstaan. Ten eerste kan de intrinsieke pacemaker van het hart te snel functioneren. Ten tweede bestaat de mogelijkheid dat het effect van het autonome zenuwstelsel op het hartritme dusdanig veranderd is, vergeleken met de situatie die bestaat bi) normotensieven, dat een toegenomen hartfrequentie het resultaat is. Ten derde lijkt het mogelijk dat de cardiale bèta-receptoren in versterkte mate gevoelig zijn voor de invloeden uitgeoefend door het sympathische zenuwstelsel of dat er een verminderde cardiale gevoeligheid voor acetyl choline tot stand is gekomen. Achtereenvolgens zullen we deze drie mogelijkheden bespreken waarna een probleemstelling aangaande de derde mogelijkheid geformuleerd wordt.

Wat betreft de eerste mogelijkheid kan gesteld worden, dat het door het werk van Julius et al. (1971) waarschijnlijk is geworden dat het hartritme van mensen met een borderline hypertensie, in de situatie dat het hart geen invloeden meer ondervind vanuit het autonome zenuwstelsel, gelik is aan dat van normotensieve proefpersonen in dezelfde situatie. Met andere woorden: indien de invloeden van zowel hel parasympathische als het sympathische zenuwstelsel op het hart geblokkeerd zijn, zijn de hartfrequenties van borderline hypertensieve en normotensieve controle personen gelijk. De intrinsieke pacemaker functioneert met een gelijke trequentie. In deze studie werden de invioeden van het autonome zenuwstelsel op het hart geblokkeerd met propranolol $(0.2 \mathrm{mg} / \mathrm{kg} \mathrm{i.v.)}$ en atropine sulfaat $(0,04 \mathrm{mg} / \mathrm{kg} \mathrm{i.v.)}$.

Wat betreft de tweede mogelijkheid: een snellere hartactie kan ontstaan, zowel door een toegenomen effect van de sympathicus op het hart als door een afname van de parasympathische activiteit. Wat betreft de activiteit van 
het sympathische zenuwstelsel bij mensen met een borderline hypertensie verwijzen we hier naar hoofdstuk IV. van dit proefschrift. In onze studie werden geen aanwijzingen gevonden dat er bij borderline hypertensieve patienten inderdaad sprake is van een toegenomen sympathische activiteit. De mogelijkheid bestaat echter nog steeds dat er ter plaatse van de receptoren van het adrenerge systeem bij mensen met een borderline hypertensie, toch sprake is van veranderde catecholaminen concentraties vergeleken mel normotensieven. Deze mogelijkheid kunnen we momenteel niet uitsluiten. Het parasympathische zenuwstelsel, en wel een afname van haar activiteit, zou zeer wel de toegenomen hartfrequentie bij borderline hypertensieve personen kunnen veroorzaken. Ons onderzoek naar de activiteit van het parasympathische zenuwstelsel bij patienten mel een borderline hypertensie wordt beschreven in hoofdstuk IV.4.

Als derde verklaring voor de hogere hartfrequentie van patiënten met een borderline hypertensie ten opzichte van normotensieve mensen lijkt de mogelijkheid te bestaan dat borderline hypertensieve personen onder meer gekenmerkt worden door een toegenomen gevoeligheid van hun cardiale receptoren voor sympathische invioeden of anderzijds een verminderde cardiale gevoeligheid voor acetylcholine. Deze laatste rrogelikheid kunnen we momenteel niel uitsluiten. Bij een toegenomen gevoeligheid voor sympathische invloeden lijkt het mogelijk dat er ondanks een normale sympathicustonus een hogere hartfrequentie tot stand komt. Om deze mogelijkheid te onderzoeken maakten wij bij een aantal proefpersonen zowel uit de borderline hypertensieve populatie als uit de normotensieve groep dosis-werkingscurves van het chronotrope effect van isoproterenol.

\section{- Proefpersonen en methoden}

Uit de ter beschikking staande proefpersonen populaties nodigden wij 16 personen uit om aan dit deel van het onderzoek te willen participeren. $\mathrm{Zij}$ werden allen volledig over de aard van het onderzoek geinformeerd. De 8 normotensieve proefpersonen en de 8 borderline hypertensieve patienten beantwoordden aan de criteria zoals gesteld voor het onderzoek aangaande de activiteit van het sympathische zenuwstelsel en het renine systeem zoals beschreven in hoofdstuk IV.1. Van iedere proefpersoon werden bif gelegenheid van de isoproterenol infusie de volgende parameters verkregen: leeftijd, gewicht, bloeddruk na 2 minuten staan en bloeddruk en hartrequentie na 20 minuten liggen. De bloeddruk werd gemeten met de kwikmanometer aan de rechterarm door steeds dezelfde onderzoeker. Nadat er een naald was ingebracht in éen van de venen van de linker onderarm en de proefpersonen waren aangesloten aan het ECG toestel, rustten zij gedurende 30 minuten in liggende houding in een rustige omgeving waarbij er door de onderzoekers zo weinig mogelijk werd gesproken. Vervolgens werd onder voortdurende registratie van het ECG isoproterenol intraveneus toegediend mel behulp van een infusiepomp waarbij de infusiesnelheid stapsgewijze werd verhoogd. Bij ledere stap werd het infuus zolang gegeven tot de hartfrequentie constant was geworden, 
hetgeen steeds het geval was 3 - 5 minuten na aanvang van een bepaalde dosis van het isoproterenol. De log dosis-respons relatie voor hel effect van het geinfundeerde isoproterenol op de hartfequentie werd bij ledere proefpersoon bepaald. Uit deze curves werd grafisch bepaald bij welke dosis van het isoproterenol een toename van de hartfrequentie van 20 slagen per minuut optrad, gerekend ten opzichte van de hartfrequentie in rust. Om de hartfrequentie in rust te bepalen, waarbij de sinusaritmie veroorzaakt door de respiratie een storende invloed kan hebben. werd de rustharfrequentie bepaald ut het gemiddelde van het langste en kortste RA interval tijdens de respiratie cyclus. Op dezelfde wijze werd de hartfrequentie bepaald tijdens de infusie met isoproterenol.

\section{- Resultaten}

De gemiddelde ( \pm S.E.M.) leeftijd van de normotensieve controle personen was: $24,8 \pm 1,3$ jaar. De gemiddelde leeftijd van de borderline hypertensieve proefpersonen was: $26,5 \pm 1,6$ jaar. Het verschil is statistisch niet significant. De lichaamsgewichten waren niet significant verschilend met $70,8 \pm 2,1 \mathrm{~kg}$ in de normotensieve controle groep tegen $76,2 \pm 4,0 \mathrm{~kg}$ in de borderline hypertensieve groep. De gemiddelde hartfrequentie in liggende houding van de normotensieve personen was $63 \pm 3 \mathrm{~min}^{-1}$, en $72 \pm 2 \mathrm{~min}^{-1}$ in de borderline hypertensieve groep. Dit verschil is statistisch significant $(p<0,05)$. In staande houding waren zowel de systolische als de diastolische bloeddruk bij vergelijking van beide groepen statistisch verschillend (voor beide waarden $p<0,001$ ) met als waarden: in de normotensieve controle groep $122 \pm 2 / 79 \pm 2 \mathrm{~mm} \mathrm{Hg}$, en in de borderline hypertensieve groep $147 \pm 2 / 96 \pm 2 \mathrm{~mm} \mathrm{Hg}$. In liggende houding was de gemiddelde bloeddruk in de controle groep $122 \pm 2 / 74 \pm 2 \mathrm{~mm} \mathrm{Hg}$ tegen $146 \pm 2 / 85 \pm 2 \mathrm{~mm} \mathrm{Hg}$ in de borderline hypertensieve groep. De verschillen zijn zowel voor de systolische als voor de diastolische bloeddrukken significant verschillend met als $p$-waarden respectievelijk $p^{\prime}<0,001$ en $p<0,01$. De benodigde dosis isoproterenol om een toename van de hartfrequentie op te roepen van 20 slagen per minuut was in de normotensieve controle groep $1,21 \pm 0,12 \mu \mathrm{gmin}^{-1}$ en in de borderline hypertensieve groep $1,09 \pm 0,11 \mu \mathrm{g} \mathrm{min}^{-1}$. Dit verschil is statistisch niet significant.

\section{- Discussie}

Bif deze studie, waarin de gevoeligheid van de proefpersonen voor isoproterenol werd bestudeerd, werd gekozen voor het criterum: een versnelling van de hartfrequentie van 20 slagen per minuut vanuit rustomstandigheden. Dit criterium is een compromis tussen hetgeen farmacologisch wenselijk is en wat vanuit het oogpunt van veiligheid haalbaar is. Immers het is niet mogelijk bij mensen de maximale chronotrope dosis te bepalen daar er in deze situatie een grote kans is op ernstige ritmestoornissen. Daarbij komt nog dat bij hogere geïnfundeerde dosis een versnelling 
van de hartfrequentie optreedt die niet veroorzaakt wordt door het rechtstreekse effect van het geinfundeerde isoproterenol op de bèta-receptoren van het hart (George et al., 1972). Dit effect komt tot stand doordat er lijdens de infusie van een hoge dosis palpitaties optreden hetgeen via gevoelens van angst bij de proefpersonen aanleiding geeft tot een verhoging van de hartfrequentie. De gevoeligheid voor isoproterenol is per individu zeer constani (George et al., 1972); daarbij komt hel effect inderdaad tot stand door stimulatie van de cardiale bèta-receptoren en niet door inhibitie van de nervus vagus zoals werd aangetoond door Cleaveland et al. (1972). Deze laatste onderzoekers bestudeerden het effect van isoproterenol op de hartfrequentie met en zonder voorafgaande loediening van atropine

Daar eerder werd aangetoond dat zowel bij normolensieve (Cleaveland et al. 1972) als bij hypertensieve mensen (London et al., 1976) de gevoeligheid voor isoproterenol afneemt met het klimmen der jaren, is hel bij een vergelijkend onderzoek van belang dat er geen leeftjjdsverschil bestaat lussen de te bestuderen groep en de controle groep. De door ons bestudeerde borderline hypertensieve groep en de normotensieve groep toonden geen significant verschil in leeftijd.

De in onze studie gevonden relatie tussen de dosis isoproterenol en de mate van polsversnelling stemmen goed overeen met de relatie die door andere onderzoekers werd gevanden (Barcrolt en Konzett, 1949; Mueller en Horwitz, 1962; Patterson et al., 1968; Gilfrich et al., 1975). Wij vonden geen significant verschil in de gevoeligheid voor isoproterenol bij vergelijking van de borderline hypertensieve met de normotensieve proefpersonen, er werden bij dit onderzoek géen argumenten gevonden die pleiten voor een toegenomen gevoeligheid van de cardiale bèta-receptoren bij de door ons bestudeerde borderlne hypertensieve proefpersonen. Dit is in overeenstemming met de resultaten van andere onderzoekers. Zo vonden Bertel et al. (1978) eenzelfde gevoeligheid voor isoproterenol bij hypertensieve mensen jonger dan 35 jaar vergeleken met normotensieven van gelike leeftijd en een afgenomen gevoeligheid van hypertensieven die ouder waren dan 35 jaar, terwijl Julius et al. (1975), London et al. (1976) en McAllister et al. (1979) vonden dat de gevoeligheid van de bèta-receptoren van hypertensieve personen afgenomen was ten opzlchte van die bij normotensieve controle personen.

Noch in de literatuur noch in ons onderzoek worden er aanwijzingen gevonden dat er bij hypertensie sprake is van een toegenomen gevoeligheid van de cardiale beta-receptoren. Dat de hogere hartfrequentie in rust van mensen met een borderline hypertensie ten opzichte van normolensieven veroorzaakt wordt doordat hun cardiale bèta-receptoren gekenmerkt worden door een toegenomen gevoeligheid voor sympathische invloeden lijkt daarom niet waarschijnlijk. 


\section{Literatuurlijst}

1. Barcroft, H., Konzett, $H$. :

On the actions of noradrenaline, adrenaline and isopropyl noradrenaline on the arterial blood pressure, heart rate and muscle flow in man. J.Physiol. $110: 194,1949$

2. Bertel, O., Buhler, F.R., Kiowsky, W.:

Isoproterenol sensitivity test in different age and renin groups of essential hypertensives.

In: Circulating catecholamines and blood pressure (ed. W.H. Birkenhäger and H.E. Falke) Bunge Scientific Publications, Utrecht 1978.

3. Cleaveland, C.R., Rango, R.E., Shand, D.G.:

A standarized isoproterenol sensitivity test.

Arch.Intern.Med. 130:47, 1972.

4. George, C.F., Conolly, M.E., Fenyvesi, T., Briant, R., Dollery, C.T.:

Intravenously administered isoproterenol sulfate dose-response curves in man.

Arch. Intern. Med. 130:361, 1972.

5. Gilfrich, H.J., Nicolescu, R.F., Rahn, K.H. :

Vergleichende Untersuchung der antihypertensiven Wirkung und der hämodynamischen Effekte von Propranolol und Oxprenolol beim Menschen.

Inn.Med. 2: 129, 1975.

6. Julius, S., Conway, J.:

Hemodynamic studies in patients with borderline blood pressure elevation.

Circulation $38: 282,1968$.

7. Julius, S., Pascual, A.V., London, R.

Role of parasympathetic inhibition in the hyperkinetic type of borderline hypertension.

Circulation $44: 413,1971$

8. Julius, S., Ellis, C.N., Pascual, A.V., Matice. M., Hansson, L., Hunyor. S.N., Sandler, L.N. :

Home blood pressure determination. Values in borderline ('labile') hypertension.

J.Amer.Med.Ass. $229: 663,1974$.

9. Julius, S. Esler, M.D., Randall, O.S.:

Role of the autonomic nervous system in mild human hypertension.

Clin.Sci.Mol.Med. 48: 243s, 1975.

10. London, G.M., Safar, M.E., Weiss, Y.A., Milliez, P.L.:

Isoproterenol sensitivity and total body clearance of propranolol in hypertensive patients.

J.Clin.Pharmacol. 16:174, 1976 
11. Lund-Johansen, $P$.

Hemodynamics in early essential hypertension.

Acta Med.Scand. Suppt. 482, p. 1, 1967.

12. McAllister JH., R.G., Love, D.V., Guthrie, P., Dominic, J.A., Kotchen, T.A. :

Peripheral beta-receptor responsiveness in patients with essential hypertension

Arch Intern Med. 139:879, 1979.

13. Mueller, P.S. Horwitz, D.:

Plasma free fatty acid and blood glucose responses to analogues of norepinephrine in man.

J.Lipid.Res. $3: 251,1962$

14. Patterson, J.W., Conolly, M.E., Davies, D.S., Dollery, C.T. : Isoprenaline resistance and the use of pressurized aerosols in asthma. Lancet II: $426,1968$.

15. Sannerstedt, R. :

Hemodynamic response to exercise in patients with arterial hypertension.

Acta Med.Scand. Suppl. 458, p. 1, 1966. 


\section{Hoofdstuk IV.3. Vergelijkend onderzoek}

naar de verandering in
bloeddruk tijdens
intraveneuze toediening van
noradrenaline bij borderline
hypertensieve en
normotensieve controle
personen

\section{- Inleiding en probleemstelling}

De oorzaak van de in relatie tot het hartminuutvolume verhoogde perifere weerstand bij mensen met hypertensie, is ondanks intensief onderzoek nog steeds niet bekend. Theoretisch is het mogelijk een aantal mechanismen aan te geven waarlangs een dergelike situatie kan ontstaan. Een verstoring in het evenwicht, dat er bij normotensieve mensen bestaat tussen de in het bloed circulerende vasoactieve stoffen die enerzijds een verhoogde tonus en anderzijds een afname van de vaattonus bewerkstelligen, lijkt indien het evenwicht verschoven is ten gunste van de vasoconstrictie veroorzakende stoffen in staat een dergelijke situatie op te roepen (Goldenberg et ai. 1948 ).

Een tweede wijze waarop een dergelijke verhoging van de weerstand in de vaten totstand zou kunnen komen is een veranderde structuur van de vaten waarbij gedacht kan worden aan morfologische veranderingen van de vaatwand, dusdanig dat de ratio lumen/vaatwanddikte veranderd is (Mendlowitz en Meyer, 1955; Folkow, 1956). In deze opvatting is de veranderde morfologie de oorzaak van de verhoogde perifere weerstand en ligt daardoor ten grondslag aan het hypertensief lijden. Een implicatie van deze opvatting is dat morfologische veranderingen ter plaatse van de vaten reeds in het begin van een hypertensief lijden aantoonbaar moeten zijn, daar immers de vaatveranderingen niet het gevolg, maar de oorzaak van de hypertensie zijn. Een derde wijze waarop een verhoging van de perifere weerstand zou kunnen ontstaan is door een afname van het aantal vaten. Verder onderzoek ter evaluatie van deze mogelijkheld likt zinvol.

Een vierde wijze waarop een verhoging van de perifere weerstand zou kunnen ontstaan is door een veranderde fysiologie van de vaatwand. waarmee een situatie bedoeld wordt wáarbij de vaatwanden sterker dam bij normotensieve mensen reageren op vasoconstrictieve invloeden. Deze gedachtengang volgend ontstaat de situatie dat een normale hoeveetheid vasoconstrictieve stoffen circulerend in de bloedstroom en een normale hoeveetheid notadrenaline afgegeven doot de sympathische zenuwuiteinden bij hypertensieve mensen een grotere toename van de perifere weerstand veroorzaken dan bij normotensieven. Een soortgelijke sluatie zou ook tot stand kunnen komen indien de bèta-receptoren gelegen in de vaatwand in mindere mate dan normaal reageren op activering. Een veranderde gevoeligheid ten opzichte van vasoconstrictieve stoffen werd 
reeds verscheidene malen beschreven bij patiènten mel bepaalde vormen van secundaire hypertensie. Voorbeelden hiervan zin de onderzoeken van Kaplan en Silah (1964) er van Hocken et al (1966). Deze onderzoekers bestudeerden de effecten van angiotensine II bij patiënten met reno-vasculaire hypertensie. Weidman ef al. (1963) en Distler et al. (1970) toonden bij patiënten met een primair aldosteronisme aan dat er bij deze patiënten sprake is van een veranderde respons bij toediening van vaso-actieve stoffen. Bij onderzoek van patienten met essentiële hypertensie vonden verschillende onderzoekers een grotere gevoeligheid van de vaten voor het vasoconstrictieve effect van noradrenaline dan bij normotensieve controle personen (Goldenberg et al. 1948; Greisman, 1952; Doyle et al. 1959: Mendowitz et al., 1965; Nestel en Ester, 1970; Tarazi en Dustan. 1973). Hiermede in tegenstelling staan de resultaten van een studie gedaan door Judson et al. (1950) die geen verschil vonden in de bloeddruk verhogende werking van noradrenaline, bij vergelijking van hypertensieve patienten met normotensieve controle personen. Opvallend is dat de onderzochte patiënten in deze studie geen reflectore daling van de hartfrequentie na toediening van noradrenaline vertoonden hetgeen doet vermoeden dat er sprake was van een speciale groep hypertensieve patienten. Met zekerheid is dat evenwel uit de ter beschikking staande gegevens niet meer te achterhalen. Met betrekking tot de onderzoeken bil mensen met essentiele hypertensie kan gesteld worden dat verreweg het grootste deal van de onderzoekers tot de conclusie kwam dal deze patiënten een toegenomen gevoeligheld hebben voor het vasoconstrictieve elfect van noradrenaline.

Bij borderline hypertensieve personen werd dit probleem slechts zeer incidenteel bestudeerd. Safar et al. (1975) die een onderzoek deden bij een groep patienten die door hen beschouwd werd als bordertine hypertensief, vonden bil deze proefpersonen juist een algenomen gevoeligheid voor noradrenaline. De proefpersonen in deze studie werden als borderline hypertensief beschouwd indien zij in de laatste 12 maanden voorafgaande aan het onderzoek bij drie willekeurige bloeddrukmetingen tenminste eenmaal een diastolische bloeddruk hadden van groter dan $90 \mathrm{~mm} \mathrm{Hg}$ en tenminste eenmaal een diastolische bloeddruk van minder dan $90 \mathrm{~mm} \mathrm{Hg}$. Dit criterium ter beoordeling van de ernst van de bloeddruk past eerder bij hel vaker gebruikte begrip 'labiele hypertensie' en verschilde daardoor van de definitie borderline hypertensie zoals wil die hanteren en die naar ons idee beler past in de definities gegeven door de W.H.O. (1958, 1962).

Hoewel de situatie in hel geval van langer bestaande hypertensie wel duidelik is geworden en de meeste onderzoekers ervan overtuigd zijn dat de gevoeligheid van de valen voor het vasoconstrictieve effect van noradrenaline groter is dan bij normotensieven. is de vraag naar dit probleem bij mensen met een borderline hypertensie nog geheel onopgelost. Om hier meer duidelijkheid over te verkijgen deden wij een onderzoek mel de vraag: Is er een verschil in de reactie van de bloeddruk op intraveneus loegediende noradrenaline bij vergeliking van borderline hypertensieve en normolensieve controle personen? 


\section{- Proefpersonen en methoden}

Uit de ter beschikking staande groep borderline hypertensieve proefpersonen en uit de normotensieve controle groep vroegen wij tekens acht willekeurig gekozen personen aan dit deel van het onderzoek te willen deelnemen, dit nadat zil volledig over de aard van het onderzoek waren geinformeerd. ledere deelnemer voldeed aan de criteria zoals beschreven in hoofdstuk IV.1. Van iedere proefpersoon werden ter gelegenheid van de noradrenaline studie de volgende parameters verkregen: ichaamsgewicht, bloeddruk na twee minuten staan en bloeddruk en hartfrequentie na twintig minuten rusten in liggende houding. De bloeddruk werd steeds door dezelfde onderzoeker gemeten aan de rechterarm, waarbij steeds gebruik werd gemaakt van dezelfde kwikmanometer. Nadat er een naald was ingebracht in een van de venen van de linker onderarm en de proefpersonen waren aangesloten aan het ECG toestel rustten zij gedurende dertig minuten in een rustige amgeving. Vervolgens werd er onder voortdurende controle van de bloeddruk en continue registratie van het ECG noradrenaline intraveneus toegediend met behulp van een infusiepomp waarbij de infusiesnelheid stapsgewijze werd verhoogd. Bij iedere stap werd het infuus zolang gegeven totdat de bloeddruk niet meer verder steeg. hetgeen steeds het geval was zes tot zeven minuten na aanvang van een bepaalde dosis van het noradrenaline. De log dosis-respons relatie voor het effect van het geinfundeerde noradrenaline op de systolische bloeddruk werd bif ledere proefpersoon bepaald. Uit deze curves werd grafisch bepaald bij welke dosis van het noradrenaline een stijging van de systolische bloeddruk optrad van $10 \mathrm{~mm} \mathrm{Hg}$. Wij kozen voor een verandering van $10 \mathrm{~mm} \mathrm{Hg}$ daar uit vooronderzoeken duidelijk was geworden dat de voor een grolere bloeddrukstiging benodigde dosis noradrenaline bil onze proefpersonen een ernstige bradycardie veroorzaakte. Aldus kwam er een compromis tot stand tussen wat farmacologisch wenselikk is en wat uit oogpunt van velligheid mogelijk is.

\section{- Resultaten}

De gemiddelde leeftijden van de door ons onderzochte groepen waren niet significant verschillend. De gemiddelde ( $t$ S. E.M.) leeftijd van de normotensieve controle groep was $24.8 \pm 1,3$ jaar tegen $26.5 \pm 1,5$ jaar in de borderline hypertensieve groep. De lichaamsgewichten waren niet significant verschillend met $70,2 \pm 2,3 \mathrm{~kg}$ in de nomotensieve controlegroep, tegen $76.7 \pm 4.2 \mathrm{~kg}$ in de borderline hypertensieve groep. In staande houding was de bloeddruk in de normotensieve groep $120 \pm 3 / 77$ $\pm 2 \mathrm{mmHg}$ tegen $144 \pm 2 / 96 \pm 2 \mathrm{mmHg}$ in de borderline hypertensieve groep, in liggende houding waren deze waarden respectievelijk $120 \pm 2 / 73 \pm 2$ en $136 \pm 2 / 90 \pm 2 \mathrm{mmHg}$. Bij onderling vergelijken zijn de verschilien in bloeddruk tussen de normotensieve controle personen en borderline hypentensieve patienten steeds significant $(p<0,001)$. De hartfrequentie in rust in de normotensieve groep was $67 \pm 4$ min $^{-1}$ en $79 \pm$ $2 \mathrm{~min}^{-1}$ in de borderline hypertensieve groep. Hel verschil is statistisch 
significant $(\rho<0.05)$. De gemiddelde dosis noradrenaline die een toename van de systolische bloeddruk van $10 \mathrm{mmHg}$ veroorzaakte was in de nomotensieve controle groep $5.13 \pm 0.42 \mu \mathrm{g} \mathrm{min}{ }^{-1}$ terwijl deze dosis in de borderline hypertensieve groep $3,50 \pm 0,57 \mathrm{~kg} \mathrm{~min}{ }^{-1}$ was. Dit verschil is statistisch significant $(p<0,05)$. De absolute afname van de hartfrequentie op het moment dat er een sliging van de systolische bloeddruk van $10 \mathrm{mmHg}$ was opgetreden, was in de normotensieve groep $11 \pm 2 \mathrm{~min}^{-1}$ en $12 \pm 2 \min ^{-1}$ in de borderline hypertensieve groep. Het verschil is statistisch niet significant. Ook de procentuele atname van de hartfrequenties, berekend door de absolute afname als procenten van de rusthartfrequentie uit te drukken, toonde geen significant verschil. De procentuele ainame van de hartfrequentie was in de normotensieve controle groep 19,6 \pm 3 en $18,7 \pm 4,4$ in de borderline hypertensieve groep.

\section{- Discussie}

De dosis noradrenaline die nodig was om eenzelfde verhoging van de systolische bloeddruk bij borderline hypertensieve en normotensieve controle personen te verkrijgen was bij de door ons bestudeerde proefpersonen kleiner in de borderline hypertensieve groep dan in de normotensieve controle groep. Door de meeste onderzoekers werd er bij patiënten met een hypertensie een verhoogde gevoeligheid voor het vasoconstrictieve effect van noradrenaline gevonden (Goldenberg et al., 1948; Greisman, 1952; Doyle et al., 1959; Mendlowitz et al., 1965; Nestel en Esler, 1970; Tarazi en Dustan, 1959). Aannemend dat deze verhoogde gevoeligheid een rol speelt in de genese van essentiele hypertensie en geen gevolg is van het hypertensief lijden passen onze bevindingen goed in het beeld van de onderzoeken gedaan bij mensen mel langer bestaande hypertensie. Immers indien de toegenomen gevoeligheid een van de oorzaken is van hypertensie moet deze toegenomen gevoeligheid reeds bestaan in de beginfase van de hypertensie en daardoor aantoonbaar zijn bij mensen met een borderline hypertensie. De patiënten die Safar et al. (1975) bestudeerden toonden een afgenomen gevoeligheid voor noradrenaline. Wat de oorzaak is van deze tegenstrijdige bevinding is niet duidelijk, mogelijk speelt het door deze onderzoekers gekozen criterium ter beoordeling of een proefpersoon al dan niet borderline hypertensief was een rol.

Waardoor er bij onze borderline hypertensieve proefpersonen een verhoogde gevoeligheid voor noradrenaline voor wat betreft het bloeddrukstigende effect tot stand is gekomen, kunnen wij niet met zekerheid aangeven. Wel lijkt het mogelik door gebruik te maken van de in de literatuur beschreven effecten van noradrenaline op de circulatie een discussie te voeren aangaande het mogelijke mechanisme dat ten grondslag ligt aan het door ons gevonden verschil bij vergelijking van normotensieve met borderline hypertensieve proefpersonen. De belangrikste plaatsen waar intraveneus toegediende noradrenaline effecten uitoefent op de circulatie zijn de vaten en het hart. Noradrenaline veroorzaakt door zijn inwerking op de arteriolen een vasoconstrictie waardoor de perifere weerstand toeneemt en de bloeddruk zal stigen. Op het hart oefent 
noradrenaline een positief inotroop en chronotroop effect uit, waardoor het hartminuutvolume toeneemt, hetgeen betekent dat er een bloeddruk verhogend effect onistaat. Recent werd er door Wagner et al. (1980) aangetoond dat het positief inotroop en chronotroop effect van noradrenaline uitsluitend tot stand komt doordat het noradrenaline de cardiale beta-receptoren stimuleert. In deze studie werd aangetoond dat adrenaline en dopamine zowel de cardiale alfa- als beta-receptoren kunnen stimuleren maar dat noradrenaline ter plaatse van het hart uitsluitend de bèta-receptoren beinvloedt. In hoofdstuk IV, 2. beschreven wij ons vergelijkend onderzoek naar de gevoeligheid van de cardiale bèta-receptoren bij borderline hypertensieve en normotensieve controle personen. Er werd geen duidelijk verschil gevonden in de gevoeligheid van deze receptoren bijvergelijking van beide groepen proefpersonen. Gezien het bovenstaande lijkt het waarschijnlijk, hoewel niet bewezen, dat het positiel inotroop en chronotroop effect bij normotensieven en borderline hypertensieve patiênten optredend tijdens intraveneuze infusie van een zelfde dosis noradrenaline van dezelfde grootte is. Immers dit effect komt bij beide groepen proefpersonen tot stand door stimulering van de cardiale bèta-receptoren, die niet verschillen in gevoeligheid voor stimulerende invloeden. Het lijkt niet waarschijnlijk dat het verschil in de reactie van de bloeddruk tijdens intraveneuze infusie van noradrenaline verklaard kan worden doordat noradrenaline in de ene groep een groter positief inotroop en chronotroop effect veroorzaakt dan in de andere groep.

Naast een direct positief inotroop en chronotroop effect op het hart heeft noradrenaline een indirect effect op het hart, waardoor de bloeddrukstijging wordt tegengewerkt. Dit tegenwerkende effect ontstaat door de baroreceptorreflex waarbij er een stimulering optreedt van de nervus vagus en er een negatief inotroop en chronotroop effect optreedt. Aan de hand van literatuurgegevens en de resultaten van onze studie zullen we dit mechanisme nader bespreken en ons met name de vraag stellen of mogelijk verschillen in het baroreceptorreflexmechanisme bijdragen aan het verschil in reactie van de bloeddruk op de toegediende noradrenaline.

Door verschillende onderzoekers werd beschreven dat de gevoeligheid van de baroreceptorreflex bij borderline hypertensieve personen verminderd zou zijn ten opzichte van normotensieven van gelijke leeftijd. Door andere onderzoekers werd deze bevinding evenwel niet bevestigd. Een afgenomen gevoeligheid werd gevonden door Takeshita et al. (1975). In deze studie werden de proefpersonen als borderline hypertensief be. schouwd indien hun bloeddruk groter was dan $150 / 90 \mathrm{~mm} \mathrm{Hg}$, terwill in de resultaten van deze studie wordt vermeld dat de gemiddelde systolische bloeddruk $160 \pm 3.5 \mathrm{~mm} \mathrm{Hg}$ was, zodat men zich kan afvragen of deze proefpersonen wel als borderline hypertensief zijn te beschotwen. Veeleer bestaat de indruk dat deze proefpersonen leden aan een meer ernstige vorm van hypertensie dan borderline hypertensie. Evenwel ook door Gribben et al. (1971) werd gevonden dat de baroreceptortellex bij borderline hypertensieve personen, waarbij deze proefpersonen bloeddrukwaarden hadden die vergelijkbaar zijn met de waarden van onze borderline hypertensieve personen, was afgenomen in gevoeligheid bil vergelijking met 
nomotensieve controle personen van dezelfde leeftijd. Door Julius (1976) werd er evenwel geen verschil gevonden in de baroreceptorreflexgevoeligheid bij vergeliking van borderline hypertensieve mel normotensieve controle personen. In het onderzoek van Bevegard et al. (1977) werd er geen verschil gevonden in de baroreceptorretlex bij vergelijking van mensen met een verhoogde bloeddruk met normotensieven. Hel lijkt wenselijk de baroreceplorrellex bij mensen met een hypertensie meer uitvoerig te onderzoeken. Te beoordelen aan de vermindering van de hartfrequentie die er bij ons onderzoek optreedt in beide groepen en waarbij er geen verschil werd gezien noch absoluut noch procentueel in de afname van de hart frequenties van beide groepen lijkt het niet waarschijnlijk dat de baroreceptorreflex van de door ons bestudeerde borderline hypertensieve proefpersonen minder actief zou zijn dan die van de normotensieven. Hoewel niet bewezen, lijkt het toch waarschijnlijk dat het negatief inotroop en chronotroop effect veroorzaakt door de baroreceptorreflex bij de door ons bestudeerde borderline hypertensieve en normotensieve controle personen van dezelfde grootte is. Het lijkt niet waarschijnlijk dat het verschil in de reactie van de bloeddruk tijdens intraveneuze infusie van noradrenaline verklaard kan worden door aan te nemen dat er een verschil is in de baroreceptorreflex bij vergelijking van borderline hypertensieven met normotensieven.

Noradrenaline veroorzaakt enerzijds ter plaatse van het hart een positief inotroop en chronotroop effect en anderzijds een negatief inotroop en chronotroop effect. waarbij het laatst genoemde effect vooral tot stand komt via de nervus vagus onder invloed van de baroreceptorreflex. Of het hartminuutvolume tijdens intraveneuze toediening van noradrenaline zal toenemen dan wel afnemen of gelijk blijven, hangt af van de grootte van beide genoemde effecten ten opzichte van elkaar. Zoals boven besproken likt het evenwel waarschijnlijk dat ongeacht de grootte van de eventueel optredende verandering in het hartminuutvolume, deze verandering indien zij optreedt, in beide groepen van dezelfde grootte zal zijn. Hoewel niet bewezen, lijkt het toch waarschijnlijk dat eventuele verandering in het hartminuutvolume tijdens intraveneuze infusie van noradrenaline er niet toe bijdraagt dat de bloeddruk van borderline hypertensieve proefpersonen op een meer uitgesproken wijze op intraveneuze toediening van noradrenaline reageet, dan die van normotensieven.

Het gevonden verschil in de benodigde dosis noradrenaline om een systolische bloeddrukstiging van $10 \mathrm{~mm} \mathrm{Hg}$ te veroorzaken, lijkt daarom gezocht te moeten worden in een veranderde gevoeligheid van de vaten.

In de studie van Goldenberg et al. (1948) waarin bij normotensieve en hypertensieve proefpersonen de effecten van intraveneus toegediend noradrenaline op de circulatie werden bestudeerd werd er tijdens deze infusie geen verandering van het hartminuutvolume gevonden. Dit zowel bij de normotensieve als bij de hypertensieve proefpersonen. Dit betekent dat voor wat betreft het hartminuutvolume gezegd kan worden dat de positief inotrope en chronotrope invloeden en de negatief inotrope en chronatrope invloeden elkaar opheffen, want alleen dan blijt het hartminuutvolume onveranderd. Hoewel het hartminuutvolume niet veranderde, komt het 
hartminuutvolume tijdens de infusie tot stand door een groter slagvolume gecombineerd mel een tragere hartfrequentie. Dit belekent dat de negatief chronotrope invloed veroorzaakt door de baroreceptorreflex het positief chronotroop effect van noradrenaline op het hart overtreft. In de studie van Goldenberg et al. (1948) werd tevens aangetoond dat de daling van de hartfrequentie inderdaad tot stand komt door activering van de nervus vagus daar de daling van de hartfrequentie te voorkomen was door atropine. De stijging van de bloeddruk tijdens de infusie van noradrenaline kwam in de studie van Goldenberg et al. (1948) tot stand door een stijging van de totale perifere weerstand daar immers het hartminuutvolume niet verandert t.o.v. het hartminuutvolume voor de infusie en ondersteunt daardoor onze theoretische beschouwing waarin wij tot de speculatie kwamen dat het verschil in reactie van de bloeddruk optredend tijdens intraveneuze infusie van noradrenaline bij vergelijk van borderline hypertensieve met normotensieve controle personen veroorzaakt wordt door een veranderde gevoeligheid van de vaten voor het bloeddruk verhogende effect van noradrenaline. Ook werd in de studie van Goldenberg et al. (1948) gevonden dat de hypertensieve proefpersonen gevoeliger voor noradrenaline waren dan de normotensieve controle personen. Te beoordelen aan onze resultaten lijkt een toegenomen gevoeligheid voor hel bloeddrukverhogende effect ook reeds bij mensen met een borderline hypertensie te bestaan. waarbij or argumenten zijn dat deze toegenomen gevoeligheid veroorzaakt wordf door een toegenomen gevoeligheid van de vaten voor noradrenaline. Hoe deze toegenomen gevoeligheid ontstaat is nog onduidelijk, maar gezien de nog jonge leeftijd van onze borderline hypertensieve proefpersonen en hun nog maar licht verhoogde bloeddruk lijken functionele veranderingen van de vaten eerder als corzaak in aanmerking te komen dan morfologische veranderingen (Friedman, 1977). 


\section{Literatuur}

1. Bevegård, S., Castentors, J., and Danielson, M. :

Carotid baroreceptor function in hypertensive patients

Scand. J clin. lab. Invest $37: 495,1977$.

2. Distler, A., Barth. G.H., Liebau, H., Vecsei, P., and Wolff, H.P.

The effect of tyramine, noradrenaline, and angiotensin on the blood pressure in hypertensive patients with aldosteronism and low plasma renin.

Europ. J. clin. Invest. $3: 196,1970$

3. Doyle, A.E., Fraser, J.R.E., and Marshall, M.J.:

Reactivity of forearm vessels to vasoconstrictor substances in hypertensive and normotensive subjects.

Clin. Sci. 18: 441, 1959

4. Folkow, B. :

Structural, myogenic, humoral and nervous factors controlling peripheral resistance.

In Hypertensive drugs, Harington, M., Ed, London and New York, Pergamon Press, 1956, p. 163.

5. Friedman, S.M. :

In Hypertension, Physiology and Treatment.

(ed. J. Genest, E. Koiw, O. Kuchel) p. 470, 1977

6. Goldenberg, M., Pines, K.L., Baldwin, E. de F., Greene, D.G., and Roh, C.H.E. :

The hemodynamic response of man to norepinephrine and epinephrine and its relation to the problem of hypertension.

Am. J. med. 5: 792, 1948.

7. Greisman, S.E.:

The reactivity of the capillary bed of the nailfold to circulating epinephrine and norepinephrine in patients with normal pressure and with essential hypertension.

J. clin. Invest. 31: 782, 1952

8. Gribben, B., Pickering, T.G. Sleight, P., and Peto, R.:

Effect of age and high blood pressure on baroreflex sensitivity in man. Circ. Res. 29:424, 1971.

9. Hocken, A.G., Kark, R.M., and Passovoy, M.

The angiotensin infusion test.

Lancet I: 5, 1966.

10. Judson, W.E., Epstein, F.H., and Wilkens, R.W.:

The comparative effects of small intravenous doses of L-norepinephrine upon arterial pressure and pulse rate in normotensive subjects and in hypertensive patients before and after thoracolumbar sympathectomy.

J. clin. Invest. 29: 1414, 1950. 
11. Jutius. $S$.

Neurogenic component in borderine hypertension.

In: The nervous system in arterial hypertension (Julius, S. and Esler. M.D., ed.), p. 301. C.C. Thomas, Springfield 1976.

12. Kaplan. N.M., and Silah, J.G.:

The effect of angiotensin II on the blood pressure in humans with hypertensive disease.

J. clin. Invest. $43: 659,1964$.

13. Mendlowitz, M. and Meyer, A. :

Effect of vasodilatation and vasoconstriction on flow pressure ratio's in the digital circulation in normotensive and hypertensive subjects.

Fed. Proc. 14: 100, 1955.

14. Mendiowitz, M., Naftchi, N.E., Gitlow, S.E., and Wolff, R.E.:

Vascular responsiveness in hypotensive and hypertensive states.

Geriatrics. 20:797, 1965.

15. Nestel, P.J., and Esler, M.D.:

Patterns of catecholamine excretion in urine in hypertension.

Circ. Res. 26-27: (suppl. Il) 75, 1970.

16. Safar, M.E., London, G.M., Welss, Y.A., Milliez, P.L.:

Vascular reactivity to norepinephrine and hemodynamic parameters in borderline hypertension.

Am. Heart J. 89:480, 1975.

17. Takeshita, A., Tanaka, S., Kuroiwa, A., and Nakamura, M. :

Reduced baroreceptor sensitivity in borderline hypertension.

Circulation. 51: 738, 1975.

18. Tarazi, R.C., and Dustan, H.P.:

Neurogenic participation in essential and renovascular hypertension assessed by acute ganglonic blockade : correlation with hemodynamic indices and intravascular volume.

Clin. Sci. $44: 197,1973$.

19. Wagner, J., Schümann, H.J., Knorr, A., Rohm, N., and Reidemeister, J.C.:

Stimulation by adrenaline and dopamine but not by noradrenaline of myocardial a -adrenoceptors mediating positive inotropic effects in human atrial preparations.

Naunyn-Schmiedeberg's Arch. Pharmacol. 312: 99. 1980

20. Weidmann, P., Endres, $P$., and Siegenthaler, $W$.:

Plasma renin activity and angiotensin pressor dose in hypertension. correlation and diagnostic implications.

Br. med. J. 3 : 154, 1963.

21. World Health organization:

Techn. Rep. 168, 1958.

22. World Health organization:

Techn. Rep. 231, 1962. 


\section{Hoofdstuk IV.4. vergelijkend onderzoek naar de activiteit van het parasympathische zenuwstelsel bij borderline hypertensieve en normotensieve controle personen}

\section{- Inleiding en probleemstelling}

Bij verschillende onderzoeken werd gevonden dat een groot deel van de jongere patiènten met een borderline hypertensie in rust onder meer gekenmerkt wordt door een toegenomen hartminuutvolume (Eich et al., 1962: Bello et al., 1965; Finkieiman et al., 1965; Lund-Johansen, 1967 ; Julius en Conway, 1968; Sannerstedt, 1969). Bij een aantal van deze onderzoeken werd tevens gevonden dat de gemiddelde hartfrequentie van borderline hypertensieve proefpersonen in rust hoger was dan van normotensieve controle personen (Lund-Johansen, 1967 ; Julius en Conway, 1968; Sannerstedt, 1969). Het mechanisme waardoor er bij borderline hypertensieve personen een toename van het hartminuutvolume en de hartfrequentie to stand komt is nog niet opgehelderd.

Emotionele hyperactiviteit (Nestel, 1969) en adreno-medullaire hypersecretie (Kuschke, 1961) zouden theoretisch via een toegenomen catecholaminen uitstorting aanleiding kunnen geven tot een hogere hartfrequentie en hartminuutvolume. In hoofdstuk IV.1 van deze studie beschreven wij de resultaten van ons onderzoek aangaande de activiteit van het sympathische zenuwstelsel bij borderline hypertensieve proefpersonen waarbij geen argumenten gevonden werden die een dergelijke hypothese ondersteunen. Frohlich et al. (1969) postuleerden dat er mogelijk sprake zou kunnen zijn van een specifieke overgevoeligheid van de bèta-adrenerge receptoren. Deze studie werd later bekritiseerd door Bourne et al (1970) die lieten zien dat de studie van Frohlich et al. niet overtuigend aantoonde dat er inderdaad sprake is van een specifieke overgevoeligheid van de béta-adrenerge receptoren. Ook in onze studie werden er geen argumenten gevonden voor een toegenomen gevoeligheid van de bèta-receptoren, zie hoofdstuk IV.2.

Een andere theoretische mogelijkheid ter verklaring van het toegenomen hartminuutvolume en de hogere hartfrequentie bif patiënten met een borderline hypertensie zou kunnen zijn dat er bij deze groep patiënten sprake is van een verminderde parasympathische activiteit. Het parasympathische deel van het autonome zenuwstelsel beinvloedt de circulatie vooral ter plaatse van het hart. Een toename van parasympathische activiteit in de situatie, dat de sympathische tonus onveranderd blijt, kan aanleiding geven tot een vermindering van de hartfrequentie en een daling van het hartminuutvolume. Andersom zal een afname van parasympathische ac- 
tiviteit een toename oproepen van de hartfrequentie en het hartminuutvoIume. Julius et al. (1971) postuleerden dat mensen met een borderline hypertensie onder meer gekenmerkt worden door een toegenomen sympathicus tonus tezamen met een afgenomen activiteit van het parasympathische zenuwstelsel. Dit idee ontstond uit de waarneming dat de hogere hartfrequentie van de borderline hypertensieve personen na toediening van propranolol weliswaar sterker daalde dan van normotensieve controle personen maar dat toch na blokkade van de sympathicus de hartfrequentie in de borderline hypertensieve groep duidelijk hoger bleef dan in de normotensieve controle groep. Pas als na vooralgaande blokkade van de sympathicus tevens de parasympathische activiteit werd geblokkeerd, door middel van atropine, werden de hartfrequenties gelijk.

Ter beoordeling van de parasympathische activiteit bepaalden wij de speekselsecretie per tijaseenheid. De hoeveelheid speeksel per minuut geproduceerd, lijkt een goede maat te zijn voor de parasympathische activiteit daar voorneen aangetoond werd dat een remming van de parasympathische activiteit aanleiding geeft tot een afname van de speekselsecretie terwijl stimulering van de parasympathische activiteit een stimulering van de speekselsecretie veroorzaakt (Emmelin, 1967; Schneyer en Schneyer, 1967). De rol van het sympathische zenuwstelsel in de regulatie van de speekselsecretie is minder duidelijk. In leder geval lijkt het sympathische zenuwstelsel in deze regulatie van veel minder belang te zijn dan het parasympathische zenuwstelsel (Emmelin, 1967; Schneyer en Schneyer, 1967).

\section{- Proefpersonen en methoden}

Uit de beschikbare proefpersonen werden ut iedere groep tien willekeurige vrijwilligers uitgenodigd aan dit deel van het onderzoek dee te nemen. Alle onderzoeken werden verricht tussen twee en vijf uur in de namiddag. Geen van de proefpersonen rookte of gebruikte een maaltijd in de twee laatste uren voorafgaande aan het onderzoek. Nadat de proefpersonen gedurende 15 minuten gerust hadden in liggende houding werden de hartfrequentie en de bloeddruk bepaald. Direct aansluitend werd de speekselsecretie gemeten. Zes cilindrische wattenrolletjes (G.D. Trolen Nr 3 ) werden in de mond aangebracht zodanig dat er in iedere wangzak een wattenrolletje werd geplaatst met daarbij tevens twee rolletjes onder de tong, met het doel alle tevoren aanwezige speeksel te verwijderen. De wattenrolletjes werden na 60 seconden verwijderd. Daarna werden er vier. te voren gewogen wattenrolletjes, aangebracht, in ledere wangzak éen. Na precies één minuut werden de wattenrolletjes verwijderd en gewogen.

$\checkmark a n$ iedere proefpersoon werd er tevens bloed afgenomen voor de bepaling van de catecholaminen in het plasma. Dit zowel in rust als tijdens inspanning op de fletsergometer bij een belasting van $75 \%$ van de tevoren bepaalde maximale capaciteit. Het protocol dat gevolgd werd, was geheel gelijk aan dat beschreven in hoofdstuk IV.1. Voor de berekening van de significantie van het verschil tussen de gemiddelden van twee groepen, werd gebruik gemaakt van de ongepaarde t-toets. 


\section{- Resultaten}

De gemiddelde ( \pm S.E.M.) hartfrequentie in de borderline hypertensieve groep was $70 \pm 2 \mathrm{~min}^{-1}$ tegen $62 \pm 3 \mathrm{~min}^{-1}$ in de normotensieve groep. Hel verschil is statistisch signiticant $(p<0,05)$. In de borderline hypertensieve groep was de bloeddruk $144 \pm 2 / 91 \pm 3 \mathrm{mmHg}$, terwijl de bloeddruk in de normotensieve controle groep $122 \pm 1 / 74 \pm 1 \mathrm{mmHg}$ bedroeg. De verschillen in zowel systolische als diastolische bloeddrukken waren statistisch significant. ( $p<0,001)$ De speekselsecretie in de borderline hypertensieve groep was $0,39 \pm 0,06 \mathrm{~g} \mathrm{~min}^{-1}$ en in de normotensieve groep 0.98 $\pm 0,06 \mathrm{~g} \mathrm{~min}^{-1}$. Het verschil tussen beide groepen is significant $(p<0,01)$. De individuele speekselsecretie bleek zeer constant te zijn dit zowel op de verschillende momenten van een dag alsook bij bepaling op verschillende dagen.

De waarden van de plasma catecholaminen worden weergegeven in Tabel 18. Bij onderling vergelijken zijn er geen statistisch significante verschillen, noch in rust noch bij inspanning. tussen de plasma catecholaminen van beide groepen.

\section{Tabel 18}

Plasma concentraties in $\mathrm{ng} / \mathrm{m} /$ van noradrenaline en adrenaline in rust (Nor $0 \%$ en Ad $0 \%$ ) en van noradrenaline en adrenaline tijdens inspanning, op een niveau van $75 \%$ van de maximale capaciteit (Nor $75 \%$ en Ad $75 \%$ ) van de normotensieve (NT) en de borderline hypertensieve proefpersonen (BHT) die participeerden in het onderzoek aangaande de parasympathische activiteit.

\begin{tabular}{|l|c|c|c|}
\hline Parameter & NT & BHT & P \\
\hline Nor $0 \%$ & $0,46 \pm 0,12$ & $0,33 \pm 0,07$ & ns \\
Nor $75 \%$ & $1,20 \pm 0,18$ & $0,80 \pm 0,10$ & ns \\
Ad $0 \%$ & $0,09 \pm 0,02$ & $0,07 \pm 0,02$ & ns \\
Ad $75 \%$ & $0,14 \pm 0,02$ & $0,17 \pm 0,03$ & ns \\
\hline
\end{tabular}

De data geven de gemiddelden van de groepen weer \pm S.E.M. $p$ geeft de significantie van hel verschil lussen de NT en de BHT. 


\section{- Discussie}

In overeenstemming met de bevindingen van andere onderzoekers (Lund-Johansen, 1967 ; Julius en Conway, 1969 ; Sannerstedt, 1969 ; Julius et al. 1971) vonden wij dat de gemiddelde hartrequentie van de borderline hypertensieve patiênten hoger was dan die van de normotensieve controle personen.

De speekselsecretie van de normotensieve controle personen is vergelijkbaar met de speekselsecretie die eerder door Reid et al. (1977) werd gevonden bij normotensieve proefpersonen. Dollery el al. (1976) vonden lets lagere waarden. $\left(0.61 \mathrm{~g} \mathrm{~min}^{-1}\right)$ De speekselsecretie van de door ons bestudeerde borderline hypertensieve proefpersonen was significant lager dan die van de normotensieve controle personen. De per tijdseenheid geproduceerde hoeveelheid speeksel wordt bepaald door het autonome zenuwstelsel (Emmelin, 1967; Scheyer en Scheyer, 1967), waarbij het parasympathische deel van het autonome zenuwstelsel het belangrijkste likt te zijn (Emmelin, 1967). Blokkade van het parasympathische systeem door atropine veroorzaakt een afname van de speekselproduktie, terwij! een toename van parasympathische activiteit veroorzaakt door elektrische stimulatie van de chorda tympani of door pilocarpine de speekselsecretie sterk doet toenemen (Emmelin, 1967 : Schneyer en Schneyer, 1967). Een toename van sympathische activiteit kan een afname van de speekselsecretie veroorzaken maar dit fenomeen treedt uitsluitend op in situaties van gestimuleerde speekselsecretie (Emmelin, 1967). Mogelijk wordt de afname van de speekselproduktie in deze situatie veroorzaakt door een verminderde doorbloeding van de speekselklieren opgeroepen door de sympathicusstimulatie. Door Heidland et al. (1973) werd gevonden dat gedurende stimulatie met pilocarpine de speekselproduktie van hypertensieve patienten minder was dan die van normotensieve controle personen. Als mogeiljke verklaring van dit fenomeen opperden deze onderzoekers, dat er mogelijk bij de hypertensieve proefpersonen sprake is van een toegenomen sympathicustonus. Naar ons idee dient evenwel ook de mogelijkheid overwogen te worden dat er bij de door hen bestudeerde hypertensieve proefpersonen, waar immers sprake is van een langer bestaande hypertensie, reeds veranderingen ter plaatse van de vaten zijn opgetreden, waardoor de doorbloeding van de speekselklieren niet meer zo optimaal is als bi] normotensieve controle personen. In de literatuur worden geen argumenten gevonden voor de veronderstelling dat er in rust, bij niet gestimuleerde speekselklieren een vermindering van de speekselproduktle optreedt onder sympathicusstimulatie (Emmelin, 1967; Schneyer en Schneyer, 1967). Bij de meeste dieronderzoeken wordt er zelfs een kleine en tijdelijke toename van de speekselsecretie gevonden optredend na sympathicusstimulatie (Emmelin, 1967: Schneyer en Schneyer, 1967: Gjörstrup, 1977 ; Orstravik, 1978). Voorzover ons bekend werd het effect van sympathicusstimulatie op de basale speekselsecretie bil de mens nog niet systematisch bestudeerd. Reid et al. (1977) vonden geen verschil tussen de basale speekselsecretie van patiënten met een tetra-plegie, bif wie sympathische invloeden geheel geblokkeerd waren, en die van gezonde controle personen. Beide bestudeerde groepen lieten een daling van de speekselproduktie zien na toediening van clonidine. 
De verminderde speekselsecretie in de borderline hypertensieve groep proefpersonen in onze studie likt veroorzaakt te kunnen worden helzij door een afgenomen parasympathische activiteit hetzij door een toegenomen sympathicustonus in de borderline hypertensieve groep ten opzichte van de normotensieve controle groep. De laatstgenoemde verklaring lijki op grond van de beschikbare literatuurgegevens minder waarschijnlijk.

Onze bevinding is in overeenstemming met de hypothese van Juilus et al (1971). De plasma catecholaminen die gevonden werden bij onze proefpersonen wijzen niet in de richting van een verschil in sympathische activiteit. Met zekerheid is evenwel een verschil in sympathische activiteit niel vit te sluiten, daar er nog steeds de mogelijkheid blift bestaan dat ondanks gelijke plasma catecholaminenspiegels er verschillen zouden kunnen zijn in de catecholamine concentraties ter plaatse van de receptoren. Tevens is de mogelijkheid nog aanwezig dat de receptoren een verschillende gevoeligheid bezitten. Mocht inderdaad een toegenomen sympathische activiteit een rol spelen dan zou men, op grond van dierstudies (Emmelin, 1967: Schneyer en Schneyer, 1967 ; Gjörstrup. 1977 ; Orstravik, 1978), eerder een toename van de speekselsecretie mogen verwachten. Dat een veranderde sympathische activiteit het verschil in speekselproduktie zou veroorzaken lijkt minder waarschijnlijk.

Verder onderzoek dient verricht te worden naar welk deel van het autonome zenuwstelsel verantwoordelijk is voor de verminderde speekselsecretie bij mensen met een borderline hypertensie. Een belangrijke conclusie lijkt reeds nu gerechtvaardigd, namelijk dat er in een zeer vroege fase van een hypertensief lijden een verandering aantoonbaar is in de functie van het autonome zenuwstelsel, waarbij het waarschijnlijk lijkt dat er sprake is van een verminderde parasympathische activiteit. 


\section{Literatuur}

1. Bello, C.T., Sevy, R.W., Harakal, C.:

Varying hemodynamic patterns in essential hypertension.

Amer. J. med. Sci. 250: 24, 1965.

2. Bourne, H.R., Thomson, P.D., Melmon, K.L. :

Diagnosis and treatment of beta-adrenergic receptor hyperresponsiveness: A clinical appraisal.

Arch. Intern. Med. (Chicago) 125: 1063, 1970.

3. Dollery, C.T., Davies, D.S., Draffan, G.H., Dargie, H.J., Dean, C.R., Reid, J.L., Clare, R.A., and Murray, S.

Clinical pharmacology and pharmacokinetics of clonidine.

Clin. Pharmacol. Ther. 19: 11. 1976.

4. Eich, R.H., Peters, R.J., Cuddy, R.P., Smulyan, H., Lyons, R.H:

The hemodynamics in labile hypertension.

Amer. Heart J. 63: 188, 1962.

5. Emmelin, N. in:

Handbook of Physiology, Section 6, vol. Il (ed. C.F. Code), Am. Physiol. Soc. Washington, 1967, 595

6. Finkielman, S., Worcel, M., Agrest, A. :

Hemodynamic patterns in essential hypertension.

Circulation. 31:356, 1965

7. Frohlich, E.D., Tarazi, R.C., Dustan, H.P.:

Hyperdynamic $\beta$-adrenergic circulatory state: Increased $\beta$-receptor responsiveness.

Arch. Intern. Med. (Chicago) 123: 1, 1969.

8. Gjörstrup, P.:

Effects of sympathetic nerve stimulation in the presence of a slow parasympathetic secretion in the parotid and submaxillary glands of the rabbit.

Acta Physiol. Scand. 101:211, 1977.

9. Heidland. A., Hennemann, H., Lenhart, F.P., Wigand, M. E., Nowotny. H.:

Klinische Aspekte der Hypertonie

Therapiewoche. 45: 4253, 1973

10. Julius, S., Conway, J.:

Hemodynamic studies in patients with borderline blood pressure elevation.

Circulation. $38: 282,1968$.

11. Julius, S., Pascual, A.V., London, R.:

Role of parasympathetic inhibition in the hyperkinetic type of borderline hypertension.

Circulation. $44: 413,1971$. 
12. Kuschke, H.J.:

Untersuchungen uber den Erregungszustand des Sympathischen Nervensystems und des Nebennierenmarkes bei Kardiovascularen Erkrankungen.

Arch. Kreislautforsch. $36: 104,1961$.

13. Lund-Johansen, P. :

Hemodynamics in early essential hypertension.

Acta Med. Scand. (Suppl 482): 1, 1967.

14. Nestel, P.J.:

Blood pressure and catecholamine excretion after mental stress in labile hypertension.

Lancet 1: 692, 1969.

15. Orstravik, T.B.

The distribution and secretion of kallikrein in some exocrine organs of the rat.

Acta Physiol. Scand. 104: 431, 1978.

16. Reid, J.L., Wing. L.M.H., Mathias, C.J., Frankel, H.L., Neill, E. :

The central hypotensive effect of clonidine. Studies in tetraplegic subjects.

Cin. Pharmacol. Ther, 21:375, 1977.

17. Samerstedt, $R$.

Hemodynamic findings at rest and during exercise in mild arterial hypertension.

Amer J. Med. Sci. 258: 70, 1969

18. Schneyer, L.H., Schneyer, C.A. in:

Handbook of Physiology, Section 6, vol. II (ed. C.F. Code), Am. Physiol. Soc, Washington, 1967, 497. 


\section{Samenvatting en slotbeschouwing}

In het eerste hoofdstuk van dit proefschrift wordt uiteengezet waarom bij dit onderzoek naar de genese van essentiële hypertensie gekozen werd voor een vergelijkend onderzoek naar de activiteit van het autonome zenuwstelsel van mensen met een borderline hypertensie en normotensieve controle personen. Gememoreerd wordt dat het autonome zenuwstelsel een grote rol speelt in de regulatie van de bloeddruk en dat het autonome zenuwstelsel bij alle vormen van experimentele hypertensie participeert in de ontwikkeling van de bloeddrukverhoging. Om deze redenen lijkt het interessant te onderzoeken of het autonome zenuwstelsel een rol speelt in de genese van essentiële hypertensie. Tevens wordt in dit eerste hoofdstuk aangegeven uit wetke hoofdstukken het proefschrift bestaat en waarom deze indeling gekozen werd.

In hoofdstuk II wordt aandacht besteed aan de betekenis van hypertensie als menselijk fenomeen. Een dergelijke beschrijving zal de relevantie van een onderzoek naar de genese van essentielle hypertensie ten goede komen. Onder meer wordt in dil hoofdstuk aandacht gegeven aan de definitie van hypertensie, de incidentie van hypertensie, causale factoren die een rol spelen in de genese van essentiële hypertensle, de kwalificatie van hypertensie naar ernst en naar etiologie en de betekenis van hypertensie als risicofactor. Aan de hand van literatuurgegevens wordt aangetoond dat behandeling van hypertensieve patienten zinvol is, daar door behandeling de prognose van hypertensieve patienten verbetert. Daar het onderzoek naar de genese van essentiële hypertensie verticht werd met borderline hypertensieve proefpersonen wordt aan hel einde van dit hoofdstuk een speciale paragraaf gewijd aan het fenomeen borderine hypertensie.

In hoofdstuk III wordt de relatie tussen het autonome zenuwstelsel en de bloeddrukregulatie beschreven. Speciale aandacht wordt besteed aan de autonome reflexboog en aan het efferente deel van het autonome zenuwstelsel voor zover dat van belang is voor de circulatie. In dit hoofdstuk word: ingegaan op de catecholaminen noradrenaline en adrenaline en op hun metabolisme. Het hoofdstuk wordt afgesloten met een beschrijuing van de effecten die het autonome zenuwstelsel kan uitoefenen op de circulatie en een theoretische beschouwing over hoe een stoornis van het autonome zenuwstelsel hypertensie zou kunnen veroorzaken.

Hoofdstuk IV valt uiteen in een aantal afzonderlijke delen voorafgegaan door een inleiding waarin de onderlinge relatie van de atzonderlike onderzoeken en hun betekenis wordt beschreven.

In hoofdstuk IV.1 wordt een vergelijkend onderzoek beschreven naar de activiteit van het sympathische zenuwstelsel en het renine systeem bij 25 borderline hypertensieve en 25 normotensieve controle personen. Bij aanvang van het onderzaek waren alle proefpersonen tussen de 18 en 30 jaar oud. Als normotensief werden proefpersonen beschouwd als hun 
bloeddruk in staande houding gemeten lager dan of gelik was aan $125 / 85 \mathrm{~mm} \mathrm{Hg}$, terwill proefpersonen als borderline hypertensief werden beschouwd indien hun bloeddruk in dezelfde houding gemelen groter dan of gelijk was aan $140 / 90 \mathrm{~mm} \mathrm{Hg} \mathrm{maar} \mathrm{lager} \mathrm{dan} 160 / 100 \mathrm{~mm} \mathrm{Hg}$. Daar wij geinteresseerd waren in de ontwikkeling van de bloeddruk in de tijd in relatie tot de activiteit van het sympathische zenuwstelsel en het renine systeem werden de proefpersoner gedurende twee jaar vervolgd waarbij zij bij aanvang van de studie en na éen en na twee jaar onderzocht werden. Onder meer werd bil ieder onderzoek van iedere proefpersoon de uitscheiding in de 24-uurs urine bepaald van natrium, VMA, noradrenaline en adrenaline. Van ledere proefpersoon werd bij jeder onderzoek de maximale werkcapaciteit op de fietsergometer bepaald. Vijf tot veertien dagen hierna werden de deelnemers aan het onderzoek opnieuw onderzocht. Na een rustperiode van 30 minuten in liggende houding werden de volgende paramelers verkregen: hartfrequentie, bloeddruk, plasma catecholaminen; plasma renine activiteit en plasma renine concentratie. Hierna fietsten de proefpersonen gedurende 5 minuten met een belasting van $50 \%$ van hun maximale werkcapaciteit onmiddellik gevolgd door een periode van 5 minuten met een inspanning op een niveau van $75 \%$ van hun maximale werkcapaciteit. Aan het einde van deze inspanningsperiode werden dezelfde parameters gemeten als aan het einde van de rustperiode. Het plasma noradrenaline en adrenaline gehalte werd bepaald met een radioenzymatische methode. De plasma renine activiteit en plasma renine concentratie werden gemeten met een radio - immunologische techniek.

Met betrekking tot het sympathische zenuwstelsel en het renine systeem waren de belangrijkste bevindingen als volgt: Bil geen van de drie onderzoeken werden er verschillen tussen beide groepen gevonden in de uitscheiding in de 24-uurs urine van natrium, VMA, noradrenaline en adrenaline. Noch in rust noch bij inspanning waren er verschillen tussen de borderline hypertensieve en de normotensieve controle groep in de plasma catecholaminen. De plasma renine activiteit en plasma renine concentratie waren vrijwel identiek in beide groepen. Tijdens het vervolgonderzoek werden twee oorspronkelijk borderine hypertensieve personen hypertensief (bloeddruk in staande positie groter dan $160 / 100 \mathrm{~mm} \mathrm{Hg}$ ). De plasma catecholaminen en de plasma renine activiteit en renine concentratie van deze twee proefpersonen verschilden niet van die van de overige deelnemers aan het onderzoek. Wat betreft de hemodynamische parameters tijdens het onderzoek verkregen, lijkt ons één van de interessantste bevindingen dat de rusthartfrequentie van de borderline hypertensieve steeds hoger was dan die van de normotensieve controle personen terwij] de hartfrequenties tijdens maximale inspanning niet meer verschilden.

De bevindingen gedaan bij dit onderzoek werden besproken in relatie tot de beschikbare literatutr. Geconcludeerd wordt da: het niet waarschijnlijk lijkt dat een toegenomen sympathische activiteit een belangrijke rol speelt in de genese van essentiële hypertensie.

In hoofdstuk. IV.2 wordt een vergelijkend onderzoek beschreven naar de verandering in hartfrequentie tijdens intraveneuze toediening van isoproterenol bij 8 borderline hypertensieve en 8 normolensieve controle 
personen. Doel van dit onderzoek was te onderzoeken of de hogere hartfrequentie in rust van borderline hypertensieve ten opzichte van normotensieve personen, zoals die door ons en door verschillende andere onderzoekers werd gevonden, verklaard kan worden door een grotere gevoeligheid van de cardiale bèta-adrenerge receptoren bij mensen met een borderline hypertensie voor sympathische invloeden. Door dosis werkings-curves te maken van het effect van isoproterenol op de hartirequentie was hel mogellik de gemiddelde dosis per groep te berekenen die nodig was om een stigging van de hartfrequentie van 20 slagen per minuul te verkrijgen ten opzichte van de rusthartfrequentie. De benodigde dosis was in de borderline hypertensieve groep even groot als in de normotensieve controle groep. De resultaten werden besproken in relatie tot de literatuurgegevens betreffende dit onderzoeksgebied. Geconcludeerd werd dat de hogere hartfrequentie in rust van borderline hypertensieven ten opzichte van normotensieve personen niet veroorzaakt wordt door een grotere gevoeligheid van de cardiale bèta-receptoren bij borderline hypertensieve mensen.

In hoofdstuk IV.3 wordt een vergelikend onderzoek beschreven naar de verandering in bloeddruk tijdens intraveneuze toediening van noradrenaline bij 8 borderline hypertensieve en 8 normotensieve controle personen. Doel van dit onderzoek was na te gaan of mensen met een borderline hypertensie gevoeliger zijn voor het bloeddrukverhogende effect van noradrenaline dan normotensieven. Een grotere gevoeligheid voor het bloeddrukverhogende effect van noradrenaline dat tot stand komt door de alfa-sympathomimetische activiteit van het noradrenaline op de vaten zou kunnen verklaren waarom borderline hypertensieven, hoewel hun plasma noradrenaline concentratie niet hoger is dan die van normotensieven toch een hogere bloeddruk hebben. Door dosis-werkingscurves te maken van het effect van intraveneus toegediende noradrenaline op de systolische bloeddruk was het mogelijk de gemiddelde benodigde dosis noradrenaline te berekenen per groep die nodig was om een stijging van de systolische bloeddruk van $10 \mathrm{~mm} \mathrm{Hg}$ te verkrijgen ten opzichte van de systolische bloeddruk in rust. Deze dosis was kleiner in de borderline hypertensieve groep. Deze bevinding werd bediscussieerd in relatie tot de literatuurgegevens. Geconcludeerd werd dat mensen met een borderline hypertensie gevoeliger zijn voor het bloeddrukverhogende effect van noradrenaline dan normotensieven

In hoofdstuk IV.4 wordt een vergelijkend onderzoek beschreven naar de activiteit van het parasympathische zenuwstelsel bij 10 borderline hypertensieve en 10 normotensieve controte personen. Een afgenomen parasympathische activiteit zou de hogere hartfrequentie van borderline hyper* tensieven ten opzichte van normotensieve personen in rust kunnen verklaren. Ter beoordeling van de activiteit van het parasympathische zenuwstelsel werd de speekselsecretie per tijdseenheid gemeten. In dit hoofdstuk werd de relatie tussen de speekselsecretie en hel parasympathische zenuwstelsel besproken. De speekselsecretie van borderline hypertensieven was significant minder dan die van normotensieve personen. De 
betekenis van deze bevinding werd besproken. Geconcludeerd werd dat er in de beginfase van een essentiele hypertensie sprake is van een verminderde parasympathische activiteit.

Resumerend: Bil dit vergelijkend onderzoek betreffende het autonome zenuwstelsel en de bloeddrukregulatie bif borderline hypertensieve en normotensieve controle personen zijn de belangrijkste bevindingen de volgende:

- Er werden geen argumenten gevonden die de hypothese ondersteunen dat er bij mensen met een borderline hypertensie sprake is van een toegenomen activiteit van het sympathische zenuwstelsel en/of hel renine systeem.

- De gevoeligheid van de cardiale bèta-adrenerge receptoren voor sympathische invloeden van mensen met een borderline hypertensie lijkt niet te zijn toegenomen vergeleken met die van normolensieve personen.

- Borderline hypertensieve mensen zijn gevoeliger voor het bloeddrukverhogende effect van noradrenaline.

- Aanwijzingen werden gevonden dat de activiteit van het parasympathische deel van het autonome zenuwstelsel bij mensen met een borderline hypertensie minder actief is dan bij mensen met een normale bloeddruk.

De hemodynamische verschillen in de circulatie van borderline hypertensieve mensen ten opzichte van normotensieve personen, te weten: de hogere bloeddruk en de toegenomen hartfrequentie in rust, waarbij hel verschil in hartfrequentie niet meer word teruggevonden tijdens inspanning op maximale werkcapaciteit kunnen met deze bevindingen verklaard worden. De hogere hartfrequentie in rust van borderline hypertensieve ten opzichte van normotensieve personen kan niet verklaard worden door een grotere sympathische activiteit of een toegenomen gevoeligheid van de cardiale bela-adrenerge receptoren voor sympathische invloeden, maar door de in rust gevonden afgenomen parasympathische activiteit var borderline hypertensieve ten opzichte van normotensieve personen. Dat het verschil in hartfrequentie tijdens inspanning op maximale werkcapaciteit verdwijnt, is in overeenstemming met deze hypothese daar tijdens maximale inspanning de invloed van het parasympathische zenuwstelsel opgehaven is.

De hogere bloeddruk van de borderline hypertensieven kan verklaard worden uit de toegenomen gevoeligheid van de vaten voor het vasoconstrictieve effect van noradrenaline. Hierdoor is te verklaren waarom de bloeddruk bil de borderline hypertensieve personen verhoogd is ten opzichte van die bij normotensleven, hoewel de plasma noradrenaline splegels noch in rust noch bij inspanning verschillend zijn. Voor een uitvoerige discussie van onze bevindingen wordt verwezen naar de desbetreffende discussies bij de verschillende onderzoeken beschreven in hoofdstuk IV van dit proefschrift. Wat de onderliggende mechanismen zijn waardoor de toegenomen gevoeligheid van de vaten en de afgenomen parasympathische activiteit tot stand komt bij mensen met een borderline hypertensie is nog onduidelijk. Verder onderzoek zal met enthousiasme ter hand worden genomen. 


\section{Summary and conclusive remarks}

The present thesis is an investigation into the role of the autonomic nervous system in the genesis of essential hypertension. In the first chapter the reason of comparing the autonomic nervous system activity in bordertine hypertensive and normotensive control subjects is outlined. A review is given of the important role of the autonomic nervous system in the regulation of blood pressure and furthermore the reader is reminded of the fact that in all forms of experimental hypertension the autonomic nervous system is involved in the development of the hypertension. Finally, in this first chapter the structure of the present thesis is delineated. The reasons for chosing this structure are explained.

Chapter II deals with hypertension as a human phenomenon. Such a description may indicate the relevance of research into the genesis of essential hypertension. Among other things, attention is paid to the definition of hypertension, the incidence of hypertension, causal factors playing a role in the genesis of essential hypertension. classification of hypertension according to severity and etiology and hypertension as a risk-factor. Evidence from literature is cited to prove that treatment of hypertensive patients improves their prognosis. Because the present investigation into the genesis of essential hypertension was done in borderline hypertensive subjects, the last paragraph of this chapter is devoted to borderline hypertension.

In chapter III a description is given of the relation between the autonomic nervous system and blood pressure control. Special attention is paid to the autonomic reflex-arc and the efferent part of the autonomic nervous system as far as it is important for the circulation. Furthermore, attention is paid to the catecholamines noradrenaline and adrenaline and their metabolism. The chapter is concluded by giving a description of the effects that the autonomic nervous system may exert on the circulation and by considering how a disorder of the autonomic nervous system may lead to hypertension.

Chapter IV is divided into a number of separate parts. In the introduction the interrelations between the different investigations are delineated.

Chapter IV.1 describes a comparative investigation into the activity of the sympathetic nervous system and the renin system in 25 borderline hypertensives and 25 normotensive control-subjects. At the start of the study all subjects were between 18 and 30 years old. Subjects were regarded as normotensive if their blood pressure, measured in the upright position, was equal to or lower than $125 / 85 \mathrm{~mm} \mathrm{Hg}$. If blood pressure was higher than or equal to $140 / 90 \mathrm{~mm} \mathrm{Hg}$ but lower than $160 / 100 \mathrm{~mm} \mathrm{Hg}$ subjects were admitted to the group of borderline hypertensive subjects. Since we were interested in the evolution of blood pressure in relation to the activity of the sympathetic nervous system and the renin system, a two-year follow-up 
study was done for which all subjects were inspected at the start of the investigation and one and two years later. Among other things we determined excretion of sodum. VMA, noradrenaline and adrenaline in a 24 -hour urine sample of each subject. The maximal work-capacity of each subject was determined. using a bicycle-ergometer. Five to fourteen days later the subjects were inspected again. After a 30 min. resting period in the supine position we measured heart rate blood pressure, plasma catecholamine levels, plasma renin activity and plasma renin concentration. Thereafter subjects exercised on the bicycle-ergometer at $50 \%$ of their maximal work-capacity for 5 min., which was followed immediately by a 5 min. period at which they exercised at $75 \%$ of their maximal work-capacity. At the end of this latter period the parameters which were measured after the resting period were obtained again. Levels of noradrenaline and adrenaline in plasma were determined, using a radio-enzymatic method. Plasma renin activity and plasma renin concentration were measured with a radioimmunoassay.

With regard to the sympathetic nervous system the most important findings may be summarized as follows; at none of the three inspections there were differences between the two groups with respect to the excretion of sodium. VMA, noradrenaline and adrenaline in urine in a 24 hour period. Neither at rest, nor during exercise there were differences in plasma-levels of catecholamines between the groups of nomotensive and borderline hypertensive subjects. Plasma renin activity and plasma renin concentration were almost identical in the two groups. During the course of the study two subjects from the borderline hypertensive group developed hypertension (blood pressure in the upright position higher than $160 / 100 \mathrm{~mm} \mathrm{Hg}$ ). Plasma catecholamine-levels and plasma renin activity and concentration in these iwo subjects were not different from those of the other subjects. The most interesting result from the hemodynamic measurements in this investigation is the observation that the heart rate of borderline hypertensive subjects was always higher than that of the normotensive subjects. except during exercise at maximal work-capacity. when it was equal in the two groups.

The results from the present study are discussed in relation to those in the literature. It is concluded that an increased sympathetic nervous activity does probably not play an important role in the genesis of essential hypertension.

Chapter IV.2 contains an investigation in which the effects of intravenously administered isoproterenol on heart rate in 8 borderline hypertensive and 8 normotensive subjects were compared. The aim of the study was to investigate whether the higher resting-heart rate in borderline hypertensives, as compared to normotensive subjects, as found by us as well as other investigators, may be explained by a greater sensitivity of the cardiac beta-adrenoceptors for sympathetic influences in the borderline hypertensive subjects. By constructing dose-response curves for the effects of isoproterenol on heart rate, it was possible to calculate the mean dose that was needed to increase heart rate by 20 beats per minute for the two groups. This dose was equal in the iwo groups. Results are discussed in 
relation to literature. It is concluded that the higher resting-heart rate in borderline hypertensive subjects as compared to normotensive controlsubjects is not caused by an increased sensitivity of the cardiac beta-adrenoceptors in borderline hypertensives.

In chapter IV.3 results are described from a comparative study of the blood pressure changes during intravenous administration of noradrenaline in 8 borderline hypertensives and 8 normotensive control-subjects. The aim of the investigation was to study, whether borderline hypertensive subjects are more sensitive to the blood pressure increasing effect of noradrenaline than normotensives. An increased sensitivity for this effect, which derives from an alpha-sympathomimetic action of noradrenaline on the blood vesseis, might explain why borderline hypertensive subjects have an increased blood pressure in spite of normal plasma noradrenaline levels as compared to those in normotensive control-subjects. From dose-response curves of the effects of intravenously administered noradrenaline on systolic blood pressure th was possible to calculate the mean dose of noradrenaline which was needed to increase systolic blood pressure by $10 \mathrm{~mm} \mathrm{Hg}$ above resting values in the two groups. This dose was smaller in the borderline hypertensive group than in the group of normotensive subjects. This result is discussed in relation to reports in literature. It is concluded that borderline hypertensive subjects are more sensitive to the blood pressure increasing effect of noradrenaine than normotensives.

Chapter IV.4 contains results from a comparative study of the activity of the parasympathetic nervous system in 10 borderline hypertensive and 10 normotensive control-subjects. Differences in this parameter might explain the higher resting-heart rate in borderline hypertensives as compared to normotensive subjects. As a measure for parasympathetic nervous activity the saliva-flow was taken. In this chapter the relation between saliva-flow and parasympathetic nervous activity is described. Saliva-flow in borderline hypertensive subjects was significantly less than in normotensive subjects. It is concluded that in the early phase of essential hypertension there is a decrease in parasympathetic nervous activity.

The most important results from the present investigation, in which a comparison between the autonomic nervous system and blood pressure control in normotensive and borderline hypertensive subjects was made. may be summarized as follows

- No evidence was found in favour of the hypothesis that borderline hypertensives have an increased activity of the sympathetic nervous system and/or the renin system.

- The cardiac beta-adrenoceptors in normotensive and borderline hypertensive subjects are equally sensitive.

- Borderline hypertensive subjects have an increased sensitivity towards the blood pressure increasing effect of noradrenaline.

- Evidence was found for a decreased activity of the parasympathetic nervous system in borderline hypertensive subjects, as compared to normotensives. 
These findings may explain the hemodynamic differences between borderline hypertensive and normotensive subjects, consisting of increased resting-values for blood pressure and heart rate. whereas the difference in heart rate beiween the two groups disappears when subjects exercise at maximal work-capacity. The increased resting heart rate in borderline hypertensives as compared to that in normotensive control-subjects cannot be explained on the basis of increased sympathetic nervous activity or increased sensitivity of the cardiac beta-adrenoceptors towards sympathetic influences, but rather by the decrease in parasympathetic nervous activity that we found in resting borderline hypertensive subjects. compared to normotensive control subjects. In agreement with this hypothesis is the observation that the difference in heart rate in the two groups disappears when subjects exercise at maximal work-capacity, because then the influence of the parasympathetic nervous system is abolished.

The increased blood pressure in borderline hypertensives may be explained by the increased sensitivity of the blood vessels with regard to the vasoconstrictive effect of noradrenaline. This may explain why the blood pressure in borderline hypertensive subjects is increased as compared to that in normotensive subjects, in spite of equal plasma levels of noradrenaline at rest and during exercise. We discussed our results extensively in conjunction with the separate investigations in chapter IV of this thesis. The mechanisms underlying the establishment of the increased vascular sensitivity and the diminished parasympathetic activity in borderline hypertensive subjects are still not elucidated. Further investigations will be carried out enthousiastically. 


\section{Dankwoord}

Dit proefschrift moet gezien worden als een rapportage van een onderzoek dat mogelijk werd door het enthousiasme en de inspanning van velen. ledereen die zijn bijdrage leverde bij het tot stand komen dank ik van harte. In het bijzonder dank ik Prof. Dr. K.H. Rahn voor het vertrouwen dat hij in mij stelde door mij deel uit te laten maken van de capaciteitsgroep farmacologie waar ik onder zijn leiding dit onderzoek mocht uitvoeren.

Ik dank beide referenten, Prof. Dr. R.A.P. Koene en Prof. Dr. H.A.J. Struyker Boudier, voor hun bereidheid het manuscript te lezen en voor hun waardevolle commentaren.

Ik dank mijn collega's voor hun bemoedigingen en adviezen. Speciaal wil ik dank betuigen aan Ir. M. Schols, die de drijvende kracht van de organisatie was en mij steeds op onnavolgbare wijze assisteerde bij de verschillende onderzoeken. De 'trouw' van de proefpersonen is vooral door zijn voortdurend enthousiasme en zijn inzet zo groot geweest.

Mw. A. Lippinkhof typte het manuscript op de haar eigen uitmuntende wijze.

De dames en heren van het farmacologisch laboratorium van de Rijksuniversiteit Limburg en speciaal de dames $m w$. G. Bost, mw. M. Daamen, mw. $M$. Fuss, $m w$. A. Pisters en de heer $L$. Baars dank ik van harte voor het vele werk dat zij verzet hebben.

Tot slot een speciaal woord van dank voor de proefpersonen die trouw, ook na drie jaar, aan de vele onderzoeken bleven deelnemen. Slechts éen van de vijftig liet het afweten. Het geringe aantal uitvallers mag uniek genoemd worden. 


\section{Curriculum vitae}

J.W. Henquet werd geboren te Maastricht.

In 1960 behaalde hij het eindexamen van de HBS b te Roermond.

Hij studeerde geneeskunde aan de medische faculteiten te Utrecht en Nijmegen en behaalde in 1968 het artsexamen te Nijmegen.

Hierna was hij twee jaar werkzaam als artsassistent op het streek-en ziekenhuislaboratorium voor bacteriologie-serologie en de bloedtransfusiedienst van het ziekenhuis St.-Annadal te Maastricht. (Hoofd: Dr. G. Kok.)

Daarna kreeg hij zijn opleiding tot internist op de interne afdeling van het ziekenhuis St-Annadal. (Hoofd: Dr. J. Coenegracht).

Op dezelfde afdeling van dit ziekenhuis was hij twee jaar werkzaam als chef de clinique op de interne afdeling.

Vanaf oktober 1976 werkt hij in de capaciteitsgroep Farmacologie van de Rijksuniversiteit Limburg (Voorzitter: Prof. Dr. K.H. Rahn) en als internist op de afdeling interne geneeskunde van het ziekenhuis St.-Annadal te Maastricht. 
